Andrews University

Digital Commons @ Andrews University

1977

\title{
Self-Concept Patterns of Inadequate and Adequate Adult Readers
}

Anna Homenchuk Klimes

Follow this and additional works at: https://digitalcommons.andrews.edu/dissertations

Part of the Education Commons

\section{Recommended Citation}

Klimes, Anna Homenchuk, "Self-Concept Patterns of Inadequate and Adequate Adult Readers" (1977). Dissertations. 1698.

https://digitalcommons.andrews.edu/dissertations/1698

https://dx.doi.org/10.32597/dissertations/1698

This Dissertation is brought to you for free and open access by the Graduate Research at Digital Commons @ Andrews University. It has been accepted for inclusion in Dissertations by an authorized administrator of Digital Commons@ Andrews University. For more information, please contact repository@andrews.edu. 
Andrews University

School of Graduate Studies

SELF-CONCEPT PATTERNS OF

INADEQUATE AND ADEQUATE ADULT READERS

\author{
A Dissertation \\ Presented in Partial Fulfillment \\ of the Requirements for the Degree \\ Doctor of Education
}

by

Anna Klines

July 1977 


\title{
SELF-CONCEPT PATTERNS OF INADEQUATE AND ADEQUATE ADULT READERS
}

\author{
A dissertation \\ presented in partial fulfillment \\ of the requirements for the degree \\ Doctor of Education
}

by

Anna Klimes

APPROVAL BY THE COMITTEE:

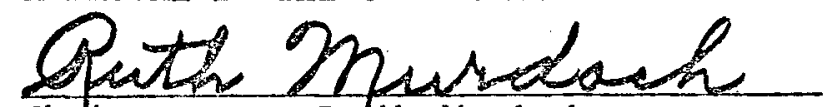

Chatirperson: R. (i... Murdoch

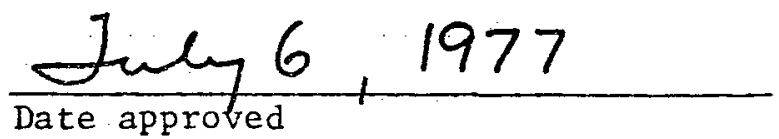

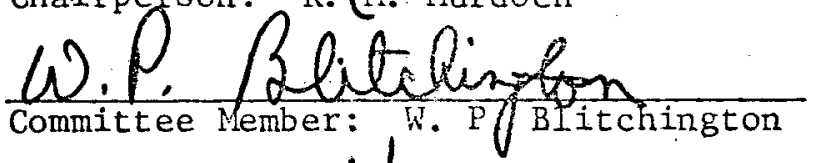

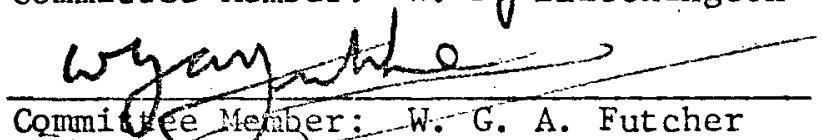

Commi He Mgriber:W.-W. A. Futcher

Comittge Member: M. J. Merchant

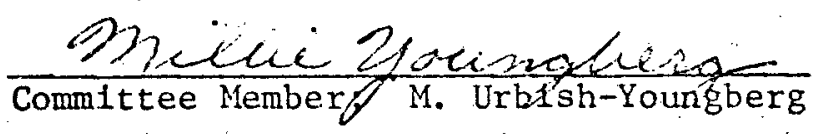
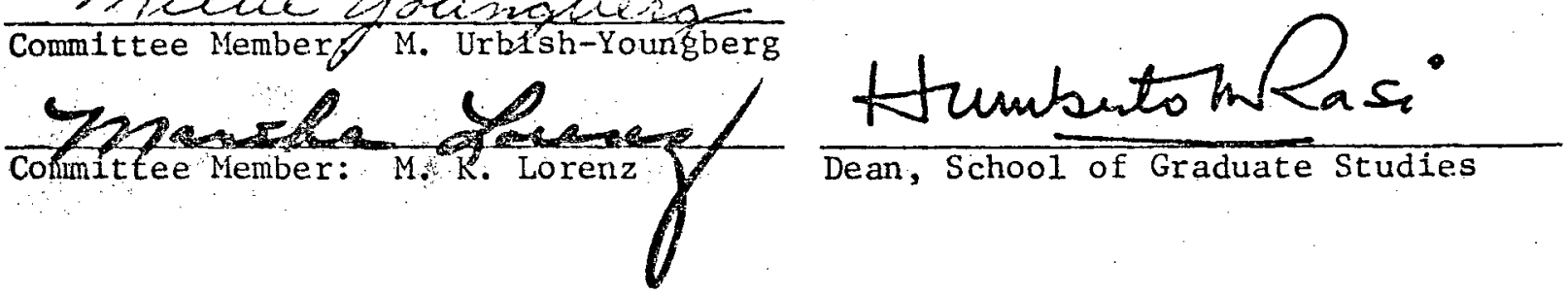
ABSTRACT

SELF-CONCEPT PATTERNS OF INADEQUATE AND ADEQUATE ADULT READERS

by

Anna Klimes

Chairperson: Ruth R. Murdoch 


\section{ABSTRACT OF GRADUATE STUDENT RESEARCH \\ Dissertation}

Andrews University

Department of Education

\section{Title: SELF-CONCEPT PATTERNS OF INADEQUATE}

\section{AND ADEQUATE ADULT READERS}

Name of Researcher: Anna Klimes

Name and title of faculty adviser: Ruth R. Murdoch, Ed.D.

Date completed: July 1977

\section{Problem}

Many of the difficulties which people experience are to a large extent the consequences of faulty perception of themselves. Academic success or failure appears to be deeply rooted in the person's self-concept. The purpose of the study was to analyze the components of self-concept of inadequate and adequate adult readers to determine what patterns of self-concept emerge in various groups. Inadequate and adequate readers were grouped according to sex, race, age, and type of educational institution. 
Method

The Tennessee Self Concept Scale was selected for the study. Measuring positive self-concept, it is composed of five self-concept components--physical, moral-ethical, personal, family, and social-and three self-concept dimensions--identity, self-satisfaction, and behavior. In addition the Michigan State General Self-Concept of Ability Scale was employed to neasure academic self-concept.

Nine hypotheses were developed for the study. The first two compared the means of the total sample and ten subgroups to the normal population. This was tested by a z-test to compare a single sample mean to a hypothesized population mean with known variance. Four hypotheses dealt with comparing the centroids of self-concept dimensions and components of inadequate and adequate readers to the centroid of a normal population. These were tested by a one-sample $\mathrm{T}^{2}$ test. Three hypotheses were tested by discriminant analysis to determine which dimensions, components, and subcomponents exerted the greatest relative weights in separating the inadequate from the adequate readers.

The 569 subjects for the study were drawn from the universities, community colleges, and continuing-education institutions of southwestern Michigan during the school year 1976-1977.

\section{Results}

The self-concept mean of inadequate readers on the whole sample was significantly lower than that of the normal population. The self-concept mean of adequate reaclers on the whole sample was also significantly lower than the population mean. Nine out of ten 
of the subgroups of inadequate readers had mean self-concepts which were significantly lower than that of the normal population. Only the mean self-concept of inadequate black readers was similar to a normal population. of the adequate-reader subgroups, six out of ten were significantly lower than the normal population.

The centroids of the dimensions of self-concept and the centroids of the components of self-concept were significantly lower than the population norm for both the inadequate and the adequate groups.

In determining the relative weights of the dimensions, the components, and the subcomponents of self-concept to best separate. inadequate and adequate readers, it was found that the academic selfconcept has the greatest weight for readers that were male and female and those who attended universities and community colleges.

\section{Conclusions}

On the basis of the findings the following conclusions emerged:

1. Inadequate and adequate adult readers in this study have a lower self-concept than the normal population.

2. A11 categories of inadequate readers except black inadequate readers show significantly lower self-concepts than the normal population.

3. The centroid of the self-concept dimensions and selfconcept components of. inadequate and adequate readers were significantly different from the centroid of the normal population of the Tennessee Self Concept Scale.

4. On a linear combination of the components and subcomponents of self-concept, the positive academic self-concept exerts 
the greatest weight that significantly separates inadequate and adequate adult readers.

5. Fewer variables separate inadequate and adequate university-reading students than community college and continuingeducation students.

6. The physical component and subcomponents of self-concept tended to characterize the inadequate readers at universities and continuing-education institutions while the academic self-concept characterized the adequate readers.

7. The moral-ethical self-concept somewhat characterized all adequate male and female readers but strongly characterized the adequate readers from the continuing-education institutions. 
TABLE OF CONTENTS

LIST OF TABLES . . . . . . . . . . . . . . . xII

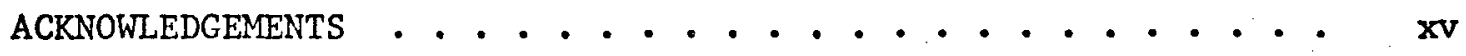

Chapter

I. INTRODUCTION . . . . . . . . . . . . . . . 1

Statement of the Problem . . . . . . . . . . 2

Purpose of the Study ................ 3

Significance of the Study . . . . . . . . . . . . 3

Definition of Terms................. . . . 4

Delimitations ................ . . . . 7

Assumptions . . . . . . . . . . . . . . . . . 7

Organization of the Study . . . . . . . . . 8

II. REVIEW OF LITERATURE . . . . . . . . . . . . 9 9

Historical Perspectives ............. 10

Self-Concept and Academic Performance ....... 13

The Self-Concept of Adults . . . . . . . . . 15

Reading and the Adult Self-Concept . . . . . . . 18

Self-Concept Scales .............. 21

III. RESEARCH DESIGN . . . . . . . . . . . . 26

Null Hypothesis ................ 26

Population for the Study . . . . . ...... 27

Instrumentation .............. . . . 30

Summary of various instruments . . . . . . . . 30

The Nelson-Denny Reading Test . . . . . . 30

The Reading Progress Scale . . . . . . . . . . 31

The American College Testing Program . . . . . . 32

The Tennessee Self Concept Scale (TSCS) . . . . . 33

The Michigan State General Self-Concept of Ability

Scale (SCA) ............. 36

Collection of Data .............. 37

Limitations of the Study ............. 38

Data Analysis ................ 38

vili/ix 
IV. PRESENTATION AND ANALYSIS OF DATA . . . . . . . 40

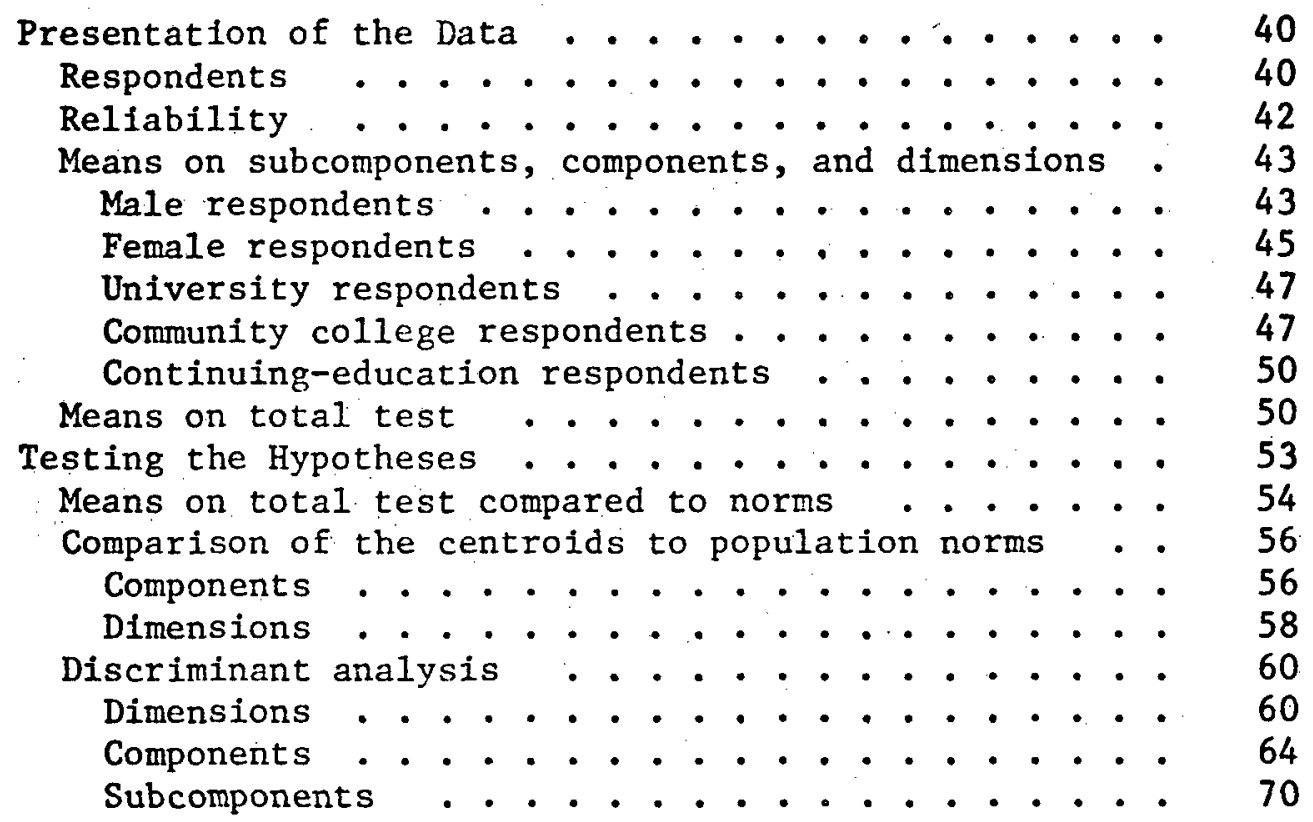

V. SUMMARY, CONCLUSIONS, AND RECOMMENDATIONS . . . . . 78

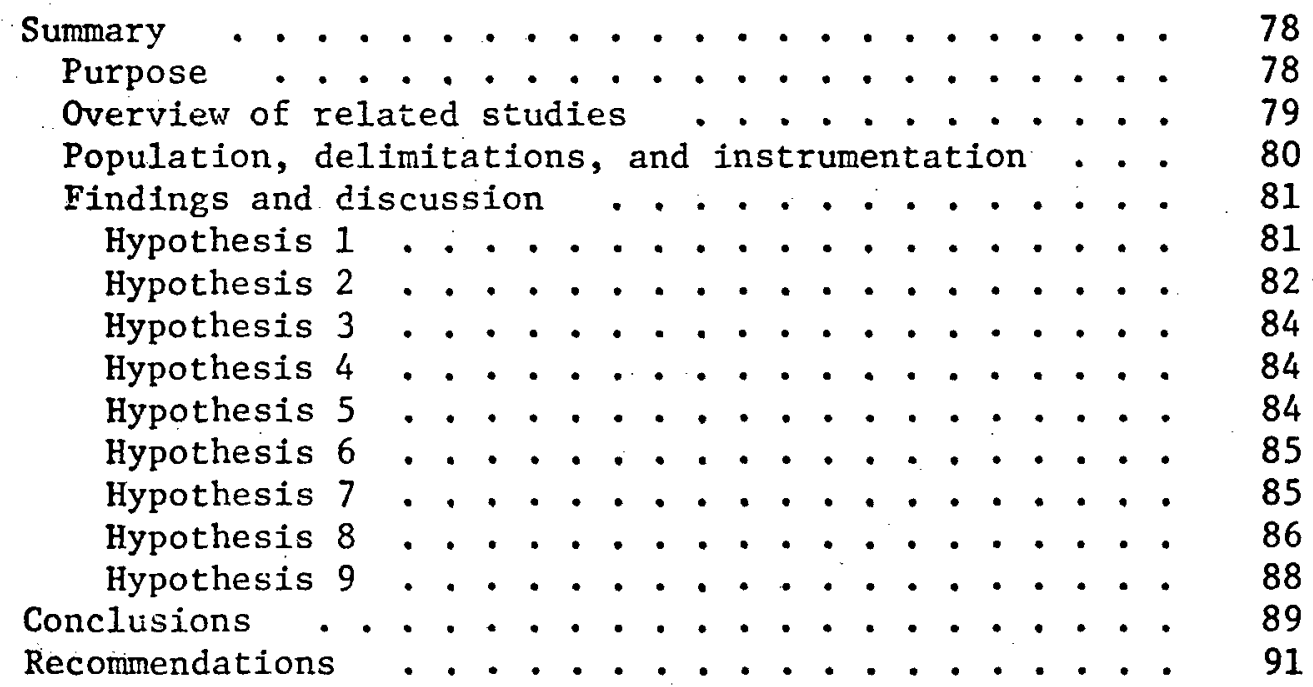

APPENDIX A. Covering Letter . . . . . . . . . . . . 93

APPENDIX B. Instruments . . . . . . . . . . . 95

APPENDIX C. Copyright Permission Letters . . . . . . . . 101

APPENDIX D. Instruction Sheets for Administrators of
Instruments . . . . . . . . . . . 104

APPENDIX E. Discriminant Analysis Tables . . . . . . . 108 
APPENDIX F. Discriminant Analysis Figures . . . . . . . 113

BIBLIOGRAPHY . . . . . . . . . . . . . . 118

VITA ....................... 128 


\section{LIST OF TABLES}

1. The Enrollments of the Reading Improvement Classes and the Total Enrollment of the Educational Institutions Participating in the Study, during the Year 1976-1977

2. Components and Dimensions of the Tennessee Self Concept Scale

3. Number and Percentage of Subjects Participating According to Educational Institutions

4. Reliability Coefficients for the Subcomponents of Self-Concept . . . . . . . . . . . . .

5. Means of Components, Dimensions, and Subcomponents of Self-Concept for Inadequate and Adequate Male Readers .

6. Means of Components, Dimensions, and Subcomponents of Self-Concept for Inadequate and Adequate Female Readers

7. Means of Components, Dimensions, and Subcomponents of Self-Concept for Inadequate and Adequate Readers at the Universities ....................

8. Means of Components, Dimensions, and Subcomponents of Self-Concept for Inadequate and Adequate Readers at the Community Colleges . . . . . . . . . . . .

9. Means of Components, Dimensions, and Subcomponents of Self-Concept for Inadequate and Adequate Readers at the Continuing-Education Institutions

10. Means of Self-Concept of Inadequate and Adequate Reader Groups ......................

11. Comparison of Total Test Means against Population Norm .

12. Comparison on the Centroids of Components of Self Concept . . . . . . . . . . . . . . .

13. Compartson on the Centroids of Dimensions of SelfConcept . . . . . . . . . . . . . . . 
14. Discriminant Function Analysis of the Dimensions of SelfConcept for Inadequate and Adequate Male Readers . .

15. Discriminant Function Analysts of the Dimensions of SelfConcept for Inadequate and Adequate Female Readers . .

16. Discriminant Function Analysis of the Dimensions of SelfConcept for Inadequate and Adequate Readers at the Universities ...................

17. Discriminant Function Analysis of the Dimensions of SelfConcept for Inadequate and Adequate Readers at Community Colleges .................

18. Discriminant Function Analysis of the Dimensions of SelfConcept for Inadequate and Adequate Readers at Continuing-Education Institutions . . . . . . .

19. Discriminant Function Analysis of the Components of SelfConcept of Inadequate and Adequate Male Readers . . .

20. Discriminant Function Analysis of the Components of SelfConcept of Inadequate and Adequate Female Readers . .

21. Discriminant Function Analysis of the Components of SelfConcept of Inadequate and Adequate Readers at the Universities . . . . . . . . . . . . . . .

22. Discriminant Function Analysis of the Components of SelfConcept of Inadequate and Adequate Readers at Community Colleges . . . . . . . . . . . . .

23. Discriminant Function Analysis of the Components of SelfConcept of Inadequate and Adequate Readers at the Continuing-Education Institutions . . . . . . . .

24. Discriminant Function Analysis of the Subcomponents of Self-Concept for Inadequate and Adequate Male Readers.

25. Discriminant Function Analysis of the Subcomponents of Self-Concept for Inadequate and Adequate Female Readers

26. Discriminant Function Analysis of the Subcomponents of Self-Concept for Inadequate and Adequate Readers at the Universities

27. Discriminant Function Analysis of the Subcomponents of Self-Concept for Inadequate and Adequate Readers at Community Colleges 
28. Discriminant Function Analysis of the Subcomponents of Self-Concept for Inadequate and Adequate Readers at Continuing-Education Institutions

29. Weight, Direction, Rank, and Significance of the Dimensions of Self-Concept in Separating Inadequate and Adequate Readers . . . . . . . . . . . . . .

30. Weight, Direction, Rank, and Significance of the Components of Self-Concept in Separating Inadequate and Adequate Readers . . . . . . . . . . . . . .

31. Weight, Direction, Rank, and Significance of the Subcomponents of Self-Concept in Separating Inadequate and Adequate Readers 


\section{ACKNOWLEDGEMENTS}

From its inception to the completion of this dissertation my motto has been "Hither by Thy help I've come" (2 Sam. 7:12). I am humbly grateful to the Lord for the inspiration of thought, for direction in writing, and good health for the task.

Many people have worked to make this venture a reality. I am especially indebted to my doctoral program committee: to $\mathrm{Dr}$. Ruth R. Murdoch, the chairman, for her inspirational example and careful guidance and support throughout the various stages of this study; to Dr. W. Peter Blitchington for the technical research assistance and penetrating questions; to Dr. Wilfred G. A. Futcher for developing the computer programs and for his time and expert assistance in statistical procedures; to Dr. Marion J. Merchant for her scholarly and perceptive criticism on subject matter; and to Dr. Millie Urbish-Youngberg for her unstinting support and understanding when the pressures mounted.

I have appreciated much the psychological support of friends, colleagues, faculty, and students and the material assistance of typists, administrators of tests, and respondents to the questionnaires. Sincere thanks also go to Ruth Ann Plue, Devin Zimmerman and others at the Andrews University Computing Center, to Joyce Jones, the editor, and to Betty Forbes and Corinne Zehm, the final typists.

Finally, I am indebted to my husband, Rudy, for his continuous encouragement and to my children, Anita Heidi, Bonnie, and Randy for their understanding and their $k$ ind assistance in the extra home duties. 
For all who have contributed in bringing this dissertation to its fruttion, I want to express my sincere appreciation.

A. $\mathrm{K}$. 


\section{CHAPTER I}

\section{INTRODUCTION}

Half of the world population cannot read (UNESCO pamphlet, 1958). In the United States one adult out of seven is considered a functional illiterate and one out of every four students throughout the nation manifests "significant reading deficiencies" (Right to Read, 1975). In the modern world those who possess limited skills in reading frequently feel a definite handicap and so suffer isolation from the larger environment. In the academic environment, learning to read and proficiency in other language correlates are considered vital and fundamental.

There are many factors which may exert an enhancing or detrimental influence on the ability of a child to learn to read (Bledsoe \& Garrison, 1962; Brookover, Paterson \& Thomas, 1964; Volhotti, 1973, pp. 33-35). One such factor is his self-concept. On the other hand an individual's ability or inability to read may enhance or lower his self-concept, thus indicating interrelationships between the selfconcept and reading ability (Bond \& Tinkler, 1957; Quandt, 1972).

A child's self-concept is formed on the basis of how others respond to him, what he thinks of himself, and what he would ideally like to be (Gordon, 1968; Quandt, 1972, p. 5). In general, there seems to be a strong tendency for children and adults to act according to the 
dictates of their self-image. If a child repeatedly falls in school, Is rejected by his peers, and belittled by his parents for his failure, he w1ll subsequently develop a consistently poor and negative self-image. If on the other hand he meets with consistent success, his self-image wi11 be enhanced.

\section{Statement of the Problem}

Many of the difficulties which people experience are to a large extent the consequences of faulty perceptions of themselves in relation to the world in which they live. This is especially true in academic pursuits such as reading. Numerous studies using a variety of procedures and instruments have investigated the self-concept and its relationship to academic success (Purkey, 1970; Lewis, 1972; Musik, 1974; Crafts, 1975). These studies have been concerned primarily with the elementary-school students. However, results of recent studies indicate that self-concept of academic ability is associated with academic success at each grade level (Brookover et al, 1965; Wylie, 1974). Psychologists are interested in the self-concept as it pertains to occupations, academics, mental health, and even sports.

A few studies in education cover certain aspects or dimensions of the self-concept in adults as college students (Wyile, 1961, p. 169), but most are concerned with self-concept as a whole. There is little doubt concerning the importance of the self-concept as a determiner of behavior (Purkey, 1970, p. 27).

However, there exists a need to explore further the various dimensions of the self-concept in an effort to determine which of these components characterize the various adult groups. Wylie (1961, pp. 232-33) and McCandless (1967, p. 225) in their critical survey of 
pertinent literature argue that since self-concept is highly complex, careful collection of data on the molecular level will be extremely helpful as a basis for drawing conclusions about global self-constructs (Wylie, 1961, pp. 232-34).

\section{Purpose of the Study}

The purpose of the investigation is to analyze the components of the self-concept of inadequate adult readers.

The corollary purposes of the study are:

1. To compare the self-concept of adequate and inadequate adult readers to the self-concept of the general population

2. To determine the relative weight of the various selfconcept dimensions, components, and subcomponents distinguishing inadequate adult readers from adequate adult readers according to sex and type of education institution.

\section{Significance of the Study}

Educators and sociologists continue to seek solutions to the problem of low reading competency. In 1969 , a bulletin from the United States Office of Education stated that

thirteen percent of the adults in our nation could not read well enough to function independently in our society. These people could not fill out job applications, read highway signs and shop efficiently. It was also noted that one of every four students nationwide demonstrated significant reading deficiencies (Right to Read, 1975).

With the current emphasis that society places upon reading abllity, children and adults who are unable to read well feel socially unacceptable. Whatever the specific or direct causes of their inability to learn to read may have been, the self-concept suffers because of 
their low achlevement in reading. After studying the existing 1iterature dealing with self-concept and school achievement, Purkey (1970) 6tates: "Academic success or fallure appears to be as deeply rooted in concepts of the self as it is in measured mental ability, if not deeper" (p. 14). The study will shed light on the adult learner and his scholastic achievement by focusing on the in-depth patterns of his selfconcept.

\section{Definition of Terms}

Several terms used throughout this research have special meaning for the purpose of this study only and therefore require definition. The terms include:

Self-concept. Self-concept comprises the individual's perception of himself, his perception of what others think of him, and what he ideally would like to be.

Global self-concept. Global self-concept is the total selfconcept which is composed of all the parts or components. Six components of self-concept will be studied: the academic self, physical self, the moral-ethical self, the personal self, the family self, and the social self.

1. Academic self-concept. The academic component of selfconcept refers to an individual's ability to achieve in academic tasks as compared with others involved in the same tasks. It will be measured by the Michigan State General Self-Concept of Ability Scale (SCA).

The following terms which define five self-concept components and three self-concept dimensions are based on the Tennessee SelfConcept Scale (TSCS) Manual (Fitts, 1965, pp. 4-5). 
2. Physical self-concept. The physical component of selfconcept includes the Individual's view of his physical appearance, his health, and his physical skills.

3. Moral-ethical self-concept. The moral-ethical component of self-concept includes moral worth, relationships to God, feelings of being a "good" or "bad" person, and the level of satisfaction with one's religion.

4. Personal self-concept. The personal component of the self-concept reflects the personal worth of the individual, his feelings of adequacy, and his evaluation of his personality apart from his physical and social self.

5. Family self-concept. The family component of the selfconcept reflects one's feelings and perceptions of his worth and value as a family member. It also refers to his status in a close and immedlate circle of associates.

6. Social self-concept. The social component of the selfconcept reflects a person's sense of adequacy and worth in his interaction with people in general. In the social milieu he perceives himself as others see him.

Dimensions of self-concept. Three dimensions of self-concept will be explored: identity, self-satisfaction, and behavior.

1. Identity. The identity dimension of self-concept is an individual's response to the "what I am" items. Here the individual is describing his basic identity as he sees himself, considering his physical self, moral-ethical self, personal self, family self, and social self. 
2. Self-satisfaction. The self-satisfaction dimension of self-concept best reflects the level of self-satisfaction and selfacceptance of an individual considering his physical self, moral-ethical self, personal self, family self, and social self.

3. Behavior. The behavior dimension of self-concept comprises an individual's perception of the way he acts or the way he functions, considering his physical self, moral-ethical self, personal self, family self, and social self.

Adults. Subjects who are above eighteen years of age and are enrolled in the designated educational institutions are considered adults.

Inadequate readers. Adult reading students who rank below the first quartile on the total score for vocabulary and comprehension on the Nelson-Denny Reading Test, or those who scored below the tenth grade on the Revrac test, or those who were unable to read the test, are classified as inadequate readers.

Adequate readers. Adult students who rank above the median on the total score for vocabulary and comprehension on the NelsonDenny Reading Test or those scoring above the third quartile on the American College Test Program (ACT) are classified as adequate readers at the universities. Adults students who scored on the college level on the Reading Progress Scale are classified as adequate readers at the community colleges and continuing-education institutions.

Norma1 population. The normal population is described in the Tennessee Self Concept Scale Manual (Fitts, 1965, p. 12). 
Centroid. The term is the multivariate equivalent of the center of gravity which is the geometrical meaning of a mean on a single variable.

\section{Delimitation}

The study is delimited to adult students enrolled in classes in selected universities, community colleges, and continuing-education institutions in southwestern Michigan during the school year 1976-1977. The continuing education subjects consist of adults enrolled in literacy and reading improvement classes. who may have terminated their formal education at the elementary or secondary level. Adults for whom English is a second language are excluded from the study.

\section{Assumptions}

The underlying assumption of the study is that the selfconcept is influenced by growth, maturation, and experience. Adults tend to deliberate upon aspects and dimensions of self, when responding to a self-report, more than do children. It is assumed, however, that the subjects are aware of their self-concept and respond with frankness and honesty.

It is further assumed that the subjects themselves are best able to evaluate their own self-concepts: Although there is considerable freedom for a subject to overestimate or underestimate himself from item to item, "Those traits on which $S$ would have most objective evidence, on a basis permitting him to compare himself uniformly to others, are usually among the most accurate estimated. . ." (Wylie, 1961, p. 314). 


\section{Organization of the Study}

The study is organized as follows: Chapter I includes the statement of the problem, the purpose of the study, definition of terms, delimitations, and assumptions. In chapter II, the literature Is reviewed. Chapter III describes the research design, lists the null hypotheses, and describes the population and instrumentation used for the study. The data are presented and analyzed in chapter IV. Chapter V summarizes the study and presents findings and conclusions. 
CHAPTER II

\section{REVIEW OF LITERATURE}

The wide range and voluminous body of literature on the selfconcept compels a selective approach to the review of literature for the present study. A brief review of general self-concept literature Is presented first, then research on self-concept as it pertains to reading achievement in educational institutions is considered.

Self-concept as a construct has been well reviewed by Wylie (1961, 1974), Shaver (1973), Gergen (1971), and Wells and Marwell (1976). The popular way to treat self-concept or self-esteem is to think of a person's attitude toward himself as having three aspects-"the cognitive, the affective and the behavioral" (Secord \& Blackman, 1964, P. 579).

Besides occurring in various settings, self-concept appears under an assortment of terms: self-esteem, self-evaluation, selfappraisal, self-love, self-confidence, self-respect, self-acceptance, self-satisfaction, self-worth, sense of competence, and ego strength.

Research literature on self-concept frequently, in effect, equates self-conception with self-esteem (Taylor, 1955; Webb, 1955; Fitts, 1965; Wells \& Marwel1, 1976). Either implicitly or explicit1y. "Self-acceptance and self-esteem are empirically and conceptually related" (Shaver, 1973, p. 45).

Some theorists differentiate certain terms as having widely 
diverse meanings while other theorists use a combination of terms to explain a common phenomenon. "No theorist has been able to work with this term and/or concept" (Weller \& Marwe1l, 1976, p. 231).

Two chief meanings emerge when speaking of self: "the self as subject or agent, and the self as the individual who is known to himself" (Wylie, 1961, p. 1). The word "self-concept" is of a more recent coinage and is commonly referred to as the second meaning. Self-regard, which includes self-respect and self-concelt, is usually thought of as self-esteem (p. 40). However, Wylie (1961, 1974), McCandless (1967), Wells and Maxwell (1976) and other authors, in their review of literature use the same works and refer to this hypothetical construct as "self-concept" (Wy1ie, 1961, 1974) or as "selfesteem" (Wél1s \& Maxwe11, 1976) interchangeably.

In considering the literature pertinent to this study five areas are reviewed. The first covers the historical background. The second cites reviews of literature on the self-concept and the acquisition of academic skills as a background for the next two areas. The third area deals with the adult and his self-concept, while the fourth reviews the topic of reading and the adult self-concept. The fifth area surveys the literature on published adult self-concept scales. Educational studies beginning with 1960 and extending to the present are reviewed.

\section{Historica1 Perspectives}

Any detailed account of the history of the self in the Western world would certainly trace its origins to the Greek writings. Aristotle in his historical record De anima (On the Soul) made a 
distinction between the physical and the nonphysical aspects of the human being. The central core of the nonphysical being, the soul, which is essential and unique in mental operations, was similar to what later theorists understood by "self." Terms such as "mind," "soul," and "psyche" were used interchangeably.

In the seventeenth century Descartes elaborated on Aristotle's theme adding his precise dictum "I think, therefore I am." This notion of the "I"--thinking, knowing entity--became one of the direct influences of the concept of self in modern psychology. In the eighteenth century, Berkeley, Hobbes, Hume, and the brothers, James and John Stuart Mill were notable philosophers and writers focusing on experiences of the self (Misiak \& Sexton, 1966).

William James (1890) stated that "a man's self is the sum total of all that he CAN call his" (p. 291). The self was subsumed under three categories: the Material Me--one's own body, family, home, physical possessions; the Social Me--one's awareness of his identity in other's eyes; and the Spiritual Me--one's awareness of his thinking and feeling and motivation (ibid., p. 298). Cooley (1902) enlarged upon James' view of the relationship between self and the social environment. The work underlies the developmental theory of self-concept beginning with the early years. Cooley proposed the "looking glass" theory of self, in which one perceives his reflection of how he appears to others. The works of both Mead and Cooley were basic to what has been termed the symbolic interactionist theory (Gergen, 1971, p. 7) of the concept of self. Mead felt that through the use of language interaction with others over the course of experience and maturation, the individual developed his "generalized self." 
Freud's concept of the ego and the self, both conscious and unconscious, contributed to the widespread concern with the self. However, Freud's followers, Adler, Horney, Fromm, and Sullivan, have dealt more directly with self-conception and self-esteem (Wells \& Marwell, 1976, pp. 18-22). For Adler it was "superiority striving"; for Fromm, "self-fulfillment"; for Lecky and Maslow, "selfactualization" (ibid. 1972). Allport (1937, 1961) throughout his life argued for a purposeful, rational self and self-awareness.

In 1948, Rainey stated that psychotherapy is a process of changing the self-concept and consequently introduced measures of selfconcept in counseling. Carl Rogers (1951) built the nondirective system of counseling around the importance of human integration and adjustment.

Combs and Snygg (1959) stated that self is determined by the totality of experience of the individual's instance of awareness which they termed the "phenomenological field."

Recently a large body of literature and methodological techniques have been generated around the self-concept (We11s \& Marwe11, 1976, p. 23; Wylie, 1974). Since 1960 there has been a rebirth of interest in the self-concept in psychology and education as witnessed by the writings of an appreciable number of authors including Combs (1962), Diggory (1966), Coopersmith (1967), Quandt (1972), and Wells and Marwell (1976).

In his chapter "Introduction to Theories of the Self," Purkey (1970) summarizes the more salient characteristics of the concept of self by saying: 
(1) that the self is organized and dynamic; (2) that to the experfencing individual the self is the center of his personal universe; (3) that everything is observed, interpreted, and comprehended from this personal vantage point; and (4) that human motivation is a product of the universal striving to maintain, protect, and enhance the self. (p. 13)

\section{Self-Concept and Academic Performance}

Overal1 research evidence from Wylie (1961, 1974), Purkey (1970), Gergen (1971), and Quandt (1972) clearly indicates a persistent and significant relationship between self-concept and academic achievement. Campbell (1965) and Bledsoe (1967) find that girls, both high and low achievers, report higher self-concepts than boys. Shaw and Alves (1960) and Fink (1962) in their studies on high school boys report that achievers rate themselves far more adequate and feel significantly more positive about themselves than do underachievers.

Self-concept is a type of concomitant learning. Supported by the Cooperative Research Program of the United States Office of Education, Brookover, Paterson and Thomas (1962), Brookover et al (1965), and Brookover, Erickson and Joiner (1967) conducted three projects which represent continuous phases of a six-year study. They chose the "symbolic interactionary theory of behavior" (1967, p. iii) to postulate that academic behavior or school learning is limited by the student's self-concept of his ability in these areas. The major portion of this study is addressed to the development of self-concept of academic ability and its impact on academic performance of students from grades seven through twelve. The volume also contains eleven summarized studies based on projects closely connected with the main study. 
Brookover and his colleagues (1965) and V1lhotti (1973) conclude that self-concept of academic ability is associated with academic achievement at each grade level (p. 201). In addition, Frank (1976) posits that it appears so regardless of the students' culture. Further supporting evidence obtained by Reeder (1955), Bodwin (1957), Borislow (1962) and Shaw (1963) indicates that self-rating of students' self-concept has a significant relationship to achievement in a school setting. Unfortunately there are "usual negative correlates of education based on achievement and evaluative stress" (Ellison, 1976, p. 19).

Significant others impressively influence the success of students. "Parents are perceived by more than 90 percent of the students as academically significant others in all grades, seven through ten" (Brookover et al, 1965, p. 208). Brookover et al (1962) in their studies of over 1,000 students conclude that there is "a significant association between the self-concept that an individual held of himself and the perceptions which he felt four others (father, mother, best friend and teacher) had of him" (p. 208). Staines (1958), Davidson and Lang (1960), and Brookover et al (1962, 1967) report student self-concept enhancement by teachers who create an atmosphere of greater psychological security. Rosenthal and Jacobson (1968) state that the teacher through facial expression, posture, and speech subtly helps or hinders the child in his learning. Teacher-pupil congruence and teacher's perception of the student seem to be of greater importance than the method of instruction (Purkey, 1966).

The role of self-concept in reading is described by Bond and Tinker (1957) and by Holmze (1962) as having a "spiral of cycles" 
effect (Quandt, 1972, p. 10). With good reading ability the selfconcept is enhanced and a high self-concept tends to enhance reading ability. Conversely, low self-concept and low reading ability reinforce each other. While productivity is an important ingredient of self-concept, Busby (1976) holds that the "reverse also appears true, namely, that self-esteem is necessary to produce successful achievement" (p. 66). Rosenberg (1965) concludes that competence and confidence are closely inter-related, each fostering the other.

In summarizing his interpretive paper on reading and the selfconcept, Quandt (1972) elaborates on several ideas in fostering positive self-concepts, such as observing the behavior of students, developing a positive classroom and home atmosphere, making the child feel that he is accepted, and providing the child with feelings of success (pp. 11-30). Keys to building self-concept in the classroom, according to Felker (1974), are evaluating one's self-realistically, praising oneself and others, and setting reasonable goals (p. 65).

\section{The Self-Concept of Adults}

All individuals except very little children form some concept of themselves as people. Each has a concept of himself as a unique person, or self, different from every other self. The images a child forms of himself originate in the family circle (Bledsoe \& Garrison, 1962, p. 13). The influence, particularly through the ways in which parents and significant others relate to the child, reverberates throughout his life span (Gordon, 1958). "Parents have an extremely powerful influence on the self-concept because they are both 
conditioners and controllers of information reaching the child" (E11ison, 1976, p. 10).

Individuals are usually unwilling to accept evidence that is contrary to the ways they perceive themselves, striving to protect the self-picture. According to Engel (1959), who studied consistency in adolescent self-concept, self resists modification to a surprising degree. "There are times when self-image appears to shift abruptly-as on a child's first day of school, graduation, marriage and retirement" (Purkey, 1970, p. 11), but Lecky (1945) and Brownfain (1952) hold that preserving one's self intact is the first motive in all behavior. However, change can occur even though there is a direction toward consistency (Moberg, 1976, p. 90). Expected change of selfconcept is basic to counseling, psychotherapy, and remedial teaching (McCandless, 1967).

Block and Thomas (1955) conclude that groups of students who are dissatisfied with themselves or show a large discrepancy between their perceived self and ideal self were judged to be confused, overly introspective, despairing (ibid, 1955), or highly achievement motivated (Martire, 1956). Psychoanalysts contend that psychological adjustment exists when all aspects of the self can be accepted into the conscious self. Maximum adjustment exists when all of an individual's opinions of himself--realistically, objectively, and subjectively--"are entirely acceptable to him" (Bledsoe \& Garrison, 1962, p. 25).

Rogers' (1951) theory of client-centered counseling and Ellison's (1976) approach of Christ-centered living make use of the assumption that self-accepting indivtduals are also accepting of others. 
Block and Thomas (1955) state that a certain amount of resillency is necessary in order to cope with stresses. If a person's perception of himself is close to his idealized self he may tend to "suppress threatening features of himself" (Bledsoe \& Garrison, 1962, p. 27) In not setting high goals. Therefore the maladjusted person may appear well-adjusted employing this defense mechanism (1bid., p. 27).

Subjects who evaluate themselves unfavorably tend to feel anxious, irritable, unhappy, and inadequate. Subjects in the low self-ideal congruence group are characterized by a lack of persistence in work habits and feelings of oppression. They are more likely to feel rejected by both family and friends and tend to react to this by withdrawing within themselves. . . Subjects of the low self ideal congruence group show much more uneasiness in social situations. They tend to stay in the background and to avoid contacts calling for poise and diplomacy, for they are easily hurt and are aware of their proneness to quarrel. (Ibid., p. 26)

The role of the self is recognized in many walks of life, the normal and the abnormal. Culturally certain strata of the milieu generally display negative self-concepts: unhappily married couples (Luckey, 1960), the vocationally immature or jobless (Morrison, 1962; Pound, 1975), unwed mothers (Kogan, Boe, \& Valentine, 1965), delinquents (Schwartz \& Tangri, 1965), welfare recipients (Carson, 1967), the black (Long \& Henderson, 1966; Simpson, 1975), the disadvantaged (Morse \& Piers, n. d.; Rosenthal \& Jacobson, 1968), Mexican-American students (Carson, 1968), and alcoholics (Williams, 1975; Nocks, 1969).

Self-concept is dependent upon a value system or the reaching of goals (Wise, 1976). In the American society, there are many value options open to individuals. One such possibility is the Christian 11fe.

Espousing a Biblical approach of self-concept or self-esteem, one must cut across such 1ssues as the origin of man, the nature of 
man, sin, man's destiny, and a supernatural God (Narramore, 1976; Eìlison, 1976).

The creation account affirms God's positive regard for man. Ellison (1976) asserts that after the fall of man even a more convincing foundation of human worth was found in the act of redemption. "The underlying dynamic of man's self-esteem, or human worth, is the unconditional love of God, expressed in His redemptive act. . . . God values us, so we value ourselves" (p. 3).

Hoekema (1976) and Wise (1976) indicate that' encounter with God as a result of conversion has a profound impact upon the selfconcept of a Christian. Quoting the apostle Paul, Hoekema states that the Christian need not negate his accomplishments (as an indication of a form of humility), but he can with confidence respect himself, accept himself, and express his self-worth, "But by the grace of God I am what I am" (1 Cor 15:10) (Hoekema, 1976, p. 27; E11ison, 1976, p. 7).

The underlying fundamental change in measuring self-concept is no longer two-dimensional (self and others) but three-dimensional (God, others, and self) (Wise, 1976, p. 44).

The directional dynamic shifts the primary basis of positive esteem from the stresses and uncertainties of seeking approval from others to that of pleasing God and receiving His perfect evaluation of well-done as well as his [sic] non-contingent reinforcement of Grace (Ellison, 1976, p. 18).

\section{Reading and the Adult Self-Concept}

Abundant Ifterature has pointed up the importance of the relationship of self-concept and academic achievement including the relationship of self-concept and reading ability. The majority of the 
research studies have been conducted on the elementary school level. The intention here is to cite reading research on the adult level as It relates to the adult self-concept. As more reading-skill courses are being offered for credit at the college level, more research will be attempted in adult reading.

Investigating the role of self-concept in achievement, Roth (1959) administered the Diagnostic Reading Test and the Sentence Completion technique to his college reading-improvement class. of the three categories--the improvers, the nonimprovers, and the attrition group--the improvers were least defensive and most concerned with reading improvement. He concludes that "in terms of their conception of self, individuals have a definite investment to perform as they, do. With all things being equal, those who do not achieve choose not to do so, while those who do achieve, choose to do so" (p. 281).

In a similar investigation Clark (1960) found a positive relationship between a student's academic performance and his perception of the academic expectancies held for him by significant others.

Fennimore (1966) at the Washington State University Clinic investigated the differences in reading achievement and self-concept of 107 students enrolled in the Reading Clinic during the fall semester in 1965. She administered the Nelson-Denny Reading Test and the Self-Concept Scale by Urda1l, Metcalfe, and Grade. Results indicate that "students in the study changed significantly at the .01 level in all variables except self-appraisal" (Fennimore, 1966, p. 56). There seems to be less disparity between the self-image and the idealized self of groups whose self-concept was low than of groups whose selfconcept rated high. 
At the University of Western Australia, Anderson (1961) tested 290 males and 125 females who enrolled for professional courses. They were administered the Cooperative Reading Test (Higher Level Form Y) and the Cattel 16 Personality Factor Questionnaire. The general personality description of the good reader, according to test results, appears to include introversion, emotional sensitivity, self-sufficiency, and, to a lesser extent, radicalism and low super-ego strength. In a Marquette University, Milwaukee, study, 321 college freshmen were given the Reading Versatality Test and the Adjective Check List. Brunken (1966) found that efficient and effective readers possessed a high degree of personality traits conducive to good adjustment to college and the working world, while low-rate ineffective readers possessed more undesirable characteristics for success in academic achievements and in the world of work.

Ford's study (1972) was an investigation into the factors involved in reading ability of sixty first-year college students. The factors analyzed were socioeconomic background, mode of linguistic expression, attitude toward reading, interest in reading, level of aspiration, community environment, age, sex, and intelligence. The findings show an association between certain components of the home environment with reading strength and linguistic expression.

Crafts (1975) found that when community college students received group counseling in conjunction with reading techniques, there were positive changes in both reading improvement and selfconcept. The Nelson-Denny Reading Tests and the Tennessee Self Concept Scale were administered. Most scores on the Tennessee Self Concept Scale showed improvement, though this improvement was not 
statistically significant at the .05 level. However, the noncounseling group had none. Defrain (1970) also found the greatest attrit1on rate among his 197 freshmen who reported a poor self-concept on the Englander Scale and received low scores on the Nelson-Denny Reading Test.

\section{$\underline{\text { Self-Concept Scales }}$}

Theoretically, self-concept is directly measured by asking Individuals about themselves and rating them on various scales. Snygg and Combs (1949) suggest that individuals who are asked about the diferent aspects of themselves (e.g. at work, at school) will reveal other dimensions of self-concept. Different people may derive selfesteem from widely differing sources that as yet are not being tapped (Robinson \& Shaver 1973, p. 47).

The first comprehensive evaluation of the diverse instruments and the methodologies of various studies was made by Wylie in 1961 . She concluded that "the total accumulation of substantive findings is disappointing, especially in proportion to the great amount of effort which obviously has been expended" (p. 317). She stated that the collection of data on the components of self-concept would be extremely helpful in order to base conclusions on the global self-constructs. An indication of the powerful surge of interest in the self-concept is made apparent by the rapid increase of self-concept instruments. Robinson and Shaver have extended their appraisals of self-concept instruments from nineteen in 1969 to thirty-three in 1973 and a bibliography of thirty other scales.

Among the scales specifically designed to measure self-esteem 
or self-concept of adults, the following eight scales, according to

Robinson and Shaver (1973), represent the best instruments in the

field (p. 56):

The Tennessee Self Concept Scale (Fitts, 1965)

The Piers-Harris Children's Self-Concept Scale (Piers, 1969)

Janis-Field Feelings of Inadequacy Scale (Eagly, 1967)

Self-Esteem Scale (Rosenberg, 1965)

Se1f-Esteem Inventory (Coopersmith, 1967)

Index of Adjustment (Bills et a1, 1951)

Butler-Haigh Q-Sort (Butler \& Haigh, 1954)

Miskimins Self-Goal-Other Discrepancy Scale (Miskimins \& Braucht, 1971). (Ibid., p. iii)

The Tennessee Self Concept Scale is rated highest as a measure of adult self-concept concerning its validity and reliability (pp. 232-33), the independence of the five named components (Fitts, Adams, Radford, Richard, Thomas B., Thomas M. \& Warren, 1971, pp. 48-9), and its relevancy to normal and abnormal subjects (Fitts, 1965).

In the field of adult personality testing, the adjective scales have been widely utilized. Allport's (Allport \& Odbert, 1936) list of 17,953 traits of personality has given rise to various attitude and psychological scales like the Cattell's 16 PF and the Adjective Check List (Cough \& Heilbrun, 1965). The latter consists of three hundred adjectives. Subjects check the adjectives which are self-descriptive. The number of adjectives indicative of low selfconfidence are subtracted from those indicative of high self-confidence. Utilizing forty-eight adjectives, MARS (Quereski, 1970) covers four categories: unhappiness, extroversion, self-assertiveness, and productive persistence; while Leary's (1957) check list describes the two main polar dimensions such as dominance-submission or love-hate.

B111s Index of Adjustment and Values (Bills: Vance \& McLean, 1951) measures forty-eight traits. A derivative of Allport's work, 
It has given impetus to the creation of several other scales. Bledsoe (1964) selected thirty adjectives, and Gergen and Morse (1967) selected thirty-seven for their measure of self-consistency and integration of self-concept.

The forerunner of the Q-Sort scales was the Butler-Haigh Q-Sort (1954). With the emergence of the Rogers' client-centered play and therapy, this method came into wide use (Bennett, 1964). It is used to measure descrepancies between the self-concept and the ideal selfconcept. The client chooses a list of statements (or adjectives) which are appropriate for his self-concept. He then segregates these as to order of importance of his view of himself (real self). A similar list is made for how he would like to perceive himself (idealized self). In the Butler-Haigh Q-Sort, one hundred items on cards are distributed in nine piles which constitute various aspects of selfconcept such as self-acceptance, sexual esteem, and poise (Block, 1961).

Measuring components of self-concept with sentence (Simmons \& Lamberth, 1961) and adjective items (Corsini, 1956), it is possible to measure family structure and other social relations.

The Self-Esteem Scale (Rosenberg, 1965) and the Self-Esteem Inventory (Coopersmith, 1967) were developed for use with young age groups. They have been widely used for adult studies.

The Coopersmith Inventory (1967) utilizes the forced choice of a negative or a positive response to twenty-five items described as tapping appraisals of peers, parents, school, and personal interest. The Thomas-Zander Ego Strength Scales (Zander \& Thomas, 1960) measure ego strength as it relates to group pressure on a true-false cholce. 
Open-ended questionnaires, such as Duncan's Personality Integration Scale (1966) and Kuhn and McPartland's (1954), presumably tap phenomenological reserves. The latter test is sometimes called the W-A-Y (Who Are You) technique.

A widely-used style for self-concept scales is the Likerttype positive-negative scale. The Berger (1952) and Phillips (1951) self-acceptance scales are two older scales designed to test the relationship between self-acceptance and acceptance of others. The Revised Janis-Field Scale (Hovland \& Janis, 1959) was originally designed to measure feelings of inadequacy in persuasibility, and the four-point Self-Esteem Scale (Rosenberg, 1965) was origina11y deve1oped to measure self-acceptance in high school students. To avoid problems with self-report, McDaniel (1969) rated self-concept on thirty items by observers such as teachers.

The responses of the Brown (1961) Self-Report Inventory intend to reflect the subject's self-esteem and general adjustment on a fortyeight-item scale. Two Likert-type instruments used in the clinical and school setting are the Tennessee Self Concept Scale (TSCS) (Fitts, 1965) and the Repression-Sensitization Scale (Byrne, 1963). The latter measures defensive style while the TSCS has been shown to measure levels of personal effectiveness in normals and levels of psychopathy in disturbed individuals. The writer of this paper chose the TSCS because it proposes to measure various components of self-concept, rather than the global self-concept or specific but limited components. Also TSCS includes questions on the moral-ethical component of selfconcept.

The Miskimins Self-Goal-other Discrepancy Scale (Miskimins \& 
Braucht, 1971) rates the general, social, and emotional areas of selfconcept on a nine-point differential scale, Cutick (1962), Diggory (1966), and Shrauger and Rosenberg (1970) designed and modified the Self Description Inventory which appraises twelve goal-oriented activIties on a percentage differential. By far the most widely used are the adjective differential scales (e.g. good-bad; calm-anxious). An Innovative measurement technique, the open-scale items which allow respondents to insert their own dimensions of rating, was introduced by Sherwood (1962).

Kelly (1958) was critical of a nomethetically-conceived standardized test as a counseling tool. He argued that the unconstructed test allows the subject freedom to express his own construction of the world to a greater extent. The standardized approach gives information on how the person measures up to the mold of the test or to the constructor's yardstick (Kelly, 1958, pp. 33-64). However, this is true for any objective instrument which is designed to make a statisical analysis.

Attitude scales are designed to measure complex psychological constructs such as self-concept. This is usually accomplished by some type of questionnaire.

Q-Sort adjective and statement scales are among the most widely used self-concept scales. Employing the Likert-type scale, the subject may evaluate himself and/or be evaluated by observers. Openended questionnaires yield informative data but are difficult to subject to statistical computation. Q-Sort adjective and statement scales, Likert-type scales, differential scales, and open-ended questionnaires are most frequently used. 
CHAPTER III

\section{RESEARCH DESIGN}

This chapter describes the research design used to study the self-concept patterns of inadequate and adequate readers. To make this comparison an ex post facto research methodology is used (Kerlinger, 1973, p. 379). An attempt is made to study in depth the self-concept components and dimensions of inadequate adult readers to see what patterns emerge. Similar analyses are carried out for adequate adult readers. The self-concept components and dimensions of the inadequate and adequate readers are then compared to the norms and to each other.

\section{Nu11 Hypotheses}

The study examines the following null hypotheses:

1. There is no significant difference between the total selfconcept of inadequate adult readers and of the normal population as described in the TSCS norms over the whole sample and as categorized according to sex, race, age, and educational institution.

2. There is no significant difference between the total selfconcept of adequate adult readers and of the normal population as described in the TSCS norms over the whole sample and as categorized according to sex, race, age, and educational institution.

3. There is no significant difference between the centroid of the components for the inadequate readers and the centroid for the norm group. 
4. There is no significant difference between the centroid of the components for the adequate readers and the centroid for the norm group.

5. There is no significant difference between the centroid of the dimensions for the inadequate readers and the centroid for the norm group.

6. There is no significant difference between the centroid of the dimensions for the adequate readers and the centroid for the norm group.

7. There is no linear combination of the three deimensions of self-concept which distinguishes significantly inadequate adult readers from adequate adult readers as categorized by sex and educational institution.

8. There is no linear conbination of the six components of self-concept which distinguishes significantly inadequate adult readers from adequate adult readers as categorized by sex and educational institution.

9. There is no linear combination of the sixteen subcomponents of self-concept to significantly distinguish inadequate adult readers from adequate adult readers as categorized by sex and educational institution.

\section{Population for the Study}

The present study is concerned with two categories of subjects: adult students whose reading achievement is Inadequate and adult students whose reading achievement is adequate. 
The subjects were drawn from the higher education institutions and public school continuing-education institutions of southwestern Michigan during the school year 1976-1977.

Table 1 presents the enrollment of the reading-improvement classes and the total enrollment of the institutions.

To select the inadequate readers, all available adult students enrolled in the reading-improvement classes at the above-named institutions were administered the Nelson-Denny Reading Test. Those scoring below the first quartile on the total score for vocabulary and comprehension were classified as inadequate readers. Students enrolled in literacy classes and high-school-completion classes who were unable

\section{TABLE 1}

THE ENROLLMENTS OF THE READING IMPROVEMENT CLASSES AND THE TOTAL ENROLLMENT OF THE EDUCATIONAL INSTITUTIONS

PARTICIPATING IN THE STUDY, DURING THE YEAR 1976-1977

\begin{tabular}{lcc}
\hline Educational Institution & $\begin{array}{c}\text { Enrollment of } \\
\text { the } \\
\text { Reading Classes }\end{array}$ & $\begin{array}{c}\text { Total Enrollment } \\
\text { of } \\
\text { the Institution }\end{array}$ \\
\hline $\begin{array}{l}\text { Andrews University } \\
\text { (Undergraduate) }\end{array}$ & 104 & 2,063 \\
$\begin{array}{l}\text { Western Michigan University } \\
\text { (Undergraduate) }\end{array}$ & 72 & 32,976 \\
$\begin{array}{l}\text { Lake Michigan College } \\
\text { Southwestern Michigan College } \\
\text { Continuing-Education }\end{array}$ & 145 & 3,321 \\
$\quad$ Total & $\frac{135}{516}$ & 1,305 \\
\hline
\end{tabular}


to read the Nelson-Denny Reading Test were also classified as Inadequate readers.

To obtain a comparable number of adequate readers, three different methods were used.

At Andrews University, subjects were chosen from a computerIzed student list. Every fifth name was selected totaling 325 potential subjects. These students were contacted by letter (appendix A) and self-perceived adequate readers were invited to meet in two groups at different dates. There the Nelson-Denny Reading Test and the self-concept questionnaire were administered. The number of subjects that responded was 143. Of these 103 could be classified as adequate readers, scoring above the median on the total for vocabulary and comprehension on the Nelson-Denny Reading Test.

At Western Michigan University, those students whose American College Testing Program (ACT) scores ranked above the third quartile were chosen as candidates for the questionnaire. Of the eighty subjects who were given the questionnaire twenty-three completed and returned them.

Subsequently the students in two English classes and two psychology classes were administered the Nelson-Denny Reading Test. of these seventeen adequate readers emerged and participated in the study. At the community colleges, whole classes of students in nursing, psychology, and English were administered The Reading Progress Scale (Carver, 1975) and the self-concept questionaire. Of the 212 volunteers, seventy-five subjects were adequate readers and their data were used in the study. 
At the continuing-education institutions, the directors chose better readers from among crafts, business, and socially-oriented enrichment classes. Of the eighty-five volunteers which were given The Reading Progress Scale, seventy-three subjects qualified as adequate readers. These were administered the self-concept questionnaire. A tablulation of the total participant group is present in table 3 .

\section{Instrumentation}

In order to explore the self-concept of adult adequate and inadequate readers, three reading instruments and two self-concept instruments were utilized.

\section{Summary of various instruments}

The Nelson-Denny Reading Test. The Nelson-Denny Reading Test is a high school and college measure of three major elements of reading ability, namely, vocabulary, comprehension, and reading rate. The total score for vocabulary and comprehension was used in the present study. Percentile ranks and grade equivalents can be taken for grades nine through sixteen. Normally the test takes forty minutes to administer.

The comprehension passages were chosen from a wide variety of subject-matter fields so that the test would not favor students with a strong background in any one field. The items for the comprehension test were "constructed to reflect the variety and complexity of reading skills" (Brown, Nelson \& Denny, 1973, p. 23) useful in a collegiate program. 
Evidence of validity is Indicated by the fact that the test has a relatively high correlation coefficient of .67 as a predictor of potential scholastic ability (p. 14).

Four forms of the test are currently used. The Nelson-Denny Reading Test was first designed in 1929 to provide a measure of reading ability in terms of vocabulary and comprehension. In 1960, Brown and the two other authors added a measure of reading rate to the revised tests (p. 26). Forms A and B belong to this revision. The latest revision by Brown, Nelson, and Denny in 1973, which yielded Forms $C$ and D, was used for this study. A sample of over 1,400 was selected to determine reliability by the equivalent forms method.

Forms $C$ and $D$ were administered to the same students in two different sessions. One part of the group took Form C while the other part took Form D. Three weeks later, the first part of the group took Form $D$ while the second part took Form C. (p. 26)

The results of this test-retest with equivalent forms indicated that reliability coefficients on the total score for vocabulary and comprehension were .82 for grade nine, .87 for grade ten, .91 for grade eleven, and .90 for grade twelve. The split-half reliability coefficient for grades nine to sixteen ranged from .90 to .98 for vocabulary and .80 to .84 for comprehension.

The Reading Progress Scale. The Reading Progress Scale is a seven-minute comprehension, speed, and accuracy test. It is a simple, efficient instrument designed to approximate the level of reading ability.

The test consists of four reading passages. As the subject moves through each passage, he pauses to mark one word from two choices that best fits the sentence. Eighteen correct answers out of 
twenty are expected in order to pass each passage. If the subject completes all four passages accurately, his "reading skill mastery is sufficient.. to . . comprehend and retain the information a college student is likely to encounter in his first year classes" (Carver, 1975, p. 2). He thus receives a score of 4 which means that his readability level is common to that of grades 10 to 12 . A score of 3 indicates a readability level of grades 7 to 9 ; a score of 2 of grades 4 to 6 ; and a score of 1 of grades 1 to 3 . The test was evaluated as a valid and reliable instrument of reading ability at the Michigan Reading Association in May 1975, but the data on the norms has not been published as yet.

The time allotment necessary to administer the Nelson-Denny Reading Test and the questionnaire could not be provided for at community colleges and continuing-education classes in order to obtain adequate readers.

Since no other standardized reading test was appropriate for the community colleges and continuing-education institutions, The Reading Progress Scale was used even though the research form and reliability data of the test were not yet available.

The American College Testing Program. The American College Testing Program (ACT) is administered four times a year at designated locations for grade-twelve students, freshmen in college, and juniorcollege students preparing to transfer to a four-year college. It ylelds five scores: English usage; mathematics usage, social studies reading, natural science reading, and composition. "The questions do not call directly for specific information, rather they test the student's ablilty to use whatever knowledge he possesses in the solution 
of complex problems" (Buros, 1965, p. 51). Each of four tests takes about forty minutes to complete.

For each of the four tests, the local high-school norms, the state college-bound norms, and the national college-bound norms are presented. "The standard error of measurement for each of the ACT tests is approximately 2 ; for the composite score it is about $1^{\prime \prime}$ (American College Testing Program, 1976, p. 11). The best known and most widely used of the different ACT student assessments was standardized on approximately one million college-bound students in the 1975-76 school year (p. 3).

The Tennessee Self Concept Scale. The Tennessee Self Concept Scale (TSCS) (Fitts, 1965) is a self-report measure which aims to measure positive self-concept. It is available in two forms, namely, a Counseling Form and a Clinical Research Form. Both forms use exactly the same items but the forms are scored and scaled by different criteria. The Counseling Form which was used in this study yields twenty-four pertinent profile scores.

The TSCS is comprised of one hundred items or statements to which the subject responds on a Likert-type, five-point scale. Ninety items are distributed among five general components: physical self moral-ethical self, personal self, family self, and social self. Each of these five components shown in table 2 is represented by three separate dimensions which may be visualized as a three-by-five grid.

Independent self-concept scores may be obtained from fifteen intersecting categories or subcomponents: physical-identity, physicalself-satisfaction, physical-behavior, moral-ethical-identity, moralethical-self-satisfaction, moral-ethical-behavior, personal-identity, 
TABLE 2

COMPONENTS AND DIMENSIONS OF THE

TENNESSEE SELF CONCEPT SCALE

\begin{tabular}{|c|c|c|c|c|c|}
\hline \multirow[b]{2}{*}{$\begin{array}{c}\text { Dimensions } \\
\text { (3) }\end{array}$} & \multicolumn{3}{|c|}{ Components (5) } & \multirow[b]{2}{*}{$\begin{array}{l}\text { Famfly } \\
\text { Self }\end{array}$} & \multirow[b]{2}{*}{$\begin{array}{l}\text { Social } \\
\text { Self }\end{array}$} \\
\hline & $\begin{array}{l}\text { Physical } \\
\text { Self }\end{array}$ & $\begin{array}{l}\text { Moral-ethical } \\
\text { Self }\end{array}$ & $\begin{array}{l}\text { Personal } \\
\text { Self }\end{array}$ & & \\
\hline Identity & $\begin{array}{l}\text { Phys1cal- } \\
\text { Identity }\end{array}$ & $\begin{array}{l}\text { Moral-ethlcal- } \\
\text { Ident1ty }\end{array}$ & $\begin{array}{l}\text { Personal- } \\
\text { Identity }\end{array}$ & $\begin{array}{l}\text { Family- } \\
\text { identicy }\end{array}$ & $\begin{array}{l}\text { Social } \\
\text { ident1:y }\end{array}$ \\
\hline $\begin{array}{l}\text { Self- } \\
\text { satisfaction }\end{array}$ & $\begin{array}{l}\text { Phys1cal- } \\
\text { self- } \\
\text { satisfaction }\end{array}$ & $\begin{array}{l}\text { Moral-ethical- } \\
\text { self- } \\
\text { satisfaction }\end{array}$ & $\begin{array}{l}\text { Personal- } \\
\text { self- } \\
\text { satisfaction }\end{array}$ & $\begin{array}{l}\text { Family- } \\
\text { self- } \\
\text { satisfaction }\end{array}$ & $\begin{array}{l}\text { Social- } \\
\text { seli- } \\
\text { satisfaction }\end{array}$ \\
\hline Behavior & $\begin{array}{l}\text { Physical- } \\
\text { behavior }\end{array}$ & $\begin{array}{l}\text { Moral-ethical- } \\
\text { behavior }\end{array}$ & $\begin{array}{l}\text { Personal- } \\
\text { behavior }\end{array}$ & $\begin{array}{l}\text { Family- } \\
\text { behavior }\end{array}$ & $\begin{array}{l}\text { Sociai- } \\
\text { behavior }\end{array}$ \\
\hline
\end{tabular}

personal-self-satisfaction, personal-behavior, family-identity, familyself-satisfaction, family-behavior, social-identity, social-selfsatisfaction, and social-behavior.

The total positive self-concept score is derived from ninety items or questions. Because some subjects make a deliberate attempt to present a favorable picture of themselves, a ten-item lie-scale from the Minnesota Multiphasic Personality Inventory (1951) is included in the TSCS. Subjects whose results indicate a high positive score on selfcriticism are disqualified from the study.

Population norms are based on a variety of samples of 626 people, aged twelve to sixty-eight "with approximately equal numbers of both sexes, both Negro and white subjects, representatives of a11 social, economic and intellectual levels and educational levels from 6th grade through the $\mathrm{Ph} . \mathrm{D}$. degree" (ibid p. 4). The mean total selfconcept was 345.57 (p. 14). Test-retest data on sixty college students showed reliability coefficients of .92 for the total positive score 
and between .70 and .90 for various subscores (Robinson \& Shaver, 1973, p. 38; Fitts, 1965, p. 14).

Fitts et al (1971) assert that content validity has been met. The 1tems in the TSCS have been categorized by a panel of judges and only items on which there was unanimous agreement were retained in the scale (pp. 46, 47). Vacchinano and Strauss (1968) report construct validity of the TSCS using factor analysis based on the 100-item scale offering support for the independence of the five named components (Fitts et al, 1971, pp. 48, 49).

Regarding discriminant validity, the items have not been distinguished as to social desirability "(although it is likely that it would be fairly high since the desirability of most of the statements is clear)" (Robinson \& Shaver, 1973, p. 69). Although Fitts (1965) implicitly assumes discriminant validity, Wylie (1974) states that it seems unlikely that discriminant validity between rows and columns can be established (pp. 232-33).

Before choosing the instrument for the present study, thirtytwo college students, comprising adequate and inadequate readers, were administered seven instruments which the writer chose as relevant.

The seven self-concept questionnaires evaluated by the students were the TSCS (Fitts, 1964), the Self-Cathexis Scale (Seacord \& Jourard, 1953), the Self-Concept Semantic Differential (Pervin \& Li11y, 1967), the Self-Concept Semantic Differential (Schwartz \& Tangri, 1965), the Self-Esteem Inventory (Like Me, Unlike Me) (Coopersmith, 1967), the Adjective Q-Sort for Non-Professional Sorters (B1ack, 1961), and the Self-Acceptance Scale (Berger, 1952). The students responded to 
and then evaluated each instrument. A large percentage stated that the location on differential scales with seven points or more were difficult to pinpoint. Several inadequate readers who characteristically perseverate in reading found it disconcerting to respond to adjective scales, as it was difficult to focus on the adjective at hand while still thinking of the previous one. The statements in the TSCS clearly focus attention to the item at hand. (See appendix B, items $16-115$.

Because of its "multi-dimensional descriptions of the seif" (Fleck, 1976, p. 131; Fitts, 1965, p. 1), the TSCS was chosen by the writer as the instrument for the study rather than the global selfconcept or specific but limited components of the self-concept. The writer is especially interested in the moral-ethical self-concept component which most other authors of self-concept instruments ignore. The scale seems to be "simple for the subject, widely applicable, well standardized" (Fitts, 1965, p. 1).

Permission for the use of the TSCS was granted in a letter by Dr. William H. Fitts (appendix C).

The Michigan State General Self-Concept of Ability Scale. The Michigan State General Self-Concept of Ability Scale (Brookover et al, 1967), hereafter referred to as "SCA," constitutes the sixth component of self-concept used in this study. It was chosen to add an important component, academic self-concept, not included in the TSCS.

The SCA was developed under the United States Office of Education Cooperative Research Project No. 845 through Michigan State University's Human Learning Research Institute (Brookover et a1, 1967, p. 59). 
The scale contains eight 1tems. Each item is scored from five to one with the higher self-concept alternatives receiving the higher values. The respondent is asked to compare his competence with that of others in his social system. The reliability coefficients ranging from .77 to .88 of the SCA scale is higher than those typically reported for attitude scales.

The perceived evaluations by parents, friends, and teachers of academic ability of 561 subjects correlated between .775 and .927 by Hoyt's Analysis of Variance.

The fifteen-item pretest was subjected to item analysis and Guttman scaling. "Items with less than .50 point biserial correlation with the total score were eliminated. The resulting items were subjected to Guttman scalogram analysis. . ." (Brookover et al, 1967, p. 158). Items with duplicated responses were also eliminated. "The remaining eight items formed a Guttman Scale with a .91 coefficient of reproducibility" (Torgenson, 1958, p. 159).

Permission for the use of the SCA was granted in a letter by Dr. W. B. Brookover. (See appendix C.)

\section{Collection of Data}

The procedure for selecting inadequate and adequate readers has been explained in the description of the population.

At Andrews University, the writer administered the instrument to participating students. At the other institutions the writer selected one or two professors who coordinated the administration of the instruments.

The data from the questionnaire were recorded by the subjects 
on an OpScan computer form. The questionnaire consisted of three parts: the biographical questionnaire, the SCA questionnaire, and the TSCS questionnaire. Numbers 1 through 7 were used to record biographIcal data; numbers 8 through 15 were used to record SCA data, and numbers 16 through 116 were used to record TSCS data (appendix B). Names of subjects were withheld to ensure more accurate responses.

\section{Limitations of the Study}

The study was subject to a number of limitations. The adequatereader respondents did not represent a random sample but were chosen from the available sample. Consequently, a cautious approach to generalization from the conclusions of the study is expected.

In the course of gathering data, it was found that the instructors would allow only one forty-five-minute class period for the administration of the Nelson-Denny Reading Test and the Self Questionnaire. Since this procedure often takes sixty to sixty-five minutes, it was decided to use the seven-minute Reading Progress Scale. This was another limitation of the study.

It was also not possible to control for intelligence because previous tests were not available.

\section{Data Analysis}

The returned data were computer scored. The items were scored according to the negative or positive direction--positive statements were scored 1, 2, 3, 4, 5 for responses from completely false to completely true, and negative statements were scored $5,4,3,2,1$ from completely false to completely true. About one-half of the statements were positive and one-half were negative. (See appendix B.) 
Sets of 1tem scores were summed to yleld the following totals: the sixteen subcomponents of self-concept (the cells of table 3 plus the SCA score); three dimensions of self-concept (the row totals of table 3); the six components of self-concept (the five-column totals of table 3 plus the score on the SCA); and a total self-concept score (sum of all fifteen cells of table 3). (See appendix C.)

Hypotheses 1 and 2 were tested by a z-test to compare a single sample mean to a population mean with known population variance. The computer program used was TSISAMN, written by Futcher (1975). Hypotheses 3 through 6 were tested by use of the one-sample $T^{2}$ test (Tatsuoka, 1971, pp. 76-78) to compare the centroid of a single sample to a population centroid, with unknown population variance-covariance matrix. The Computer program used was ISAMSIGTST, written by Calkins (1977) .

Hypotheses 7 through 9 were tested by multiple discriminant analysis. The computer program used was MUDISC, a modification by Futcher and the Andrews University Computing Center (1976) of the discriminant analysis program in Overall and Klett (1972, pp. 300-306). These three hypotheses were tested separately for different categories of sex and educational institution.

$$
\text { For all tests, } \alpha \text { was set at .05. }
$$


CHAPTER IV

\section{PRESENTATION AND ANALYSIS OF DATA}

The purpose of this chapter is to present and analyze the data for the study. The chapter is divided into two main sections. In the first section the basic data are presented, with some subjective impressions. In the second section the data are analyzed by testing the hypotheses in major categories.

\section{Presentation of the Data}

The data are presented in three different sections. The first section is introductory, giving the information on the subjects or respondents and the reliability of the instrument. The second section presents five summary tables of means of subcomponents, components, and dimensions. The means for the total test are presented in the final section.

\section{Respondents}

For the present study, the self-concept questionnaire was administered to 848 individuals. Of these 252 placed in neither the inadequate-reading group nor the adequate-reading group and were thus deleted from the study. There were 596 OpScan sheets sent to the computer. Table 3 shows the number and percentages of subjects, according to educational institution, who completed the Self 
TABLE 3

NUMBER AND PERCENTAGE OF SUBJECTS PARTICIPATING

ACCORDING TO EDUCATIONAL INSTITUTION

\begin{tabular}{lcccc}
\hline & \multicolumn{2}{c}{ Inadequate Readers } & Adequate Readers \\
\cline { 2 - 5 } Educational Institution & Number & Percent & Number & Percent \\
& & & 103 & \\
\hline Andrews University & 93 & & 39 & \\
Western Michigan University & 55 & 51.92 & 142 & 48.08 \\
Tota1--Universities & 148 & & 30 & \\
Lake Michigan College & 34 & 51 & 48.80 \\
Southwestern Michigan College & 51 & & 81 & 46.43 \\
Total--Colleges & 85 & 51.20 & 65 & 48.32 \\
Continuing-education & 75 & 53.57 & 288 & \\
Grand Total (596) & 308 & 51.68 & & \\
\hline
\end{tabular}

Questionnaire and were classified as inadequate or adequate readers. of this number, 18 were rejected by the computer because of items that respondents failed to mark or marked twice in the SCA and TSCS scales in place of the one mark required.

A total of 9 subjects failed on the self-criticism scales (appendix B) because they seemed to make a deliberate attempt to show a favorable picture of themselves as indicated by the ten-item liescale (McKinley and Hathaway, 1951). These subjects scored 46 through 50 on the self-criticism scale that was designed for the highest total score of 45 . 
The data of 569 respondents were used in the analysis. The 18 OpScan sheets rejected by the computer because of Incorrect marking and the 9 subjects who failed the self-criticism scale were included in table 3 .

\section{$\underline{\text { Reliability }}$}

In the present study, the scales for each subcomponent of selfconcept were analyzed for reliability. Table 4 presents the reliability coefficients for each subcomponent as estimated by the coefficient

TABLE 4

RELIABILITY COEFFICIENTS FOR THE

SUBCOMPONENTS OF SELF-CONCEPT

\begin{tabular}{ll}
\hline \multicolumn{1}{c}{$\begin{array}{c}\text { Self-Concept } \\
\text { Subcomponent }\end{array}$} & $\begin{array}{c}\text { Reliability } \\
\text { Coefficient (alpha) }\end{array}$ \\
\hline Physical-identity & \\
Moral-ethical-identity & .6277 \\
Personal-identity & .6439 \\
Family-identity & .5837 \\
Social-identity & .7100 \\
Physical-self-satisfaction & .5601 \\
Moral-ethical-self-satisfaction & .6075 \\
Personal-self-satisfaction & .6105 \\
Family-self-satisfaction & .6124 \\
Social-self-satisfaction & .6408 \\
& .6349 \\
Physical-behavior & .5786 \\
Moral-ethical-behavior & .6667 \\
Personal-behavior & .5967 \\
Family-behavior & .4678 \\
Social-behavior & .6230 \\
Academic & $.8742 *$ \\
\hline
\end{tabular}

*The academic self-concept component consists of elght items. 
alpha, measuring internal consistency (Lord \& Norwick, 1968, p. 89). Each subcomponent scale consists of slx items. The lowest reliability coefficient is .4678 for the family-behavior subcomponent and the highest is .7100 for family-identity subcomponents. For scales which have as few as six items, the reliability coefficients are satisfactory when compared to the component scales of fifteen items which range from .8000 to .9000 (Fitts, 1965, p. 14).

Means on subcomponents, components, and dimensions

In this section the means of the data for all hypotheses are summarized and presented. These subjective comparisons will be tested for significance and recorded when testing the hypotheses. The reader groups on which these means were calculated are males and females and respondents at universities, community colleges, and continuingeducation institutions.

Male respondents. Table 5 presents the means of the subcomponents, components, and dimensions of self-concept for male readers. of the subcomponents of self-concept, the highest mean score of the inadequate readers is 25.09 for physical-identity self-concept while the lowest is 19.77 for personal-behavior self-concept. The highest mean score for adequate readers is 26.28 for family-identity self-concept and the lowest mean score is 19.98 for personal-behavior self-concept.

Examination of subcomponent cells (table 5) indicates that several mean scores are higher for inadequate readers: physicalidentity, physical-self-satisfaction, physical-behavior, and socialself-satisfaction. In addition, personal-self-satisfaction mean scores 
TABLE 5

MEANS OF COMPONENTS, DIMENSIONS, AND SUBCOMPONENTS OF SELF-CONCEPT FOR INADEQUATE AND ADEQUATE MALE READERS

\begin{tabular}{|c|c|c|c|c|c|c|c|}
\hline \multirow{2}{*}{$\begin{array}{l}\text { Dimensions } \\
\text { of Self- } \\
\text { Concept }\end{array}$} & \multirow{2}{*}{$\begin{array}{l}\text { Type of } \\
\text { Readers }\end{array}$} & \multicolumn{5}{|c|}{ Components of Self-Concept } & \multirow{2}{*}{$\begin{array}{c}\text { Total } \\
\text { Dimensions }\end{array}$} \\
\hline & & Physical & $\begin{array}{l}\text { Moral- } \\
\text { Ethical }\end{array}$ & Persona1 & Family & Social & \\
\hline \multirow{2}{*}{ Identity } & Inadequate & 25.09 & 24.20 & 24.32 & 24.96 & 23.50 & 122.06 \\
\hline & Adequate & 24.90 & 24.87 & 24.52 & 26.28 & 23.79 & 124.36 \\
\hline \multirow{2}{*}{$\begin{array}{l}\text { Self- } \\
\text { satisfaction }\end{array}$} & Inadequate & 20.62 & 19.91 & 19.94 & 19.87 & 21.09 & 101.43 \\
\hline & Adequate & 20.50 & 20.85 & 19.98 & 20.40 & 20.52 & 102.26 \\
\hline \multirow{2}{*}{ Behavior } & Inadequate & 22.75 & 21.34 & 19.77 & 21.28 & 21.47 & 106.61 \\
\hline & Adequate & 22.27 & 22.23 & 20.15 & 22.03 & 21.97 & 108.63 \\
\hline \multirow{2}{*}{$\begin{array}{l}\text { Total } \\
\text { Components }\end{array}$} & Inadequate & 68.46 & 65.45 & 64.03 & 66.10 & 66.06 & $330.10^{*}$ \\
\hline & Adequate & 67.68 & 67.95 & 64.65 & 68.70 & 66.28 & $335.25 *$ \\
\hline
\end{tabular}

*Total Subcomponents 
are almost equal. Of the components of self-concept, however, the inadequate readers have a higher physical self-concept than the adequate readers. Of the component means, the highest mean score is 68.46 on the physical self-concept component for male inadequate readers. The highest mean score for the male adequate readers is 68.70 on the family-self-concept component.

On the dimensions of self-concept, the mean scores of the maleadequate readers are higher than the male inadequate readers. For both groups the means of the dimensions, in rank order, are identity, behavior, self-satisfaction.

Female respondents. Table 6 presents means of subcomponents, components, and dimensions of self-concept for female readers. Of the subcomponent cells, the highest mean score of inadequate readers is 24.91 for family-identity self-concept while the lowest mean score is 19.60 for family-self-satisfaction. The highest mean score of adequate readers is 26.17 for family-identity and the lowest mean score is 20.11 for persona1-self-satisfaction.

For all the subcomponent cells, the mean scores of female adequate readers are higher than those of the female inadequate readers, except for physical-identity and physical-self-satisfaction.

The female adequate readers have a higher mean score in all the components and dimensions of self-concept. However, the physical self-concept component mean score for female inadequate readers (67.99) is nearly equal to that of female adequate readers. The rank order of the dimensions of self-concept for inadequate and adequate female readers is identity, behavior, and self-satisfaction. 
TABLE 6

MEANS OF COMPONENTS, DIMENSIONS, AND SUBCOMPONENTS OF SELF-CONCEPT FOR INADEQUATE AND ADEQUATE FEMALE READERS

\begin{tabular}{|c|c|c|c|c|c|c|c|}
\hline \multirow{2}{*}{$\begin{array}{l}\text { Dimensions } \\
\text { of Self- } \\
\text { Concept }\end{array}$} & \multirow{2}{*}{$\begin{array}{l}\text { Type of } \\
\text { Readers }\end{array}$} & \multicolumn{5}{|c|}{ Components of Self-Concept } & \multirow{2}{*}{$\begin{array}{c}\text { Total } \\
\text { Dimensions }\end{array}$} \\
\hline & & Physical & Ethical & Personal & Family & Soc1al & \\
\hline \multirow{2}{*}{ Identity } & Inadequate & 24.50 & 24.15 & 24.35 & 24.91 & 23.64 & 121.55 \\
\hline & Adequate & 24.98 & 25.15 & 25.16 & 26.17 & 23.96 & 125.42 \\
\hline \multirow{2}{*}{$\begin{array}{l}\text { Self- } \\
\text { satisfaction }\end{array}$} & Inadequate & 20.63 & 19.88 & 20.04 & 19.60 & 20.72 & 100.86 \\
\hline & Adequate & 20.46 & 21.53 & 20.11 & 20.60 & 21.64 & 104.34 \\
\hline \multirow{2}{*}{ Behavior } & Inadequate & 22.87 & 21.73 & 20.11 & 21.13 & 21.76 & 107.60 \\
\hline & Adequate & 22.66 & 22.72 & 20.48 & 22.44 & 22.92 & 111.22 \\
\hline \multirow{2}{*}{$\begin{array}{l}\text { Total } \\
\text { components }\end{array}$} & Inadequate & 67.99 & 65.76 & 64.50 & 65.64 & 66.12 & $330.02 *$ \\
\hline & Adequate & 68.10 & 69.40 & 65.75 & 69.22 & 68.52 & $340.98 *$ \\
\hline
\end{tabular}

*Total subcomponents 
The mean scores seem to reveal a greater discrepancy between the female inadequate and adequate readers than between male inadequate and adequate readers.

University respondents. Table 7 presents the subcomponents, components, and dimensions of self-concept for respondents at the universities. Of the subcomponent cells, the highest mean score of inadequate readers is 24.91 for family-identity and the lowest is 19.66 for family-self-satisfaction. The highest mean score of adequate readers is 26.17 for family-identity and the lowest is 20.11 for personal self-satisfaction. All of the self-concept subcomponent scores of adequate readers are higher than the mean scores for inadequate readers, except for physical-identity, physical self-satisfaction, physical-behavior, personal-self-satisfaction, and social-behavior.

The inadequate readers at the university have three higher mean scores in the components of self-concept: physical self-concept, $(69.81$ to 68.52$)$, social self-concept (65.37 to 65.08$)$, and personal self-concept (69.81 to 68.52$)$. In the identity dimension, the inadequate readers at universities have a mean score of 125.49 while the adequate readers have a mean score of 125.26 .

Community college respondents. Table 8 presents the means of subcomponents, components, and dimensions of self-concept for respondents at community colleges. Of the subcomponent cells, the inadequate readers reached a high mean score of 24.65 for family-identity and a low mean score of 19.62 for physical-self-satisfaction. The adequate readers reached a high mean of 25.67 for family-identity and a low mean of 19.91 for family-self-satisfaction. 
TABLE 7

MEANS OF COMPONENTS, DIMENSIONS, AND SUBCOMPONENTS OF SELF-CONCEPT FOR INADEQUATE AND ADEQUATE READERS AT THE UNIVERSITIES

\begin{tabular}{|c|c|c|c|c|c|c|c|}
\hline \multirow{2}{*}{$\begin{array}{l}\text { Dimensions } \\
\text { of Self- } \\
\text { Concept }\end{array}$} & \multirow{2}{*}{$\begin{array}{l}\text { Type of } \\
\text { Readers }\end{array}$} & \multicolumn{5}{|c|}{ Components of Self-Concept } & \multirow{2}{*}{$\begin{array}{c}\text { Total } \\
\text { Dimensions }\end{array}$} \\
\hline & & Physical & $\begin{array}{l}\text { Moral- } \\
\text { Ethical }\end{array}$ & Personal & Family & Social & \\
\hline \multirow{2}{*}{ Identity } & Inadequate & 25.30 & 25.31 & 24.71 & 26.08 & 24.09 & 125.49 \\
\hline & Adequate & 25.09 & 25.18 & 24.85 & 26.41 & 23.73 & 125.26 \\
\hline \multirow{2}{*}{$\begin{array}{l}\text { Self- } \\
\text { satisfaction }\end{array}$} & Inadequate & 21.24 & 19.80 & 20.30 & 19.73 & 20.86 & 101.93 \\
\hline & Adequate & 20.73 & 20.81 & 19.85 & 20.96 & 20.73 & 103.08 \\
\hline \multirow{2}{*}{ Behavior } & Inadequate & 23.27 & 22.29 & 20.36 & 21.74 & 22.12 & 109.78 \\
\hline & Adequate & 22.70 & 22.64 & 20.38 & 22.39 & 22.49 & 110.60 \\
\hline \multirow{2}{*}{$\begin{array}{l}\text { Total } \\
\text { components }\end{array}$} & Inadequate & 69.81 & 67.40 & 65.37 & 67.55 & 67.07 & $337.20 *$ \\
\hline & Adequate & 68.52 & 68.63 & 65.08 & 69.76 & 66.95 & $338.94 *$ \\
\hline
\end{tabular}

*Total subcomponents 
TABLE 8

MEANS OF COMPONENTS, DIMENSIONS, AND SUBCOMPONENTS OF SELF-CONCEPT FOR INADEQUATE AND ADEQUATE READERS AT THE COMMUNITY COLLEGES

\begin{tabular}{|c|c|c|c|c|c|c|c|}
\hline \multirow{2}{*}{$\begin{array}{l}\text { Dimensions } \\
\text { of Self- } \\
\text { Concept }\end{array}$} & \multirow{2}{*}{$\begin{array}{l}\text { Type of } \\
\text { Readers }\end{array}$} & \multicolumn{5}{|c|}{ Components of Self-Concept } & \multirow{2}{*}{$\begin{array}{c}\text { Total } \\
\text { Dimensions }\end{array}$} \\
\hline & & Physical & Ethical & Personal & Family & Social & \\
\hline \multirow{2}{*}{ Identity } & Inadequate & 24.81 & 24.12 & 24.32 & 24.65 & 23.51 & 121.41 \\
\hline & Adequate & 24.51 & 24.68 & 24.69 & 25.67 & 24.51 & 124.06 \\
\hline \multirow{2}{*}{$\begin{array}{l}\text { Self- } \\
\text { satisfaction }\end{array}$} & Inadequate & 19.62 & 20.01 & 19.94 & 20.25 & 21.60 & 101.42 \\
\hline & Adequate & 20.00 & 21.79 & 20.09 & 19.91 & 21.75 & 103.54 \\
\hline \multirow{2}{*}{ Behavior } & Inadequate & 22.57 & 21.40 & 20.05 & 21.10 & 21.70 & 106.82 \\
\hline & Adequate & 22.55 & 22.17 & 20.15 & 21.92 & 22.92 & 109.71 \\
\hline \multirow{2}{*}{$\begin{array}{l}\text { Total } \\
\text { components }\end{array}$} & Inadequate & 67.00 & 65.53 & 64.31 & 66.00 & 66.81 & $329.65 *$ \\
\hline & Adequate & 67.06 & 68.64 & 64.93 & 67.50 & 69.18 & $337.31 *$ \\
\hline
\end{tabular}

*Total subcomponents 
Continuing-education respondents. Table 9 presents the means of subcomponents, components, and dimensions of self-concept for respondents from continuing-education institutions. The adequate readers have a higher self-concept in all subcomponents except for a slight reversal in the physical-self-satisfaction subcomponent. And as expected the mean scores of the components and dimensions for adequate readers are greater than the mean scores for inadequate readers. Of the subcomponent cells, the highest mean score is 26.52. for family-identity of inadequate readers and the lowest 18.99 for personal-behavior of inadequate readers. of the subcomponent cells inadequate readers reached the high mean score of 23.29 on physical-identity. and a low mean score of 18.99 for personal behavior. The highest mean score for adequate readers reached 26.52 on the family-identity and a low mean-score of 20.44 each, for personal-self-satisfaction and family-self-satisfaction.

Data from tables 5 through 9 indicate that the self-concept mean scores of adequate readers are generally higher than those of inadequate readers. However, inadequate readers generally score higher on at least the one subcomponent of physical self-concept.

The rank order of the three dimensions of self-concept, as shown in tables 5 through 9, is identity, behavior, and selfsatisfaction.

Means on total test

The means of self-concept of inadequate- and adequate-reader groups is presented in table 10. The groups represented in this section for both the inadequate- and adequate-readers were categorized according to: sex-male and female; race--white and black; age groups--undertwenty, twenty-one-to-thirty, and over-thirty; type of educational 
TABLE 9

MEANS OF COMPONENTS, DIMENSIONS, AND SUB-COMPONENTS OF SELF-CONCEPT FOR INADEQUATE AND ADEQUATE READERS AT THE CONTINUING-EDUCATION INSTITUTIONS

\begin{tabular}{|c|c|c|c|c|c|c|c|}
\hline \multirow{2}{*}{$\begin{array}{l}\text { Dimensions } \\
\text { of Self- } \\
\text { Concept }\end{array}$} & \multirow{2}{*}{$\begin{array}{l}\text { Type of } \\
\text { Readers }\end{array}$} & \multicolumn{5}{|c|}{ Components of Self-Concept } & \multirow{2}{*}{$\begin{array}{c}\text { Total } \\
\text { Dimensions }\end{array}$} \\
\hline & & Physical & $\begin{array}{l}\text { Moral- } \\
\text { Ethica1 }\end{array}$ & Personal & Eamily. & Soclal & \\
\hline \multirow{2}{*}{ Identity } & Inadequate & 23.99 & 22.01 & 23.62 & 23.07 & 22.56 & 115.25 \\
\hline & Adequate & 25.18 & 25.22 & 25.26 & 26.52 & 23.66 & 125.84 \\
\hline \multirow{2}{*}{$\begin{array}{l}\text { Self- } \\
\text { satisfaction }\end{array}$} & Inadequate & 20.56 & 19.85 & 19.40 & 19.18 & 20.25 & 99.24 \\
\hline & Adequate & 20.52 & 21.58 & 20.44 & 20.44 & 21.44 & 104.41 \\
\hline \multirow{2}{*}{ Behavior } & Inadequate & 22.15 & 20.12 & 18.99 & 20.29 & 20.51 & 102.06 \\
\hline & Adequate & 22.30 & 22.74 & 20.55 & 22.49 & 22.23 & 110.32 \\
\hline \multirow{2}{*}{$\begin{array}{l}\text { Total } \\
\text { components }\end{array}$} & Inadequate & 66.70 & 61.98 & 62.01 & 62.54 & 63.32 & $316.55 *$ \\
\hline & Adequate & 68.00 & 69.54 & 66.25 & 69.45 & 67.33 & $340.57 *$ \\
\hline
\end{tabular}

*Total subcomponents 
TABLE 10

MEANS OF SELF-CONCEPT OF INADEQUATE AND ADEQUATE READER GROUPS

\begin{tabular}{|c|c|c|c|c|c|}
\hline \multirow[b]{2}{*}{ Category } & \multirow{2}{*}{ Group } & \multicolumn{2}{|c|}{ Inadequate } & \multicolumn{2}{|c|}{ Adequate } \\
\hline & & $\mathrm{n}$ & Mean & $\mathrm{n}$ & Mean \\
\hline \multirow{2}{*}{ Sex } & Male & 156 & 330.10 & 115 & 335.26 \\
\hline & Female & 123. & 330.01 & 166 & 340.98 \\
\hline \multirow{2}{*}{ Race } & White & 194 & 325.76 & 247 & 338.44 \\
\hline & Black & 64 & 338.14 & $23:$ & 346.00 \\
\hline \multirow{3}{*}{ Age group } & Under 20 & 150 & 329.19 & 140 & 340.73 \\
\hline & $21-30$ & 89 & 335.07 & 92 & 337.92 \\
\hline & Over 30 & 40 & 324.67 & 47 & 336.11 \\
\hline \multirow{3}{*}{$\begin{array}{l}\text { Type of } \\
\text { educational } \\
\text { institution }\end{array}$} & $\begin{array}{l}\text { Universi- } \\
\text { ties }\end{array}$ & 132 & 337.22 & 135 & 338.93 \\
\hline & $\begin{array}{l}\text { Community } \\
\text { colleges }\end{array}$ & 77 & 329.65 & 75 & 337.29 \\
\hline & $\begin{array}{l}\text { Continuing- } \\
\text { education } \\
\text { institutions }\end{array}$ & 68. & 316.54 & 73 & 340.56 \\
\hline Total & & $n=283$ & 330.34 & $n=286$ & 338.94 \\
\hline Combined & & $N=569$ & & 34.62 & \\
\hline
\end{tabular}


Institution--university, community college, continuing-education. The total number of cases in the inadequate group was 283 , whlle the total in the adequate group was 286 . Due to clerical errors in demographic data, the totals of the different categortes are unequal. For example a female respondent may have placed a slash in line three instead of line two, which was designated for female respondents. According to table 10, all adequate-group means in all categories are larger than the corresponding inadequate-group means. Therefore, the total adequate-group mean is also higher than the inadequate-group mean.

As for sex, the male inadequate readers reached an almost equal mean of 330.10 as did the female inadequate group, 330.01 . However, there seems to be a larger disparity between the means of the adequate male $(335.26)$ and female readers $(340.98)$.

Concerning race, the mean self-concept of black inadequate and the mean self-concept of black adequate readers are larger than the corresponding groups of white readers. The black inadequate group attained a mean of 338.14 which is almost equal to the mean 338.44 of the white adequate reader group.

\section{Testing the Hypotheses}

The data have been presented. In this section the data will be analyzed by testing the hypotheses in three major categories in the order of the hypotheses.

The first section deals with the comparison of self-concept means on the total test compared to the norm in the TSCS. The second section deals with the comparison of self-concept centrolds of 
components, and dimensions with the norms of the TSCS. The final section deals with a comparison of the self-concept of inadequate and adequate readers by discriminant analysis.

\section{Means on total test compared} to norm

The comparison of total self-concept means against the population norm (345.57) as it concerns hypotheses 1 and 2 is presented in table 11. To test the significance of the differences the $z$-test was used. This test compares a single sample mean to a population mean with a known population variance. Table 11 presents the categories, groups, z-scores, and the probabilty for inadequate and adequate readers. An asterisk in the probability column indicates that the corresponding group mean is significantly different from the norm (Fitts, 1965, p. 14). These are all significantly lower than the normal population.

The self-concept means of inadequate male and adequate male readers were significantly different from the normal population. There also is a significant difference between the female inadequate readers and the norm group, but the female adequate readers are not significantly different.

According to race, the white inadequate and the white adequate readers are both significantly different from the population norm as shown in table 11. The self-concept means of the black readers are not significantly different from the population norm.

According to age grouping, the inadequate readers in the under-twenty group and the over-thirty group are significantly different from the normal population... Among the adequate readers, however, 
TABLE 11

COMPARISON OF TOTAL TEST MEANS AGAINST

POPULATION NORM (345.57)

\begin{tabular}{|c|c|c|c|c|c|}
\hline \multirow{2}{*}{ Category } & \multirow{2}{*}{ Group } & \multicolumn{2}{|c|}{ Inadequate } & \multicolumn{2}{|c|}{ Adequate } \\
\hline & & Z-Score & Probability & $\mathrm{Z}-\mathrm{S}$ core & Probability \\
\hline \multirow[b]{2}{*}{ Sex } & Male & -6.29 & $<.0005^{*}$ & -3.60 & $<.0005 *$ \\
\hline & Female & -5.62 & $<.0005 *$ & -1.93 & .054 \\
\hline \multirow[b]{2}{*}{ Race } & White & -8.99 & $<.0005 *$ & -3.65 & $<.0005 *$ \\
\hline & Black & -1.94 & .054 & .07 & .946 \\
\hline \multirow{3}{*}{ Age group } & Under 20 & -6.54 & $<.0005 *$ & -1.87 & .062 \\
\hline & $21-30$ & -3.23 & $.002 *$ & -2.39 & $.018 *$ \\
\hline & Over 30 & $-4 \cdot 30$ & $<.0005 *$ & -2.11 & $.036 *$ \\
\hline \multirow{3}{*}{$\begin{array}{l}\text { Type of } \\
\text { educational } \\
\text { institution }\end{array}$} & Universities & -3.13 & $.002 *$ & -2.51 & $.012 *$ \\
\hline & $\begin{array}{r}\text { Community } \\
\text { colleges }\end{array}$ & -4.55 & $<.0005 *$ & -2.33 & $.020 *$ \\
\hline & $\begin{array}{l}\text { Continuing- } \\
\text { education } \\
\text { institutions }\end{array}$ & -7.80 & $<.0005 x$ & -1.39 & .164 \\
\hline Total & & -8.35 & $.0005 *$ & -3.65 & $.0005 *$ \\
\hline
\end{tabular}

*Significant at the .05 level. 
the twenty-one-to-thirty group and the over-thirty group have signifIcantly different means from the normal population.

According to type of Institution, the means of both the Inadequate and adequate readers at the universities and communty colleges are signiflcantly different from the population norm. The mean of the inadequate readers at the continuing-education institutions, but not that of the adequate readers, is significantly different from the normal population.

The means of the inadequate- and adequate-reader total groups are significantly different from the norm group. All the groups whose means are significantly different from the normal population, as shown in table 11, have lower means than the normal population.

Comparison of the centroids to population norms

Hypotheses 3 through 6 are concerned with the centroid of the components of self-concept and the centroid of the dimensions of selfconcept and their comparison with the normal population of the TSCS (Fitts, 1965, p. 14).

Components. In table 12 the centroids of the components of self-concept of inadequate and adequate readers are compared with the centroid of the normal population as described in the TSCS (Fitts, 1965, p. 14).

The comparison of the centroid of inadequate readers to the norm population yields an F-ratio of 38.313 with 5 and 278 degrees of freedom and a significant probability of less than .005. The centroid of the components of self-concept for inadequate readers is significantly different from the centroid of the normal population. 
TABLE 12

COMPARISON ON THE CENTROIDS OF

COMPONENTS OF SELF-CONCEPT

\begin{tabular}{|c|c|c|c|c|c|c|c|c|}
\hline & \multicolumn{5}{|c|}{ Centroids of the Components } & \multirow{2}{*}{ F-Ratio } & \multirow{2}{*}{$\mathrm{DF}$} & \multirow{2}{*}{$\begin{array}{l}\text { Proba- } \\
\text { bility }\end{array}$} \\
\hline & Phystcal & Moral-ethical & Personal & Fam11y & Social & & & \\
\hline $\begin{array}{l}\text { Normal } \\
\text { population }\end{array}$ & 71.78 & 70.33 & 64.55 & 70.83 & 68.14 & & & \\
\hline $\begin{array}{l}\text { Inadequate } \\
\text { readers }\end{array}$ & 68.33 & 65.63 & 64.29 & 65.99 & 66.11 & 38.313 & $5 \& 278$ & $<.005$ \\
\hline $\begin{array}{l}\text { Adequate } \\
\text { readers }\end{array}$ & 67.97 & 68.89 & 65.34 & 69.09 & 67.65 & 26.107 & $5 \& 281$ & $<.005$ \\
\hline
\end{tabular}


The centroid of the sample of adequate readers has an F-ratio of 26.107 with 5 and 281 degrees of freedom and a significant probability of less than .005 . The centroid of the components of selfconcept for adequate readers is significantly different from the centroid of the normal population. The personal self-concept component of adequate readers is slightly higher while their other components are somewhat lower than those of the norm group.

Considering the normal population means and the two sample means, table 12 reveals that the normal population.means are highest, the adequate-reader sample means rank second, and the inadequatereader sample means are lowest with one exception--the physical selfconcept component mean is higher for inadequate readers than the corresponding mean for the adequate readers.

Dimensions. Table 13 compares the centroid of inadequate readers to the norm population yielding an F-ratio of 44.074 and 3 and 280 degrees of freedom and a significant probability of less than .005 . The centroid of the dimensions of self-concept for adequate readers is significantly different from the centroid of the normal population.

The centroid of the sample of adequate readers has an F-ratio of 24.171 with 3 and 283 degrees of freedom and a significant probability of less than .005. The centroid for the dimensions of selfconcept for adequate readers is significantly different from the centroid of the normal population. 
TABLE 13

COMPARISON ON THE CENTROIDS OF DIMENSIONS OF SELF-CONCEPT

\begin{tabular}{|c|c|c|c|c|c|c|}
\hline & \multicolumn{3}{|c|}{ Centroids of Dimensions } & \multirow{2}{*}{ F-Ratio } & \multirow{2}{*}{$\mathrm{DF}$} & \multirow{2}{*}{$\begin{array}{l}\text { Proba- } \\
\text { bility }\end{array}$} \\
\hline & Identity & Self-satisfaction & Behavior & & & \\
\hline $\begin{array}{l}\text { Normal } \\
\text { population }\end{array}$ & 127.10 & 103.67 & 115.01 & & & \\
\hline $\begin{array}{l}\text { Inadequate } \\
\text { readers }\end{array}$ & 121.91 & 101.25 & 107.17 & 44.074 & $3 \& 280$ & $\therefore<.005$ \\
\hline $\begin{array}{l}\text { Adequate } \\
\text { readers }\end{array}$ & 125.10 & 103.60 & 110.24 & 24.171 & $3 \& 283$ & $<.005$ \\
\hline
\end{tabular}


For both hypotheses, all three dimensions are lower than the norm population.

\section{Discriminant analysis}

The data on hypotheses 7 through 9 were subjected to discriminant analysis to determine the relative weights of the dimensions, the components, and the subcomponents of the self-concept to best separate the Inadequate and adequate readers.

The computer program for simple discriminant analysis "computes optimal weighting coefficients that provide maximum separation between two groups" (Overall and Klett, 1972, p. 275). The relative weight magnitudes may then be ranked from the largest positive or negative weights.

Dimensions. Table 14 presents the discriminant function analysis of the dimensions of self-concept for inadequate and adequate male readers. For the test of significance of this discriminant

TABLE 14

DISCRIMINANT FUNCTION ANALYSIS OF THE DIMENSIONS OF SELF-CONCEPT

FOR INADEQUATE AND ADEQUATE

MALE READERS

\begin{tabular}{lcc}
\hline $\begin{array}{c}\text { Self-Concept } \\
\text { Dimension }\end{array}$ & $\begin{array}{c}\text { Standard } \\
\text { Weight }\end{array}$ & Rank \\
\hline Identity & .79 & 1 \\
$\begin{array}{l}\text { Self- } \\
\text { satisfaction }\end{array}$ & -.50 & 3 \\
Behavior & .55 & 2 \\
\hline
\end{tabular}


function, chi-square is 3.06 with 3 degrees of freedom and a probablility of .3830 . The discriminant function does not signif1cantly separate the inadequate from the adequate readers.

Table 15 presents the discriminant function analysis of the dimensions of self-concept for inadequate and adequate female readers. To test the significance of this discriminant function, the chisquare is 7.8 with 3 degrees of freedom and a probability of .0503 . This discriminant function does not significantly separate the inadequate and adequate readers, although it is approaching significance.

TABLE 15

DISCRIMINANT FUNCTION ANALYSIS OF

THE DIMENSTONS OF SELF-CONCEPT

FOR INADEQUATE AND ADEQUATE

FEMALE READERS

\begin{tabular}{lcc}
\hline $\begin{array}{l}\text { Self-Concept } \\
\text { Dimension }\end{array}$ & $\begin{array}{l}\text { Standard } \\
\text { Weight }\end{array}$ & Rank \\
\hline $\begin{array}{l}\text { Identity } \\
\begin{array}{l}\text { Self- } \\
\text { satisfaction }\end{array}\end{array}$ & .676 & 1 \\
Behavior & .002 & 3 \\
\hline
\end{tabular}

Table 16 presents the discriminant function analysis of the dimensions of self-concept for inadequate and adequate readers at the universities. For the test of significance of this discriminant function, chi-square is .97 with 3 degrees of freedom and a probability of 80.78 . This discriminant function does not significantly separate the Inadequate and adequate groups of female readers. 
TABLE 16
DISCRIMINANT FUNCTION ANALYSIS OF THE
DIMENSIONS OF SELF-CONCEPT FOR
INADEQUATE AND ADEQUATE
READERS AT THE
UNIVERSITIES

\begin{tabular}{lcc}
\hline $\begin{array}{l}\text { Self-Concept } \\
\text { Component }\end{array}$ & $\begin{array}{l}\text { Standard } \\
\text { Weight }\end{array}$ & Rank \\
\hline $\begin{array}{l}\text { Identity } \\
\text { Self- } \\
\text { satisfaction }\end{array}$ & -.95 & 1 \\
\begin{tabular}{l} 
Behavior \\
\hline
\end{tabular}
\end{tabular}

Table 17 presents the discriminant function analysis of the dimensions of self-concept for inadequate and adequate readers at the community colleges. For the test of significance of this discriminant function, chi-square is 2.30 with 3 degrees of freedom and a probability of .5210 . The discriminant function does not significantly separate the two groups at the community colleges.

TABLE 17

DISCRIMINANT FUNCTION ANALYSIS OF THE DIMENSIONS

OF SELF-CONCEPT FOR INADEQUATE AND ADEQUATE READERS AT COMMUNITY COLLEGES

\begin{tabular}{lcc}
\hline $\begin{array}{l}\text { Self-Concept } \\
\text { Dimension }\end{array}$ & $\begin{array}{l}\text { Standard } \\
\text { Weight }\end{array}$ & Rank \\
\hline $\begin{array}{l}\text { Identity } \\
\text { Self- } \\
\text { satisfaction }\end{array}$ & .50 & $\cdot 2$ \\
Behavior & -.36 & 3 \\
\hline
\end{tabular}


Table 18 presents the discriminant analysis of the dimensions of self-concept for inadequate and adequate readers at the continuing-education institutions. For the test of significance of this discriminant function, the chi-square is 27.28 with 3 degrees of freedom and a probability of less than .005 . Thus the discriminant function significantly separates inadequate from adequate readers at the continuing-education institutions.

Only those weights which are at least fifty percent of the maximun weight, in any function are considered and marked with asterisks (*) in the tables. This discriminant function is denoted by increasing identity. For this function, the mean for inadequate readers is 8.89 and for adequate readers is 9.77 .

TABLE 18

DISCRIMINANT FUNCTION ANALYSIS

OF THE DIMENSIONS OF SELF-CONCEPT

FOR INADEQUATE AND ADEQUATE READERS

AT CONTINUING-EDUCATION INSTITUTIONS

\begin{tabular}{lcc}
\hline $\begin{array}{l}\text { Self-Concept } \\
\text { Dimension. }\end{array}$ & $\begin{array}{l}\text { Standard } \\
\text { Weight }\end{array}$ & Rank \\
\hline $\begin{array}{l}\text { Identity } \\
\begin{array}{l}\text { Self- } \\
\text { satisfaction }\end{array}\end{array}$ & .937 & $1 *$ \\
Behavior & .333 & 2 \\
\hline
\end{tabular}

*The relative weight values considered are at 1 east $50 \%$ of the highest weight. 
The discriminant function analysts of the dimensions of selfconcept for inadequate and adequate readers on five categories of readers is presented in tables 14 through 18. Applying the chi-square test for the significance of difference in the discriminant function means of the two groups, four categories of readers fail to show significant differences between inadequate and adequate readers on the discriminant function.

The continuing-education category of readers shows a significant difference for the discriminant function. This discriminant function is denoted by an increasing weight of the identity dimension from inadequate to adequate readers.

Components. Table 19 presents the discriminant function analysis of the components of self-concept of inadequate and adequate

TABLE 19

DISCRIMINANT FUNCTION ANALYSIS

OF THE COMPONENTS OF SELF-CONCEPT

OF INADEQUATE AND ADEQUATE MALE READERS

\begin{tabular}{lcc}
\hline $\begin{array}{l}\text { Self-Concept } \\
\text { Component }\end{array}$ & $\begin{array}{l}\text { Standard } \\
\text { Weight }\end{array}$ & Rank \\
\hline $\begin{array}{l}\text { Physical } \\
\text { Moral- } \\
\text { ethical }\end{array}$ & -.51 & $2 *$ \\
$\begin{array}{l}\text { Personal } \\
\text { Family }\end{array}$ & .42 & $4 *$ \\
$\begin{array}{l}\text { Social } \\
\text { Academic }\end{array}$ & -.19 & 6 \\
\hline $\begin{array}{l}\text { *The relative weight values considered are } \\
\text { at least 50\% of the highest weight. }\end{array}$ & 5 \\
\hline
\end{tabular}


male readers. For the test of significance of this discriminant function, chi-square is 28.49 with 6 degrees of freedom and a probability less than .001. This discriminant function significantly separates the inadequate from the adequate readers.

This function is denoted in descending order of importance by increasing academic self-concept and by decreasing physical self-concept and by increasing family and moral-ethical self-concepts. On this discriminant function the mean for inadequate readers is 3.06 and for adequate readers is 3.71 . For the components and subcomponents a graphical illustration of the discriminant function is given in appendix $F$.

Table 20 presents the discriminant function analysis of the components of self-concept of inadequate and adequate female

TABLE 20

DISCRIMINANT FUNCTION ANALYSIS

OF THE COMPONENTS OF SELF-CONCEPT OF

INADEQUATE AND ADEQUATE FEMALE READERS

Self-Concept Component

\section{Physical}

Moral-

ethical

Personal

Family

Social

Academic
Standard Weight
Rank

*The relative weight values considered are at 1 east $50 \%$ of the highest weight. 
readers. For the test of significance of this discriminant function, chi-square is 49.24 with 6 degree of freedom and a probability of less than .0005 . This discriminant function significantly separates the inadequate and adequate readers.

This function is denoted in descending order of importance by increasing academic self-concept, decreasing personal self-concept, and increasing moral-ethical self-concept. On this discriminant function the mean for inadequate readers is 5.28 and for adequate readers is 6.12 .

Table 21 presents the discriminant function analysis of the components of self-concept of inadequate and adequate readers

TABLE 21.

DISCRIMINANT FUNCTION ANALYSIS

OF THE COMPONENTS OF SELF-CONCEPT

OF INADEQUATE AND ADEQUATE READERS

AT THE UNIVERSITIES

\begin{tabular}{lcc}
\hline $\begin{array}{l}\text { Self-Concept } \\
\text { Component }\end{array}$ & $\begin{array}{l}\text { Standard } \\
\text { Weight }\end{array}$ & Rank \\
\hline Physical & -.41 & 4 \\
$\begin{array}{l}\text { Moral- } \\
\text { ethical }\end{array}$ & .35 & 5 \\
Personal & -.63 & $2 *$ \\
Family & .43 & 3 \\
Social & .04 & 6 \\
Academic & .90 & $1 *$ \\
\hline
\end{tabular}

* The relative weight values considered are at least $50 \%$ of the highest weight. 
at the universities. For the test of significance of this discriminant function, chi-square is 44.52 with 6 degrees of freedom and a probability of less than .0005 . This discriminant function significantly separates inadequate from adequate readers.

This function is denoted in descending order of importance, by increasing academic self-concept and decreasing personal selfconcept. On this function the mean for inadequate readers is 2.80 and for adequate readers is 3.62 .

Table 22 presents the discriminant function analysis of the components of self-concept of inadequate and adequate readers at the community colleges. For the test of significance of this

TABLE 22

DISCRIMINANT FUNCTIONS ANALYSIS

OF THE COMPONENTS OF SELF-CONCEPT OF

INADEQUATE AND ADEQUATE READERS

AT COMMUNITY COLLEGES

\begin{tabular}{lcc}
\hline $\begin{array}{l}\text { Self-Concept } \\
\text { Component }\end{array}$ & $\begin{array}{l}\text { Standard } \\
\text { Weight }\end{array}$ & Rank \\
\hline $\begin{array}{l}\text { Physical } \\
\text { Moral- } \\
\text { ethical }\end{array}$ & -.43 & $3 *$ \\
Personal & .35 & 5 \\
Family & -.36 & 4 \\
Social & -.01 & 6 \\
Academic & .60 & $2 *$ \\
\hline
\end{tabular}

* The relative weight values considered are at least $50 \%$ of the highest weight. 
discriminant function, chi-square is 16.08 with 6 degrees of freedom and a probability of .0133 . This discriminant function significantly separates inadequate from adequate réaders.

This function is denoted, in descending order of importance, by increasing academic self-concept, increasing social self-concept, and decreasing physical self-concept. On this discriminant function the mean for inadequate readers is 6.88 and for adequate readers is 7.53 .

Table 23 presents the discriminant function analysis of the components of self-concept of inadequate and adequate readers at. the continuing-education institutions. For the test of significance

\section{TABLE 23}

DISCRIMINANT FUNCTION ANALYSIS

OF THE COMPONENTS OF SELF-CONCEPT OF

INADEQUATE AND ADEQUATE READERS

AT THE CONTINUING-EDUCATION INSTITUTIONS

\begin{tabular}{lcc}
\hline $\begin{array}{l}\text { Self-Concept } \\
\text { Component }\end{array}$ & $\begin{array}{l}\text { Standard } \\
\text { Weight }\end{array}$ & Rank \\
\hline Physical & -.48 & $2 *$ \\
$\begin{array}{l}\text { Moral- } \\
\text { ethical }\end{array}$ & .69 & $1 *$ \\
Personal & .21 & 5 \\
Family & .23 & 4 \\
Social & -.05 & 6 \\
Academic & .44 & $3 *$ \\
\hline
\end{tabular}

*The relative weight values considered are at 1 east $50 \%$ of the highest weight. 
of this discriminant function, the chi-square is 39.44 with 6 degrees of freedom and probability of less than .0005 .

This discriminant function is denoted, in descending order of importance, by an increasing moral-ethical self-concept, a descreasing physical self-concept, and increasing academic selfconcept. On this function the mean for inadequate readers is 5.91 and for adequate readers is. 6.97. This discriminant function significantly separates inadequate from adequate readers.

Tables 19 through 23 present data on the discriminant analysis of the components of self-concept for males, females, respondents at universities, community colleges, and continuing-education institutions.

For all these groups, except for the continuing-education group, the academic self-concept had the highest positive weight in separating the inadequate and adequate readers.

The second highest weight for each group in the order of importance were: for the male readers, decreasing physical selfconcept; for the female readers, decreasing personal self-concept and increasing moral-ethical self-concept; for the university respondents, decreasing personal self-concept; for community college respondents increasing social self-concept. For the continuing-education respondents, the increasing moral-ethical self-concept was the highest, followed by decreasing physical self-concept and increasing academic self-concept.

The social self-concept seemed to exert the least weight except for the community-college respondents. In this group social self-concept was the second in rank order of importance. 
Subcomponents. Table 24 presents the discriminant function analysis of the subcomponents of self-concept for inadequate and adequate male readers. For the test of significance of this discriminant function, chi-square is 40.68 with 16 degrees of freedom and a probability of .0006 . This discriminant function significantly separates the inadequate from the adequate readers.

This discriminant function is denoted, in descending order of importance of the subcomponents, by increasing academic self-concept, decreasing physical-behavior self-concept, decreasing social-selfsatisfaction self-concept, and increasing family-identity self-concept. On this function, the mean for inadequate readers is 2.62 and for adequate readers is 3.40 .

Table 25 presents the dicriminant function analysis of the subcomponents of self-concept for inadequate and adequate female readers. For the test of significance of this discriminant function, chi-square is 60.82 with 16 degrees of freedom and a probability of less than .0005 . The discriminant function significantly separates the inadequate and adequate readers.

This discriminant function is denoted, in descending order of importance of the subcomponents, by increasing academic selfconcept, increasing social-self-satisfaction self-concept, and decreasing personal-self-satisfaction self-concept. For this function, the mean for inadequate readers is 4.96 and for adequate readers 5.89 . Table 26. presents the discriminant function analysis of the subcomponents of self-concept for inadequate and adequate readers at the universities. For the test of significance of this discriminant function, the chi-square is 60.25 with 16 degrees of freedom and a 
TABLE 24

\section{DISCRIMINANT FUNCTION ANALYSIS OF THE \\ SUBCOMPONENTS OF SELF-CONCEPT FOR \\ INADEQUATE AND ADEQUATE \\ MALE READERS}

Self-Concept

Subcomponent

Physical-identity

Moral-ethical-

identity

Personal-identity

Family-identity

Social-identity

Physical-selfsatisfaction

Moral-ethicalself-satisfaction

Personal-selfsatisfaction

Family-selfsatisfaction

Social-selfsatisfaction

Physical-behavior

Moral-ethicalbehavior

Personal-behavior

Family-behavior

Social-behavior

Academic
Standard

Weight

$$
-.218
$$

7

$-.008$

15

.034

13

.412

$4 *$

.001

16

.107

10

.321

5

$-.121$

9

.026

14

$-.458$

$3 *$

$-.463$

$2 *$

.221

6

$-.069$

12

.072

11

.144

8

.688

* The relative weight values considered are at least $50 \%$ of the highest weight. 
TABLE 25

DISCRIMINANT FUNCTION ANALYSIS OF THE SUBCOMPONENTS OF SELF-CONCEPT FOR INADEQUATE AND ADEQUATE FEMALE READERS

\begin{tabular}{|c|c|c|}
\hline $\begin{array}{l}\text { Self-Concept } \\
\text { Subcomponent }\end{array}$ & $\begin{array}{l}\text { Standard } \\
\text { Weight }\end{array}$ & Rank \\
\hline Physical-identity & .043 & 16 \\
\hline $\begin{array}{l}\text { Moral-ethical- } \\
\text { identity }\end{array}$ & .061 & 13 \\
\hline Personal-identity & .052 & 14 \\
\hline Family-identity & .184 & 9 \\
\hline Social-identity & -.303 & 5 \\
\hline $\begin{array}{l}\text { Physical-self- } \\
\text { satisfaction }\end{array}$ & -.119 & 11 \\
\hline $\begin{array}{l}\text { Moral-ethical- } \\
\text { self-satisfaction }\end{array}$ & .263 & 7 \\
\hline $\begin{array}{l}\text { Personal-self- } \\
\text { satisfaction }\end{array}$ & -.389 & $3 *$ \\
\hline $\begin{array}{l}\text { Family-self- } \\
\text { satisfaction }\end{array}$ & -.081 & 12 \\
\hline $\begin{array}{l}\text { Social-self- } \\
\text { satisfaction }\end{array}$ & .404 & $2 *$ \\
\hline Physical-behavior & -.320 & 4 \\
\hline $\begin{array}{l}\text { Moral-ethical- } \\
\text { behavior }\end{array}$ & .046 & 15 \\
\hline Personal-behavior & -.174 & 10 \\
\hline Family-behavior & .199 & 8 \\
\hline Social-behavior & .268 & 6 \\
\hline Academic & .724 & $1 *$ \\
\hline
\end{tabular}

* The relative weight values considered are at least $50 \%$ of the highest weight. 
TABLE 26

DISCRIMINANT FUNCTION ANALYSIS OF THE SUBCOMPONENTS OF SELF-CONCEPT FOR

INADEQUATE AND ADEQUATE READERS AT THE UNIVERSITIES

\begin{tabular}{|c|c|c|}
\hline $\begin{array}{l}\text { Self-Concept } \\
\text { Subcomponent }\end{array}$ & $\begin{array}{l}\text { Standard } \\
\text { Weight }\end{array}$ & Rank \\
\hline Physical-identity & -.037 & 15 \\
\hline $\begin{array}{l}\text { Moral-ethical- } \\
\text { Identity }\end{array}$ & -.160 & 8 \\
\hline Personal-identity & .086 & 13 \\
\hline Family-identity & -.063 & 14 \\
\hline Social-identity & -.158 & 9 \\
\hline $\begin{array}{l}\text { Physical-self- } \\
\text { satisfaction }\end{array}$ & -.036 & 16 \\
\hline $\begin{array}{l}\text { Moral-ethical- } \\
\text { self-satisfaction }\end{array}$ & .330 & 5 \\
\hline $\begin{array}{l}\text { Personal-self- } \\
\text { satisfaction }\end{array}$ & -.526 & $2 *$ \\
\hline $\begin{array}{l}\text { Family-self- } \\
\text { satisfaction }\end{array}$ & .372 & 4 \\
\hline $\begin{array}{l}\text { Social-self- } \\
\text { behavior }\end{array}$ & -.124 & 11 \\
\hline Physical-behavior & -.377 & 3 \\
\hline $\begin{array}{l}\text { Moral-ethical- } \\
\text { behavior }\end{array}$ & .118 & 12 \\
\hline Personal-behavior & -.204 & 7 \\
\hline Family-behavior & .142 & 10 \\
\hline Social-behavior & .324 & 6 \\
\hline Academic & .836 & $1 *$ \\
\hline
\end{tabular}

* The relative weight values considered are at least $50 \%$ of the highest weight. 
probability of less than .0005 . This discriminant function signifIcantly separates the inadequate from the adequate readers.

This discriminant function is denoted in descending order of importance of the subcomponents, by increasing academic selfconcept and decreasing personal-self-satisfaction self-concept. For this discriminant function the mean for inadequate readers is 1.70 and for adequate readers is 2.65 .

Table 27 presents the discriminant function analysis of the subcomponents of self-concept for inadequate and adequate readers at community colleges. For the test of significance of this discriminant function, chi-square is 30.29 with 16 degrees of freedom and a probability of .00166 . This discriminant function significantly separates the inadequate from adequate readers.

This discriminant function is denoted, in descending order of importance of the subcomponents, by decreasing physicalidentity self-concept, increasing academic self-concept, increasing moral-ethical-self-satisfaction self-concept, decreasing family-selfsatisfaction, and increasing family-identity. For this discriminant function, the mean for inadequate readers is 5.29 and for adequate readers is 6.18 .

Table 28 presents the discriminant function analysis of the subcomponents of self-concepts of inadequate and adequate readers at the continuing-education institutions. For the test of significance of this discriminant function, chi-square is 57.50 with 16 degrees of freedom and a probability of less than .0005 . This discriminant function significantly separates inadequate from adequate readers. This discriminant function is denoted, in descending order 
TABLE 27

DISCRIMINANT FUNCTION ANALYSIS OF THE SUBCOMPONENTS OF SELF-CONCEPT FOR INADEQUATE AND ADEQUATE READERS AT COMMUNITY COLLEGES

\begin{tabular}{|c|c|c|}
\hline $\begin{array}{l}\text { Self-Concept } \\
\text { Subcomponent }\end{array}$ & $\begin{array}{l}\text { Standard } \\
\text { Weight }\end{array}$ & Rank \\
\hline Physical-identity & -.653 & $1 *$ \\
\hline $\begin{array}{l}\text { Moral-ethical- } \\
\text { identity }\end{array}$ & .086 & 11 \\
\hline Persona1-identity & .046 & 14 \\
\hline Family-identity & .431 & $5 *$ \\
\hline Social-identity & .136 & 7 \\
\hline $\begin{array}{l}\text { Physical-self- } \\
\text { satisfaction }\end{array}$ & .053 & 12 \\
\hline $\begin{array}{l}\text { Moral-ethical- } \\
\text { self-satisfaction }\end{array}$ & .577 & $3 *$ \\
\hline $\begin{array}{l}\text { Personal-self- } \\
\text { satisfaction }\end{array}$ & -.045 & 15 \\
\hline $\begin{array}{l}\text { Family-self- } \\
\text { satisfaction }\end{array}$ & -.528 & $4 *$ \\
\hline $\begin{array}{l}\text { Social-self- } \\
\text { satisfaction }\end{array}$ & -.102 & 9 \\
\hline Physical-behavior & .091 & 10 \\
\hline $\begin{array}{l}\text { Moral-ethical- } \\
\text { behavior }\end{array}$ & -.107 & 8 \\
\hline Personal-behavior & .011 & 16 \\
\hline Family-behavior & .050 & 13 \\
\hline Social-behavior & .246 & 6 \\
\hline Academic & .624 & $2 *$ \\
\hline
\end{tabular}

* The relative weight values considered are at least $50 \%$ of the highest weight. 
TABLE 28

DISCRIMINANT FUNCTION ANALYSIS OF THE SUBCOMPONENTS OF SELF-CONCEPT FOR INADEQUATE AND ADEQUATE READERS AT CONTINUING-EDUCATION INSTITUTIONS

\begin{tabular}{|c|c|c|}
\hline $\begin{array}{l}\text { Self-Concept } \\
\text { Subcomponent: }\end{array}$ & $\begin{array}{l}\text { Standard } \\
\text { Weight }\end{array}$ & Rank \\
\hline Physical-identity & .192 & 9 \\
\hline $\begin{array}{l}\text { Moral-ethical- } \\
\text { identity }\end{array}$ & .540 & $1 *$ \\
\hline Personal-identity & -.173 & 11 \\
\hline Family-identity & .404 & $3 *$ \\
\hline Social-identity & -.100 & 14 \\
\hline $\begin{array}{l}\text { Physical-self- } \\
\text { satisfaction }\end{array}$ & -.188 & 10 \\
\hline $\begin{array}{l}\text { Moral-ethical- } \\
\text { self-satisfaction }\end{array}$ & .090 & 15 \\
\hline $\begin{array}{l}\text { Personal-self- } \\
\text { satisfaction }\end{array}$ & .248 & 5 \\
\hline $\begin{array}{l}\text { Family-self- } \\
\text { satisfaction }\end{array}$ & -.240 & 6 \\
\hline $\begin{array}{l}\text { Social-self- } \\
\text { satisfaction }\end{array}$ & -.117 & 13 \\
\hline Physical-behavior & -.470 & $2 *$ \\
\hline $\begin{array}{l}\text { Moral-ethical- } \\
\text { behavior }\end{array}$ & .212 & 7 \\
\hline Personal-behavior & .120 & 12 \\
\hline Family-behavior & .030 & 16 \\
\hline Social-behavior & .208 & 8 \\
\hline Academic & .314 & $4 *$ \\
\hline
\end{tabular}

* The relative weight values considered are at least $50 \%$ of the highest weight. 
of importance of the subcomponents, by an increasing moral-ethicalIdentity self-concept, decreasing physical-behavior self-concept, increasing family-identity self-concept, increasing academic selfconcept. For this discriminant function the mean for inadequate readers is 5.88 and for adequate readers is 7.16 .

The discriminant function on the subcomponents of self-concept for Inadequate and adequate readers on five categories of readers is presented in tables 24 through 28 .

The analysis of the data shows that there is a linear combination of the sixteen subcomponents of self-concept to significantly separate the inadequate from adequate readers in each of the five categories: male, female, universities, community colleges, and continuing-education institutions. The academic self-concept exerts the greatest weight of the sixteen self-components for the male, female, and university respondents. Among the community college respondents the greatest weight was decreasing physical-identity selfconcept, while among the continuing-education respondents the greatest weight was increasing moral-ethical-identity self-concept in separating inadequate from adequate readers. 


\section{CHAPTER V}

\section{SUMMARY, CONCLUSIONS, AND RECOMMENDATIONS}

This chapter presents the summary, conclusions, and recomendations for the study. The rationale of the study stemed from the concept that inadequate readers who are enrolled in higher-education institutions frequently display a low self-concept which may be associated with poor academic skills.

\section{Summary}

The summary of this study consists of four sections, namely: (1) the purpose, (2) overview of related studies, (3) population, delimitation, and instrumentation, and (4) findings.

\section{Purpose}

The purpose of this study was to analyze the components of the self-concept of inadequate and adequate adult readers, to ascertain what patterns of self-concept emerge in various groups. The corollary purposes of the study were to compare the self-concept of adequate- and inadequate-reader groups to the self-concept of the general population and to determine the relative weight of importance of the various components, dimensions, and subcomponents in distinguishing inadequate adult readers from adequate adult readers according to sex and type of Institution. Nine hypotheses were formulated and projected for the study. 
Overview of related studies

The review of 1 terature of this study was divided into five sections. The first covered the historical background and perspectives from Aristotle's historical record De anima (On the Soul) to the modern interpreters of the self such as James, Mead, Cooley, and Freud.

The second section dealt with the self-concept and its relationship to academic performance. Most of the literature cited involved research with children. Self-concept is a type of concomitant learning, as perceived through the eyes of significant others such as family members, teachers, and peers. Researchers concluded that self-concept of academic ability is associated with academic achievement at each grade level. High self-esteem and high reading ability reinforce each other as do low self-esteem and low reading ability.

The third section dealt with the self-concept of adults. The influence of the relationship of significant others reverberates throughout the adult life-span. Generally there is a studied effort of each individual to preserve consistency of the self-concept; self resists modification. A low self-concept is generated by frustrated efforts to attain goals or meet aspirations. Individuals who possess necessary resiliency in coping with personal needs, who accept themselves, and who accept others display positive self-concepts. Those who espouse a Biblical approach to self-concept state that a Christian need not negate his accomplishments but, by the grace of God, accept himself and express his self-worth. A directional shift takes place. 
Instead of seeking approval of others, the individual now seeks to please God.

The adult self-concept and reading ability were reviewed in the fourth section. Six college-level studies cited indicated that good readers possessed a high degree of personality traits conducive to good adjustment to college. In addition to the acquisition of reading skills, remedial college students benefit from personal counseling.

Evidence of the burgeoning interest in research in selfconcept is demonstrated by the numerous self-concept instruments constructed for use in clinical and educational settings. The fifth section reviews the self-concept instruments. The Likert-type positive and negative scales, adjective or sentence Q-sort tests and differential scales, and open-ended questionnaires are most frequently used.

Population, delimitations, and instrumentation

The subjects for the study were drawn from the universities, community colleges, and continuing-education institutions of southwestern Michigan during the school year 1976-1977. The inadequate readers were subjects enrolled in reading improvement and literacy classes in the institutions. About the same number of adequate readers were chosen randomly through the student roster or classes of students chosen as volunteer groups from the same institutions. Respondents for whom English was a second language, respondents who deliberately made an attempt to give a favorable picture of themselves, 
and respondents who filled in the OpScan sheet incorrectly were excluded from the study.

The total number of subjects was 569, of which 283 were adequate readers and 286 . inadequate readers. Of the total sample, 267 came from universities, 152 from community colleges, and 141 from continuing-education institutions. The data on nine subjects could not be processed under the category, type of educational institution, because of inaccurate marking, but these subjects were used for other categorical groups, such as age groups.

To separate the adult students into adequate and inadequate readers, the Nelson-Denny Reading Test, the ACT scores, and the Reading Progress Scale were used.

The evaluating instrument for the study, the Self-Questionnaire, consisted of biographical data, all items from the Tennessee Self Concept Scale (TSCS), and the Michigan State General Self-Concept of Ability Scale (SCA).

\section{Findings and discussion}

This section presents the findings regarding the nine null hypotheses. Each hypothesis was accepted or rejected according to the test of significance. To test the hypotheses alpha was set at the .051 leve1.

Hypothesis 1 . There is no significant difference between the total self-concept of inadequate adult readers and the normal population as described in the Tennessee Self Concept Scale (TSCS) norms over the whole sample, and as categorized according to sex, race, age, and educational institution. 
On the basis of the data on the whole sample of inadequate adult readers, hypothesis 1 was rejected. It can be concluded that there is a significant difference between the total self-concept of inadequate readers and the normal population. The sample of inadequate readers scored significantly lower than the normal population. This finding is in accordance with other research reviewed in the Iiterature (Brookover et a1, 1965; Gergen, 1971; Quandt, 1972).

The first hypothesis further dealt with reader categories divided into ten groups. On the basis of the data concerning nine of these groups, the hypothesis was rejected. Therefore, there is a significant difference between the following groups of inadequate readers and the normal population: male, female, white, the undertwenty age group, the twenty-one-to-thirty age group, and readers at universities, community colleges, and continuing-education institutions. All these groups scored significantly lower than the norm. When testing for significance on data for black readers, the hypothesis was accepted. This indicates that there is no significant difference between the self-concept of black inadequate readers and the normal population. Of all the groups of inadequate readers tested, the black group was the only one whose self-concept mean was not significantly lower than the norm mean. It appears that recent changes in the self-image among black children (McMillan, 1976) is also taking place on the young-adult level. Perhaps being enrolled In a higher-learning educational institution may raise a black adult's self-concept regardless of his reading ability.

Hypothesis 2. There is no significant difference between the total self-concept of adequate adult readers and the normal population as described in the TSCS norm:over 
the whole sample and as categorized according to sex, race, age, and educational institution.

On the basis of the data on the whole sample of adequate adult readers, hypothesis 2 was rejected. It can be concluded that there is a significant difference between the total self-concept of adequate readers and the normal population. The mean self-concept of adequate readers was significantly lower than that of the normal population. Other studies have not obtained the same results (Purkey, 1970).

Data analysis of the ten comparable groups of adequate readers. showed that for the following six the hypotheses were rejected: male, white, twenty-one-to-thirty age group, over-thirty age group, and readers at universities and community colleges.) Therefore, there is a significant difference between these groups and the normal population. Their self-concept was lower than that of the normal population. For each of the remaining four groups, the hypothesis was accepted. There is no significant difference between the self-concept of adequate readers of the following groups and the normal population: female, black, the under-twenty age group, and readers at continuingeducation institutions. It appears that these readers tend to belong to minority or commonly discriminated-against groups.

That some adequate reader groups should have significantly different from and lower self-concepts than the normal population comes as a surprise. From the literature revlewed (McCandless, 1967; Wylie, 1974) and from observation, it would be presumed that adequate readers would have a higher self-concept than the normal population. Factors other than reading ability obviously influenced this area. 
Hypothesis 3. There is no signficant difference between the centroid of the components for the inadequate readers and the centroid for the norm group.

The findings show that this hypothesis was not supported. Therefore, there is a significant difference between the centroid of the components of self-concept for inadequate readers and the centrold for the norm group. Inadequate readers show a consistently lower self-concept in each component, contributing to a lower selfconcept centroid than the normal population. According to research findings and observations this phenomenon is predictable.

Hypothesis 4 . There is no significant difference between the centroid of the components for the adequate readers and the centroid for the norm group.

The analysis of the data does not support hypothesis 4 . There is a significant difference between the centroid of the components of self-concept for adequate readers and the centroid for the norm group. The adequate readers of this sample achieved a mean score lower than the norm score on all components of concept except personal. Generally one would not expect that the self-concept component centroid of adequate readers would be significantly lower than the normal population. However, the college and university students, the majority population sample, seem to be more sensitive to the complexity of their self-concept. A general dissatisfaction with themselves when the ideal self is so distant to the real self (Black \& Thomas, 1955) maý account for some of the low self-appraisals.

Hypothesis 5. There is no significant difference between the centroid of the dimensions for the inadequate readers and the centroid for the norm group.

Hypothesis 5 was not supported by the analysis of the data, therefore it was rejected. The findings indicate that there is a 
significant difference between the centroid of dimensions of selfconcept for inadequate readers and the centroid for the norm group. Inadequate readers show a consistently lower self-concept in each dimension, contributing to a lower self-concept centroid than the normal population.

Since the same readers are tested on the same subcomponents which make up the components of hypothesis 3 , this result is not surprising. Low self-concept and low academic ability reinforce each other to lower the centroid of the inadequate readers.

Hypothesis 6 . There is no significant difference between the centroid of the dimensions for the adequate readers and the centroid for the norm group.

Regarding hypothesis 6 , the findings show that this hypothesis was not supported by the data. There is a significant difference between the centroid of the dimensions of self-concept for adequate readers and the centroid for the norm group. This sample of adequate readers achieved a mean score below the norm particularly on the identity and behavior dimensions.

Since the same group of readers is tested on the same subcomponents which make up the components of hypothesis 4 , the results are not suprising.

Hypothesis 7. There is no linear combination of the three dimensions of self-concept to significantly distinguish inadequate adult readers from adequate adult readers as categorized by sex and educational institution.

Hypothesis 7 was accepted on all categories of sex and educational institution except on the continuing-education group where it was rejected. There is no linear combination of the three dimensions to significantly separate inadequate and adequate readers when classified in the following groups: male, female, and respondents at 
universities and community colleges. However, there is a inear combination of the three dimensions which significantly separates the Inadequate and adequate readers in continuing-education institutions. The greatest welght in separating these two groups is the identity dimension.

The adequate readers at continuing-education institutions tend to have a higher identity self-concept than the inadequate readers. It has been observed that continuing-education students in this sample tend to be either in remedial or life-enrichment programs. Possibly the more professional students demonstrated significantly higher identity than did the remedial students.

Hypothesis 8 . There is no linear combination of the six components of self-concept to significantly distinguish inadequate adult readers from adequate adult readers as categorized by sex and educational institution.

Hypothesis 8 was rejected on all categories of sex and educational institution. There is a linear combination of the six components of self-concept to significantly separate inadequate and adequate readers in all five categories: male, female, and respondents at universities, community colleges, and continuing-education institutions.

For males, the adequate readers tended to have more positive academic self-concept, more negative physical self-concept, more positive family and moral-ethical self-concepts than the inadequate readers. For females, the adequate readers tended to have more positive academic self-concept, more negative personal self-concept, and more positive moral-ethical self-concept than the inadequate readers. The inadequate and adequate reader groups for both males 
and females were separated significantly by more positive academic and moral-ethical self-concepts.

For respondents at the universities, the adequate readers tended to have more positive academic self-concept and more negative personal self-concept than the inadequate readers. For respondents at community colleges, the adequate readers tended to have more positive academic self-concept and social self-concept and more negative physical self-concept than the inadequate readers. For respondents at continuing-education institutions the adequate readers tended to have more positive moral-ethical self-concept, more negative physical selfconcept, and more positive academic self-concept than the inadequate readers.

In examining the relative weights that separate inadequate and adequate readers at the educational institutions, positive academic self-concept is the greatest weight that best separates the two groups at universities and community colleges, but it ranks third in weight in separating readers at continuing-education institutions. More component variables contributed to separating inadequate and adequate readers among respondents from community colleges and continuing-education institutions than that of the university respondents. This finding may be related to the greater diversity among community college and continuing-education students. Among university students, academic self-concept differentiated best between adequate and inadequate readers. This may indicate that the high academic self-concept of adequate readers stands in great contrast to the low academic self-concept of inadequate readers, which may be expected. 
Hypothesis 9. There is no linear combination of the sixteen subcomponents of self-concept to significantly distinguish inadequate adult readers from adequate adult readers as categorized by sex and educational institution.

Hypothesis 9 was rejected on all categories of sex and educational institution. Therefore, there is a linear combination of the slxteen subcomponents of self-concept to significantly separate Inadequate and adequate readers in all five categories: male, female, and respondents at universities, community colleges, and continuingeducation institutions.

For males the adequate readers tended to have more positive academic, more negative physical-behavior and social-selfsatisfaction, and more positive family-identity self-concepts than the inadequate readers. For females, the adequate readers tended to have self-concepts with more positive academic and social-selfsatisfaction, and more negative personal-self-satisfaction subcomponents to separate them from inadequate readers. In an academic setting, there seems to be a strong tendency to evaluate oneself according to one's academic ability. This may be related to the positive academic self-concept subcomponent among both males and females.

For respondents at the universities, adequate readers tended to have self-concepts with more positive academic self-concept and more negative personal-self-satisfaction subcomponents which separated them from the inadequate readers. While students from other educational institutions had a greater number of subcomponents differentiating them, university students had only two, the academic selfconcept and personal-self-satisfaction. Among both components and subcomponents which have the greatest relative weight separating 
inadequate and adequate readers in unfversities, the directions were Identical and the relative weights were similar.

For respondents at community colleges, the adequate readers tended to have self-concepts with more negative physical-identity, more positive academic self-concept and moral-ethical-self-satisfaction, more negative family-self-satisfaction, and a more positive family-identity which separate them from the inadequate readers.

For respondents at continuing-education institutions, the adequate readers tended to have a self-concept with more positive moral-ethical-identity, more negative physical-behavior, more posi-. tive family identity, and academic self-concept which separate them from inadequate readers.

Subjects from community colleges and continuing-education institutions seem to have many different weights pulling in different directions when separating the groups. These groups seem to have a variety of objectives and interests with diverse social life-styles. Their self-concepts seem to have been derived from widely differing sources when compared to university respondents.

The sample populations were all enrolled in school institutions. Thus it seems plausible to conclude that academic ability would exert a studied influence on the self-concept of all student groups.

\section{Conclusions}

From the foregoing findings the following conclusions emerged:

1. Inadequate adult readers in this study have a lower selfconcept than the normal population. 
2. Adequate adult readers in this study also have a lower self-concept than the normal population.

3. When inadequate readers were categorized in groups according to sex, race, age groups, and educational institution, all categories except black inadequate readers show significantly lower self-concepts than the normal population.

4. When adequate readers were categorized in groups according to sex, race, age groups, and educational institution some categories were lower and significantly different from but others were similar to the normal population.

5. The centroid of the self-concept dimensions of inadequate and adequate readers were significantly different from the centroid of the normal population.

6. The centroid of the self-concept components of inadequate and adequate readers were significantly different from the centroid of the normal population.

7. On a linear combination of the components of self-concept the positive academic self-concept exerts the greatest weight that significantly separates inadequate and adequate adult readers:

8. On a linear combination of the subcomponents of selfconcept, the positive academic self-concept also exerts the greatest weight that significantly separates inadequate and adequate adult readers.

9. Fewer variables separate inadequate and adequate university-reading students than community college and continuingeducation students. 


\section{Recommendations}

As this research progressed, other questions were raised which were not part of the present study. Therefore the following recommendations for further investigation are suggested:

1. A similar study with a stratified random sample on a state-wide basis should be undertaken. When replicated this study should include academic and/or reading self-concept items for respondents at academic institutions. Individuals not attending any academic institution should also be sampled.

2. Experimental studies should be undertaken to ascertain changes of self-concept components such as physical self-concept and social self-concept among adult students in remedial classes. Students who have low self-concepts because of deficiencies in skills such as reading, mathematics, or social skills could be pretested and posttested in the deficient area to measure what skill. gains and concomitant self-concept gains are apparent.

3. Through adjective or sentence Q-sort instruments conste1lations or clusters of traits should be identified in low self-concept and high self-concept groups in specific areas such as sports, occupations, and scholastic achievement.

4. In regards to inadequate readers possessing low selfconcepts, further study should be undertaken to determine the reasons for or the roots of low self-esteem. The study should determine to what extent self-esteem is a by-product of or a contributor to school success.

5. A large-scale investigation should be conducted on the self-concept of black adult students. This study should control for 
location, socio-economic status, intelligence, and school achievement. A comparable number of other races should act as a control group to determine the patterns, changes, and differences in the total selfconcept and self-concept dimensions.

6. The academic self-concept seems to have the greatest weight in significantly separating inadequate and adequate adult readers. It is recommended that the study be duplicated using only the academic self-concept variable with an adult population as Brookover and his associates (1965) have done with children.

7. The academic self-concept in this study overshadows the other components of self-concept. It is recommended that a study be duplicated omitting the academic self-concept variable in order to observe the relative weights of the other five components in distinguishing the two groups.

8. There is an imperative need for more sensitive and refined self-concept instruments which would control for variables such as Intelligence, culture, economic status, work environment, study environment, and levels of aspirations. 
APPENDIX A

COVERING LETTER 
Andrews University Berrien Springs, Michigan 49104 (616) 471-7771

April 8, 1977

\section{Dear Student:}

I am currently enrolled as a doctoral student in Educational Psychology and Counseling at Andrews University and propose to develop a dissertation on "Self-Concept Patterns of Adult Reading Students."

The main hypothesis of the study deals with inadequate readers. However, to develop this thesis, I will need specific information on adequate readers. Your name has been chosen from the student roster, to assist in this also, as one of the adequate readers. As a reward for your participation, you will find out your score and reading level as compared to the national norms for college students.

The procedures are as follows: Come to Lamson Chapel on Thursday, April 14, or Meier Hall Gold Room April 21, right after evening worship. You will take a short form. Nelson-Denny Reading Test which takes about 17 minutes. You then will fill out an attitude questionnaire on how you feel about yourself. The total time should take 30 to 40 minutes.

Responses will be kept confidential -- your name does not appear on the data sheet. Only group findings will be presented.

I appreciate the time and effort that you will expend, and I am sincerely grateful for your cooperation in supporting me in this endeavor. I really believe that the findings will be beneficial not only to the students at Andrews University but also to other undergraduate schools.

Thank you for participating.

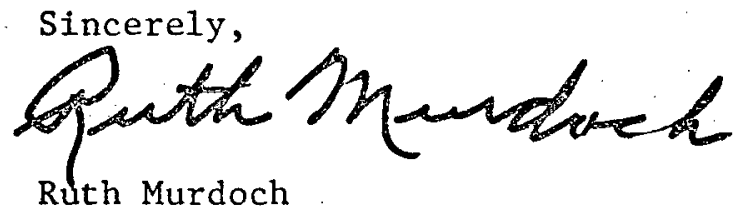

Professor of Education

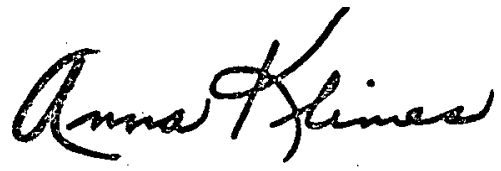

Anna Klimes

Reading Center

bh 



\section{SELF QUESTIONNAIRE}

\section{D1rections:}

Don't skip any items. Answer each one. Use a soft lead pencll. Pens won't work. If you change an answer, you must erase the old answer completely and enter the new one.

*1. Sex

1. Male

2. Female

2. Age Group

1. Under 20 years

2. 21 to 30 years

3. 31 to 40 years

4. Over 40 years

3. First Language

1. English

(Mother tongue)

2. Spanish

3. Other

4. School

1. Andrews University

2. Western Michigan Liviversity

3. Lake Michigan College

4. Southwestern Michigan College

5. Continuing Education Class

5. Grade in School

1. High school or below

2. Freshman in college

3. Sophomore in college

4. Junior, Senior in college

5. Graduate

6. Race
1. Black
2. White
3. Other

7. Religion

1. Seventh-day Adventist

2. Other

†8. How do you rate yourself in school abtlity compared with your close friends?

1. I an the best

2. I an above average

3. I am average

4. I am below average

5. I am the poorest

*Demographic Data, 1-7.

†SCA Scales, 8-15.
9. How do you rate yourself in school ability compared with those in your class at school?

1. I am among the best

2. I am above average

3. I am average

4. I am below average

5. I am among the poorest

10. Where do you think you would rank in your class in high school?

1. Among the best

2. Above average

3. Average

4. Below average

5. Among the poorest

11. Do you think you have the ability to complete college?

1. Yes, definitely

2. Yes, probably

3. Not sure either way

4. Probably not

5. No

12. Where do you think you would rank in your class in college?

1. Among the best

2. Above average

3. Ave rage

4. Below average

5. Among the poorest

13. In order to become a doctor, lawyer, or university professor, work beyond your four years of college is necessary. How likely do you think it is that you could complete such advanced work?

1. Very likely

2. Somewhat likely

3. Not sure either way

4. Unlikely

5. Most unlikely

14. Forget for a moment how others grade your work. In your own opinion how good do you think your work is?

1. My work is excellent

2. My work is good

3. My work is average

4. My work is below average

5. My work is much below average

15. What kind of grades do you think you are capable of getting?

1. Mostly A's

2. Mostly B's

3. Mostly C's

4. Mostly D's

5. Mostly E's 


\section{THE TENNESSEE SELF CONCEPT SCALE}

Directions: The statements in this iriventory are to help you describe yourself as you see yourself. Please answer them as if you were describing yourself to yourself. Read each item carefully; then select one of the five responses below and fill in the answer space on the separate answer sheet.

$\begin{array}{ccccc}\text { Completely } & \text { Mostly } & \text { Partly False } & \text { Mostly } & \text { Completely } \\ \text { False } & \text { False } & \text { Partly True } & \text { True } & \text { True }\end{array}$

$\begin{array}{lllll}1 & 2 & 3 & 4 & 5\end{array}$

16. I have a healthy body ................. 16

17. I am an attractive person.................. 17

18. I consider myself a sloppy person ............... 18

19. I am a decent sort of person. ............... 19

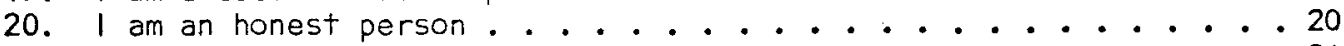

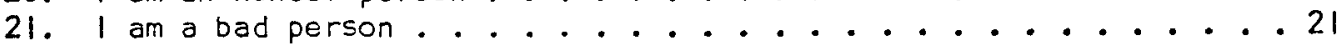

22. I am a cheerful person.................. 22

23. I am a calm and easy going person ............. 23

24. I am a nobody . . . . . . . . . . . . . . . . 24

25. I have a family that would always help me in any kind of trouble. . 25

26. I am a member of a happy family ..............26 26

27. My friends have no confidence in me ........... 27

28. I am a friendly person. . . . . . . . . . . 28

29. I am popular with men ................ 29

30. I am not interested in what other people do ......... 30

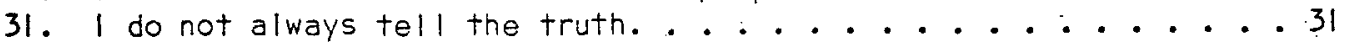

32. I get angry sometimes . . . . . . . . . . . . . . 32

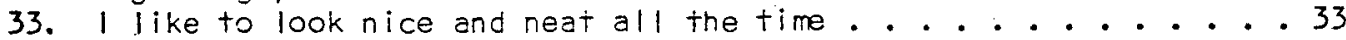

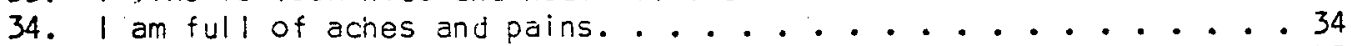

35. I am a sick person................. 35

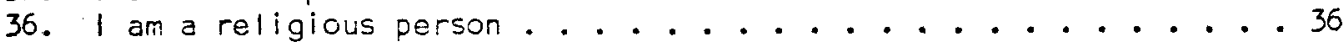

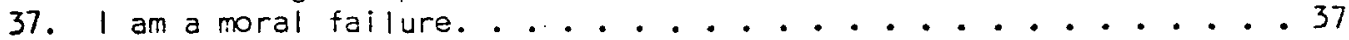

38. I am a morally weak person. . . . . . . . . . ..... 38

39. I have a lot of self-control. .............. 39

40. I am a hateful person................. . . 40

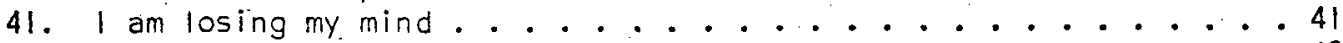

42. I am an important person to mv friends and family....... 42

43. I am not loved by my family ....................... 43

44. I feel that my family doesn't trust me. . . . . . . . . . 44 4

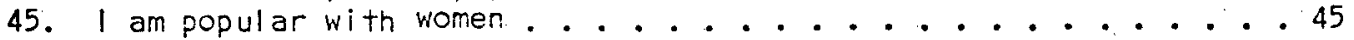

46. I am mad at the whole world ..................... 46

47. I am hard to be friendly with .............. 47

48. Once in a while 1 think of things too bad to talk about.....48

49. Sometimes when 1 am not feeling well, I am cross. ......... 49

50. I am neither too fat nor too thin............ 50

51. I like my looks just the way they are............ 51

52. I would like to change some parts of my body. . . . . . . . . . 52

53. I am satisfied with my moral behavior. . . . . . . . . 53

54. I am satisfied with my relationship to God. . . . . . . . . 54

55. I ought to go to church more. .............. 55

56. I am satisfied to be just what I am ........... 56

57. I am just as nice as 1 should be. .............. 57

58. I despise myself. . . . . . . . . . . . . . . 58

59. I am satisfied with my family relationships......... . . 59

60. I understand my family as well as I should. . ..........60 60

61. I should trust my family more ...............61

62. I am as sociable as 1 want to be..............62 
63. I try to please others, but 1 don't overdo if . . . . . . . 63

64. I am no good at all from a social standpoint. . . . . . . . . . 64

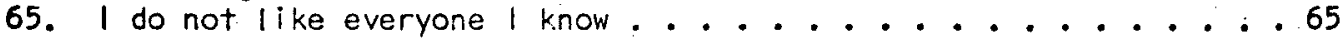

66. Once in a while, 1 laugh at a dirty joke. . . . . . . . . . . 66

67. I am neither too tall nor too short.............. 67

68. I don't feel as well as 1 should. . . . . . . . . . . . . 68

69. I should have more sex appeal.............. 69

70. I am as religious as 1 want to be.............. 70

71. I wish. I could be more trustworthy. . . ............ 71

72. I shouldn't tell so many lies............... 72

73. I am as smart as 1 want to be.................. 73

74. I am not the person I would like to be............. . . . 74

75. I wish I didn't.give up as easily as I do . . . . . . . . . . 75

76. I treat my parents as well as I should (Use past tense if parents are not living). . . . . . . . . . . . . . . . 76

77. I am too sensitive to things my family may say. . . . . . . . . . 77

78. I should love my family more.................... 78

79. I am satisfied with the way I treat other people. . . . . . . 79

80. I should be more polite to others . . . . . . . . . . . . 80

81. I ought to get along better with other people......... . 81

82. I gossip a little at times. . . . . . . . . . . . . 82

83. At times 1 feel like swearing. . . . . . . . . . . . . . 83

84. I take good care of myself physically .............. . 84

85. I try to be careful about my appearance . . . . . . . . . . 85

86. I often act like I am "all thumbs". . . . . . . . . . . . . . 86

87. I am true to my religion in my every day life.......... 87

88. I try to change when ! know $1^{\prime} \mathrm{m}$ doing things that are wrong . . . 88

89. I sometimes do very bad things. . . . . . . . . . . . . 89

90. I can always take care of myselt in any situation........ 90

91. I take the blame for things without getting mad..........91

92. I do things without thinking about them first. . . . . . . . . 92

93. I try to play fair with my friends and family . . . . . . . . . 93

94. I take a real interest in my family . . . . . . . . . . . . . 94

95. I give in to my parents (Use past tense if parents are not living). 95

96. I try to understand the other fellow's point of view. . . . . . . 96

97. I get along well with other people. . . . . . . . . . . 97

98. I do not forgive others easily. . . . . . . . . . . . . 98

99. I would rather win than lose in: a game. . . . . . . . . . . 99

100. I feel good most of the time................... 100

101. I do poorly in sports and games.................. . . . . . . 101

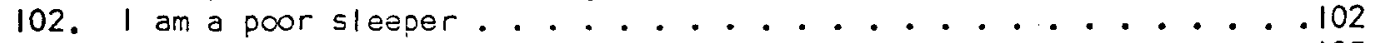

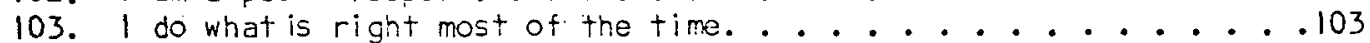

104. I sometimes use unfair means to get ahead............. 104

105. I have trouble doing the things that are right. ......... 105

106. I solve my problems quite easily. . . ............. 106

107. I change my mind a lot. ..................... . . . . . . . . . . . . . . .

108. I try to run away from my problems. . . . . . . ........ 108

109. I do my share of work at home................... 109

110. I quarrel with my family. ................... 110

111. I do not act like my family thinks I should ............. . III

112. I see gocd points in all the people I meet. . . . . . . . . . . 112

113. I do not feel at ease with other people..............113

114. I find it hard to talk with strangers . . . ............ . . . . . . 4

115. Once in a while I put off until tomorrow what 1 ought to do today .115 

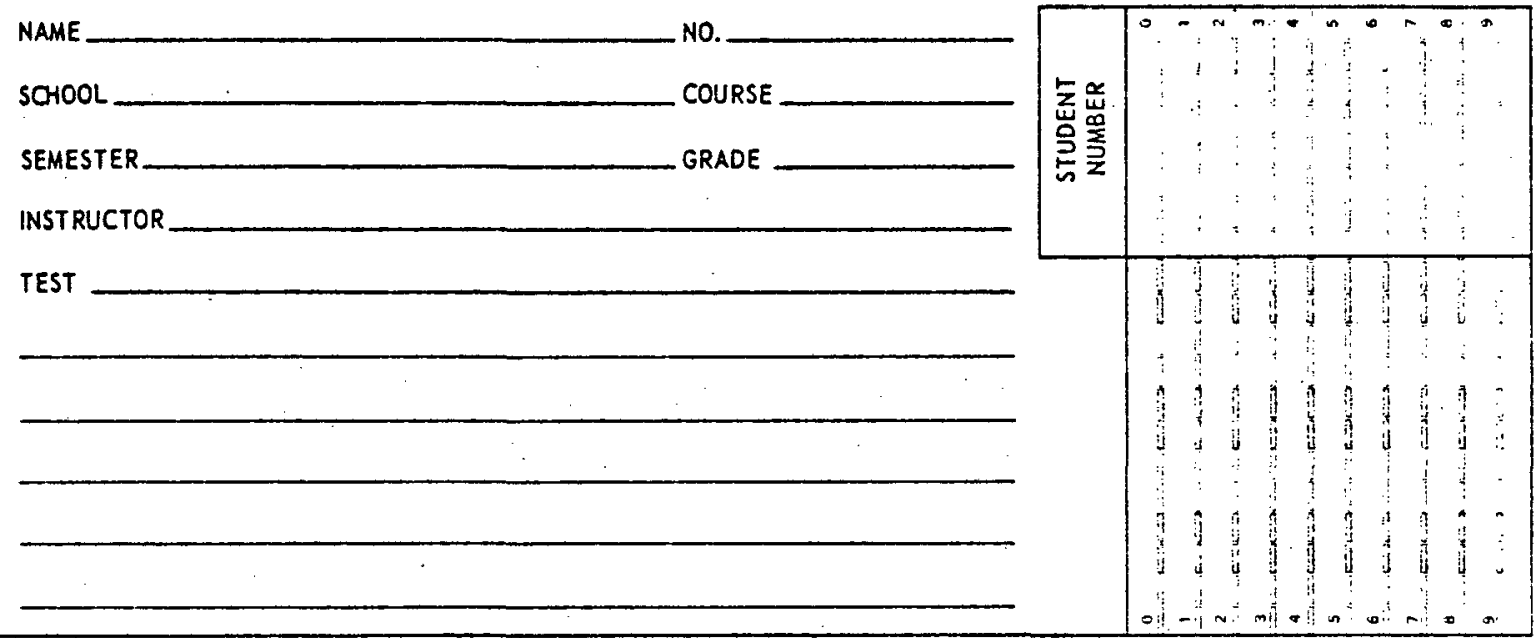

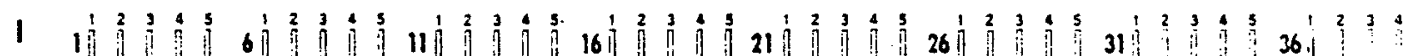
2 2) 3

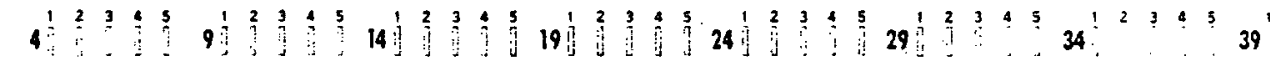

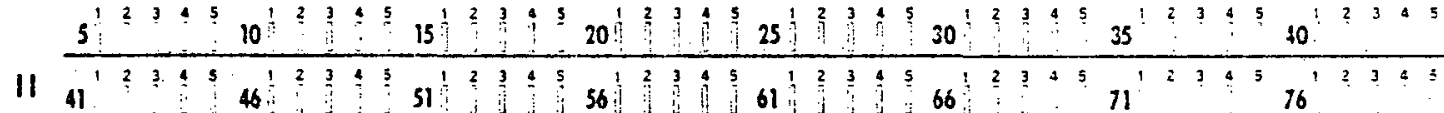

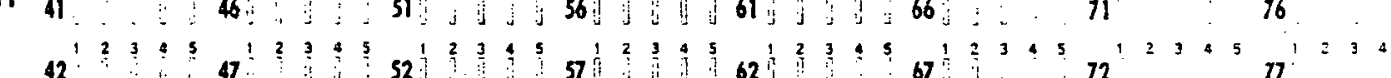

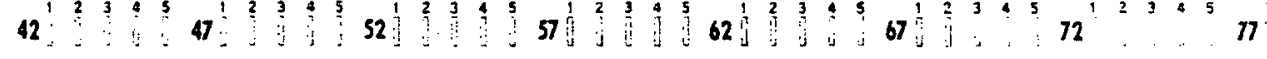

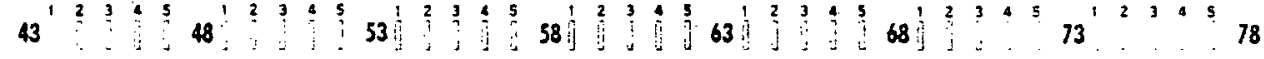

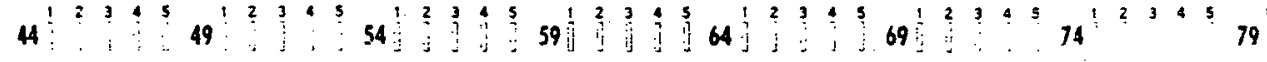

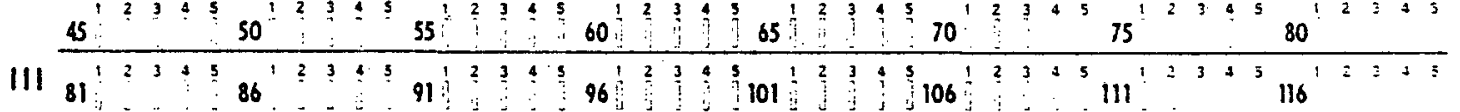

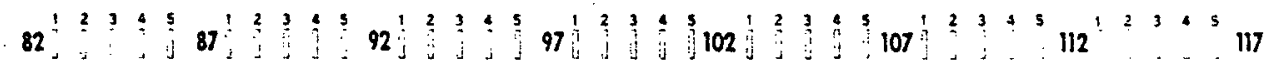

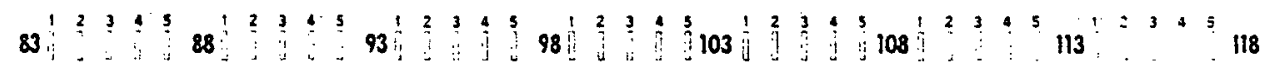

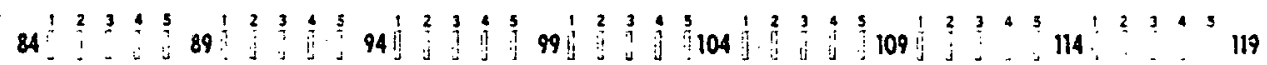

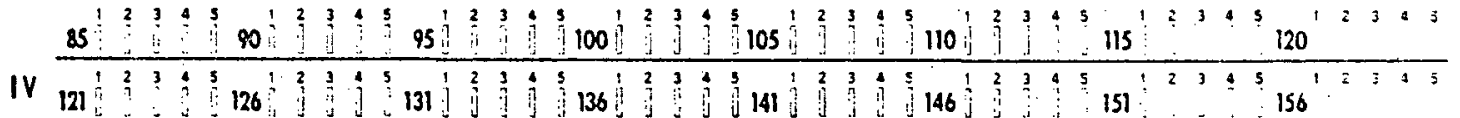

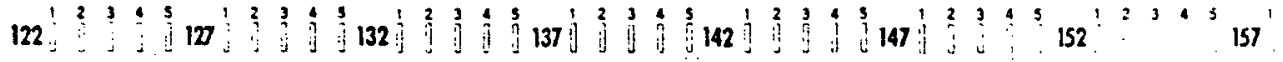

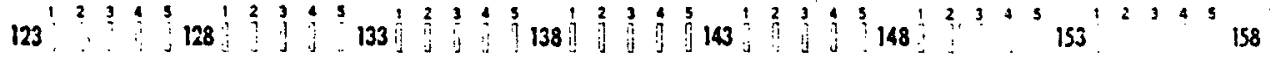

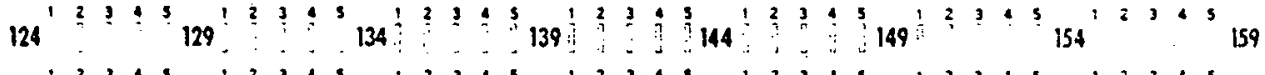

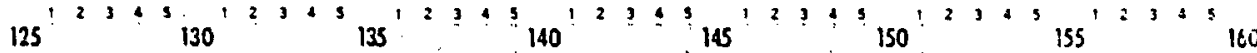
os rosu 
SELF QUESTIONNAIRE

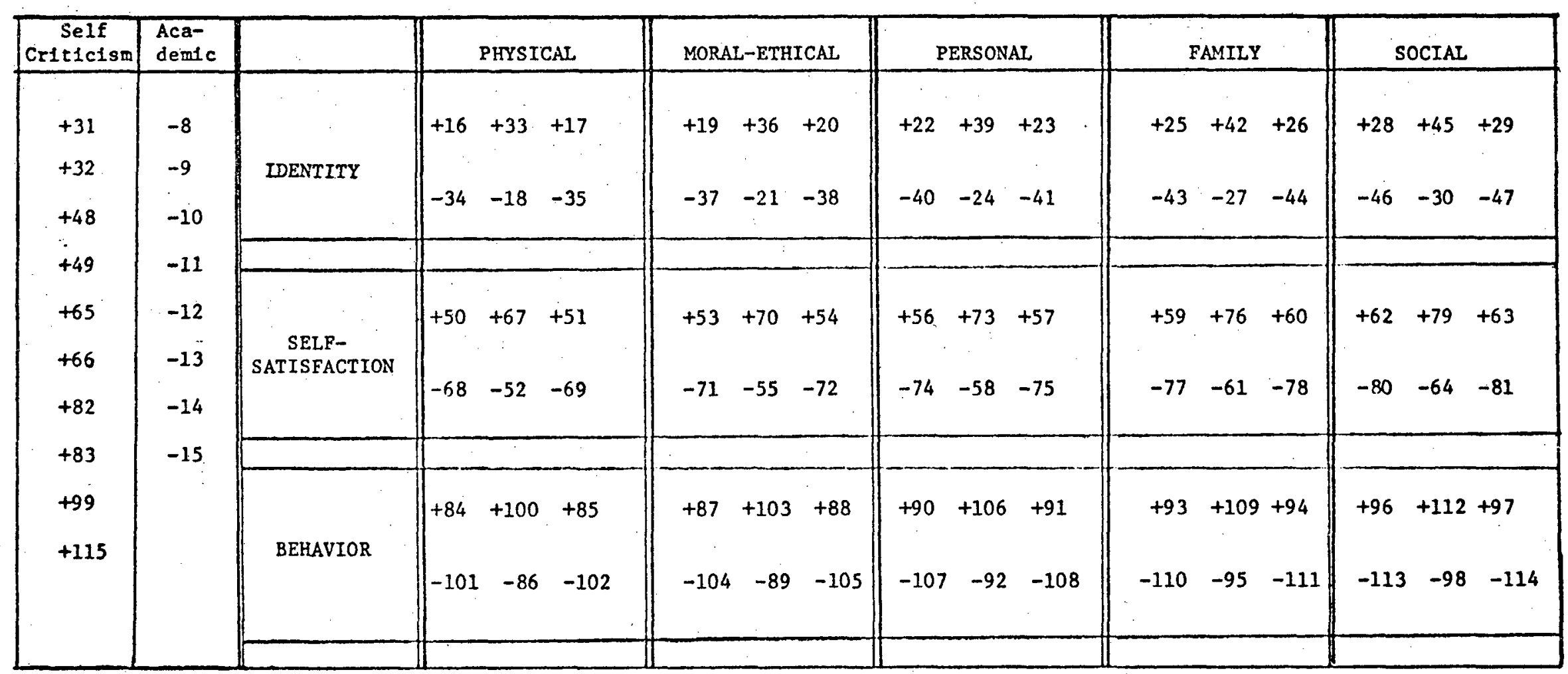


APPENDIX C

COPYRIGHT PERMISSION LETTERS 
102

MICHIGAN STATE UNIVERSIT'Y EAST LANSING • MICHIGAN 48823

DEPARTMENT OF URBAN AND METROPOLITAN STUDIES - COLLEGE OF URBAN DEVELOPMENT

October 7, 1976

Anna Klimes, Instructor

Andrews University

Reading Center

Berries Springs, MI 49104

Dear Ms. Klimes:

Your letter addressed to the Bureau of Educational Research has been referred to me. I am happy to give you permission to use the Self-Concept of Academic Ability Scale in your research. I would appreciate receiving a report of your research when it is completed.

Cordially yours,

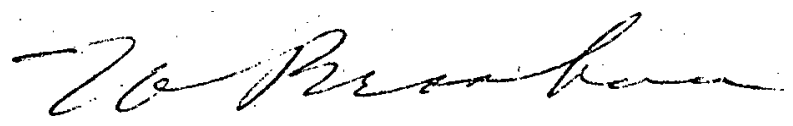

W.B. Brookover

Professor

WBB: ca 


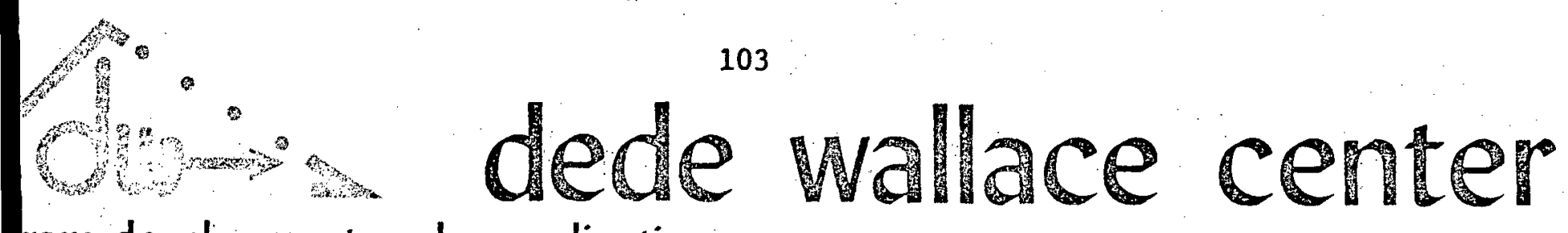
ram development and coordination · 700 craighead avenue · nashville, tennessee 37204 - phone 297-9506

October 15, 1976

Ms. Anna Klimes, Instructor

Reading Center

Andrews University

101 S. George

Berrien Springs, Mich. 49103

Deax Ms. Klimes:

In regard to your letter of $10 / 1 / 76$, your order for Monograph III, The Self Concept and Self-Actualization has been forwarded to the publisher:

Counselor Recordings and Tests

Box 6184 Acklen Station

Nashville, Tn. 37212

They will mail the book directly to you and bill you, so I am returning your check. The current price of the monographs is $\$ 3.25$ each.

If you are doing some kind of research with the TSCS, I would like to hear about it and receive a report of findings----preferably in the form of a copy of whatever you write or publish.

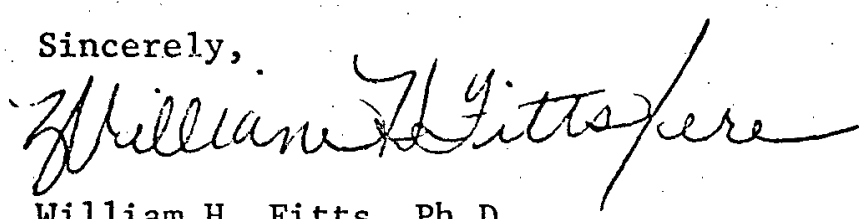

William H. Fitts, Ph.D.

Senior Psychologist

WHF/ere

enc. 
APPENDIX D

INSTRUCTION SHEETS FOR

ADMINISTRATORS OF INSTRUMENTS 


\section{DIRECTIONS TO ADMINISTRATORS}

\section{Self-Questionnaire}

"You will be given a questionnaire to fill out. Please do not write your name on the OpScan sheet (Show OpScan Sheet). It will be easier, in this way, to give an honest opinion and evaluation of how you feel about yourself.

"About 1,000 adult students in southwest Michigan will respond to these questions. The OpScan sheets will be computer-scored. Your name does not appear on the data sheet: only group findings will be presented in the dissertation."

"Anna K1imes, from Andrews University is making a survey. She is trying to find out what factors are the most vital in your attitude about yourself: the social, the family, the personal, the academic, tec. Please write the same number as on your Nelson-Denny Reading Test. Match the numbers of the SelfQuestionnaire with the numbers of the OpScan sheet. Use a soft lead pencil. Mark one number between 1 and 5 for each item. 
Administer the Nelson-Denny Reading. Test first. Follow the time allotment for each section.

$$
\begin{aligned}
& \text { Vocabulary - } 10 \text { minutes } \\
& \text { Reading Rate - } 1 \text { minute } \\
& \text { Comprehension - } 19 \text { minutes. }
\end{aligned}
$$

The directions for students will suffice the instruction necessary for administration. If there are any further questions as to procedures, pages 6 to 12 of the Manual give explicit instruction. The students need only write some code number like their I.D. number or birth date and indicate the frade levelfreshman, sophomore, etc. The results of the Nelson-Denny Test will be posted in the same area in which the test was taken. 


\section{DIRECTIONS TO ADMINISTRATORS}

\section{The Reading Progress Scale}

The Reading Progress Scale is a very simple device to administer. "You will have seven minutes to read and mark choices on only one page. Use an " $\mathrm{X}$ " or check " $\checkmark$ " to mark your choices. You may use pen or pencil. Write your code number at the top of the sheet."

\begin{tabular}{|l|l|}
\hline 1 & 2 \\
\hline 3 & 4 \\
\hline
\end{tabular}

Show the order of writing the test by using your sheet as an example.

"Write your code number at the top of the sheet. Work as quickly and as accurately as you can. You will have 7 minutes. Begin." 
APPENDIX D

INSTRUCTION SHEETS FOR

ADMINISTRATORS OF INSTRUMENTS 
TABLE 29

WEIGHT, DIRECTION, RANK, AID SIGNIFICANCE OF THE DIMENSIONS OF SELF-COICEPT IN SEPARATINC

INADEQUATE AND ADEQUATE READERS

\begin{tabular}{|c|c|c|c|c|c|c|c|c|c|c|}
\hline \multirow[t]{2}{*}{$\begin{array}{l}\text { Self-Concept } \\
\text { Dimenstons }\end{array}$} & \multicolumn{2}{|c|}{$\stackrel{0}{\frac{\pi}{2}}$} & \multicolumn{2}{|c|}{ 离 } & \multicolumn{2}{|c|}{ 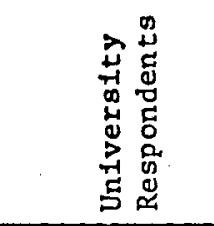 } & \multicolumn{2}{|c|}{ 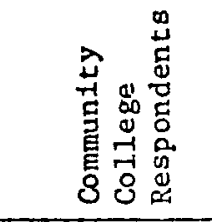 } & \multicolumn{2}{|c|}{ 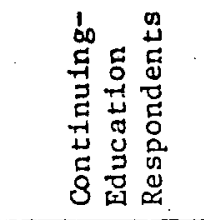 } \\
\hline & Weight & Rank & Weight & Rank & Weight & Rank & Weight & Rank & Weight & Rank \\
\hline Identity & .79 & 1 & .676 & 1 & -.95 & 1 & .50 & 2 & .937 & $1 *$ \\
\hline $\begin{array}{l}\text { Self- } \\
\text { satisfaction }\end{array}$ & -.50 & 3 & .002 & .. 3 & .67 & 3 & -.36 & 3 & -.333 & 2 \\
\hline Behavior & .55 & 2 . & .395 & 2 & .70 & 2 & .85 & 1 & .328 & 3 \\
\hline$\cdot$ & & & & & & & & & & \\
\hline
\end{tabular}


TABLE 30

WEIGIT, RANK, DIRECTION, AND SIGNIFICANCE OF THE COMPONENTS OF SELF-CONCEPT IN SEPARATING

INADEQUATE AND ADEQUATE READERS

\begin{tabular}{|c|c|c|c|c|c|c|c|c|c|c|}
\hline \multirow[t]{2}{*}{$\begin{array}{l}\text { Self-Concept } \\
\text { Component }\end{array}$} & \multicolumn{2}{|c|}{ 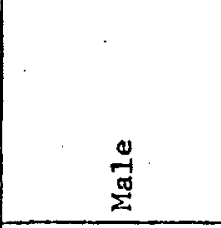 } & \multicolumn{2}{|c|}{ 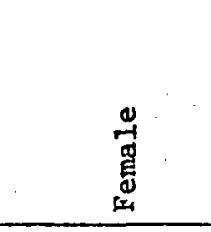 } & \multicolumn{2}{|c|}{ 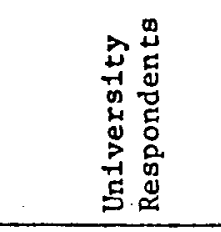 } & \multicolumn{2}{|c|}{ 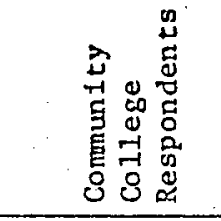 } & \multicolumn{2}{|c|}{ 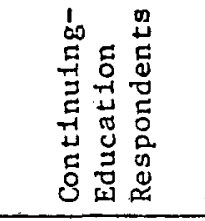 } \\
\hline & Welght & Rank & Weight & Rank & Weight & Rank & Weight & Rank & Weight & Rank \\
\hline Physical & -.51 & 2 & -.36 & 4 & -.41 & 4 & -.43 & $3 *$ & -.48 & $2 *$ \\
\hline $\begin{array}{l}\text { Moral- } \\
\text { Ethical }\end{array}$ & .42 & $4 *$ & .42 & $3 t$ & .35 & 5 & .35 & 4 & .69 & $1 *$ \\
\hline Personal & -.19 & 6 & -.43 & $2 *$ & -.63 & $2 *$ & -.31 & 5 & .21 & 5 \\
\hline Family & .50 & $3 *$ & .31 & 5 & .43 & 3 & -.01 & 6 & .23 & 4 \\
\hline Social & -.25 & 5 & .23 & 6 & .04 & 6 & .60 & $2 *$ & -.05 & 6 \\
\hline Academic & .74 & $1^{*}$ & .81 & $1 *$ & .90 & $1 *$ & .81 & $1 *$ & .44 & 3* \\
\hline
\end{tabular}


TABLE 31

WEIGHT, DIRECTION, RANK, AND SIGNIFICANCE OF THE SULCONPONENTS OF SELF-CONCEPT IN SEPARATING INADEQUATE AITD ADEQQUATE READERS

\begin{tabular}{|c|c|c|c|c|c|c|c|c|c|c|}
\hline \multirow[t]{2}{*}{$\begin{array}{l}\text { Self-Concept } \\
\text { Subcomponents }\end{array}$} & \multicolumn{2}{|c|}{$\stackrel{2}{\frac{\pi}{2}}$} & \multicolumn{2}{|c|}{ 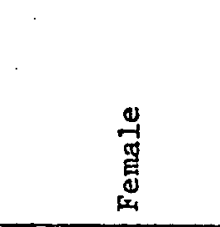 } & \multicolumn{2}{|c|}{ 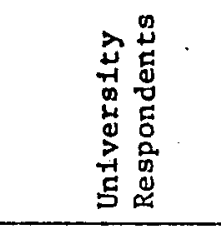 } & \multicolumn{2}{|c|}{ 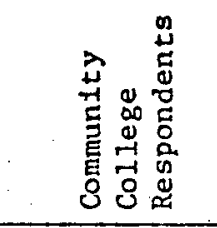 } & \multicolumn{2}{|c|}{ 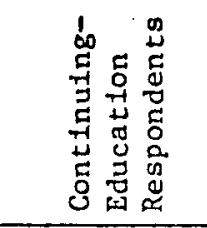 } \\
\hline & Wetght & Rank & Welght & Rank & Weight & Rank & Weight & Rank & Weight & Rank \\
\hline $\begin{array}{l}\text { Physical- } \\
\text { Identity }\end{array}$ & -.218 & 7 & .043 & 16 & -.037 & 15 & -.653 & $1 *$ & .192 & 9 \\
\hline $\begin{array}{l}\text { Moral-ethical } \\
\text { Ident1ty }\end{array}$ & -.008 & 15 & .061 & 13 & -.160 & 8 & .086 & 11 & .540 & 1* \\
\hline $\begin{array}{l}\text { Personal- } \\
\text { Identity }\end{array}$ & .034 & 13 & .052 & 14 & .086 & 13 & .046 & 14 & -.173 & 11 \\
\hline $\begin{array}{l}\text { Family- } \\
\text { identity }\end{array}$ & .412 & $4 *$ & .184 & 9 & -.063 & 14 & .431 & $5 *$ & .404 & $3 *$ \\
\hline $\begin{array}{l}\text { Social- } \\
\text { identity }\end{array}$ & .001 & 16 & -.303 & 5 & -.158 & 9 & .136 & 7. & -.100 & 14 \\
\hline $\begin{array}{l}\text { Physical-self } \\
\text { satisfaction }\end{array}$ & .107 & 10 & -.119 & 11 & -.036 & 16 & .053 & 12 & -.188 & 10 \\
\hline $\begin{array}{l}\text { Moral-ethical } \\
\text { self- } \\
\text { satisfaction }\end{array}$ & .321 & 5 & .263 & 7 & .330 & 5 & .577 & $3 *$ & .090 & 15 \\
\hline $\begin{array}{l}\text { Personal-self } \\
\text { satisfaction }\end{array}$ & -.121 & 9 & -.389 & $3 *$ & -.526 & $2 *$ & -.045 & 15 & .248 & 5 \\
\hline $\begin{array}{l}\text { Family-self- } \\
\text { satisfaction }\end{array}$ & .026 & 14 & -.081 & 12 & .372 & 4 & -.526 & $4 *$ & -.240 & 6 \\
\hline $\begin{array}{l}\text { Soclal-self- } \\
\text { sat1sfaction }\end{array}$ & -.458 & $3^{*}$ & .404 & $2 \star$ & -.124 & 11 & -.102 & 9 & -.117 & 13 \\
\hline $\begin{array}{l}\text { Physical- } \\
\text { behavior }\end{array}$ & -.463 & $2 \star$ & -.320 & 4 & -.377 & 3 & .092 & 10 & -.470 & $2 *$ \\
\hline
\end{tabular}


TABLE 31--Continued

\begin{tabular}{|c|c|c|c|c|c|c|c|c|c|c|}
\hline \multirow[t]{2}{*}{$\begin{array}{l}\text { Self-Concept } \\
\text { Subcomponents }\end{array}$} & \multicolumn{2}{|c|}{$\stackrel{0}{\frac{\pi}{2}}$} & \multicolumn{2}{|c|}{ 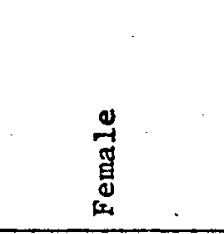 } & \multicolumn{2}{|c|}{ 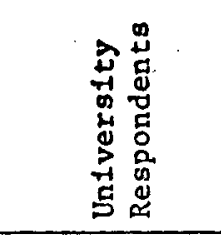 } & \multicolumn{2}{|c|}{ 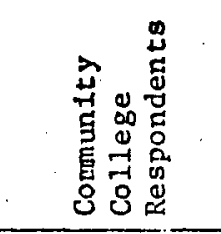 } & \multicolumn{2}{|c|}{ 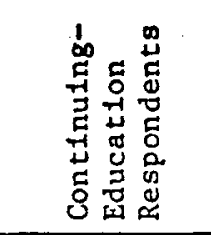 } \\
\hline & Weight & Rank & Weight & Rank & Weight & Rank & Weight & Rank & Weight & Rank \\
\hline $\begin{array}{l}\text { Moral-ethical } \\
\text { behavior }\end{array}$ & .221 & 6 & .046 & 15 & .118 & 12 & -.107 & 8 & .212 & 7 \\
\hline $\begin{array}{l}\text { Personal- } \\
\text { behavior }\end{array}$ & -.069 & 12 & -.174 & 10 & -.204 & 7 & .001 & 16 & .120 & 12 \\
\hline $\begin{array}{l}\text { Family- } \\
\text { behavior }\end{array}$ & .072 & 11 & .199 & 8 & .142 & 10 & .050 & 13 & .030 & 16 \\
\hline $\begin{array}{l}\text { Social- } \\
\text { behavior }\end{array}$ & .114 & 8 & .268 & 6 & .324 & 6 & .246 & 6 & .208 & 8 \\
\hline Academic & .688 & $1^{*}$ & .724 & $1 *$ & .836 & $1^{*}$ & .624 & $2 *$ & .314 & $4 *$ \\
\hline
\end{tabular}


APPENDIX F

DISCRIMINANT ANALYSIS FIGURES 
Figure 1. Discriminant functions of self-concept components separating inadequate and adequate readers. The most important relative weights are shown in descending order of importance from the top.
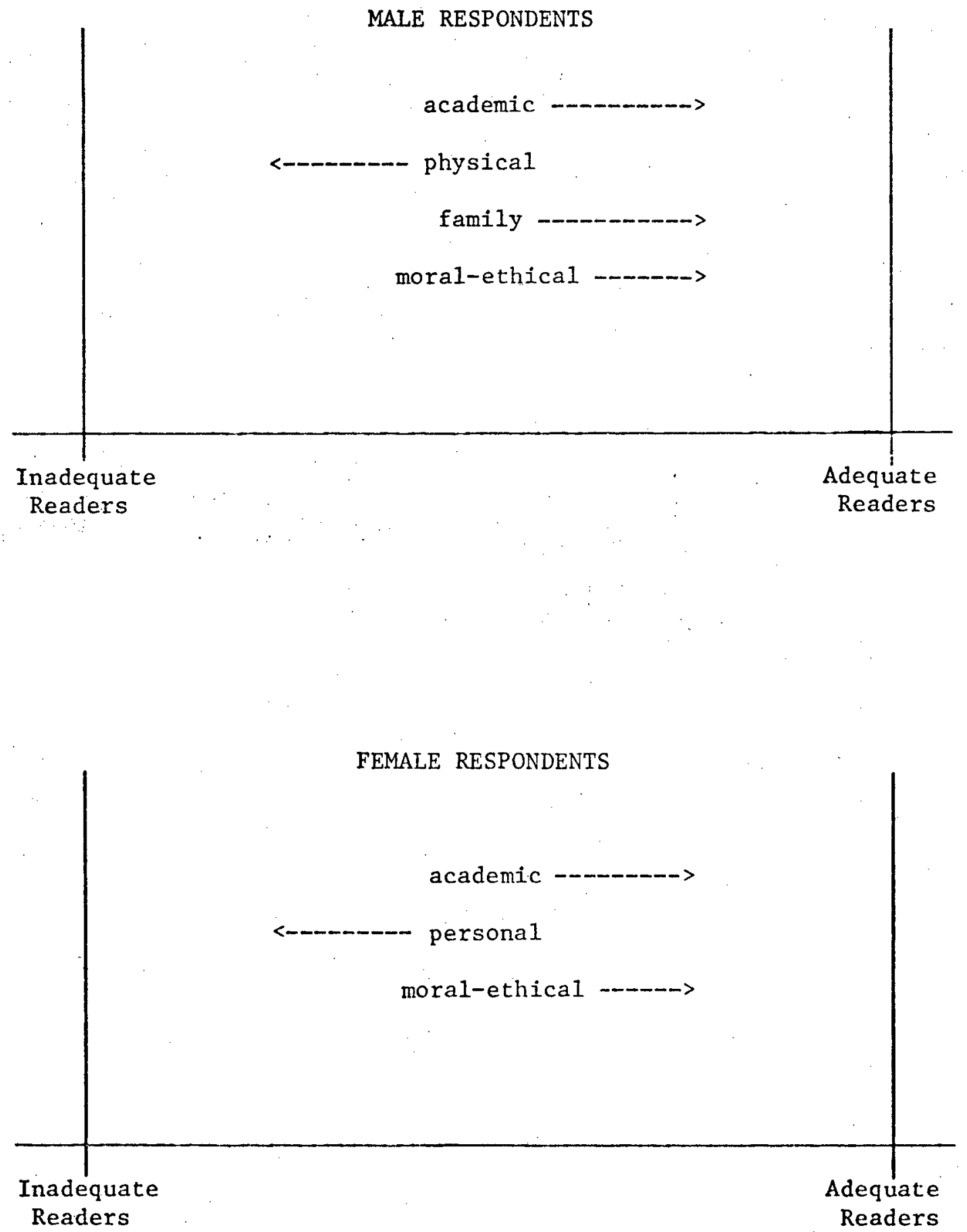
Figure 1-- Continued
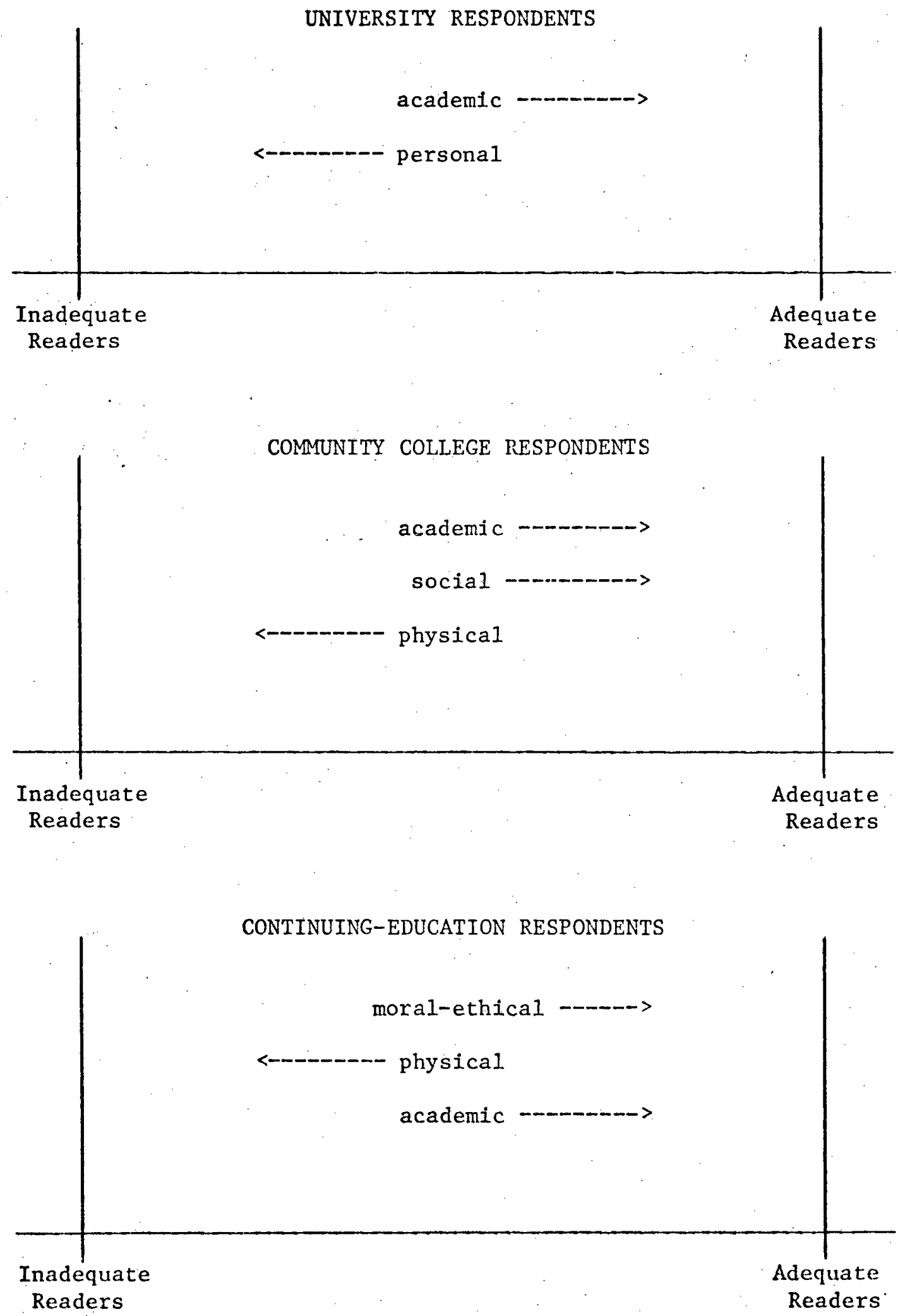
Figure 2. Discriminant functions of self-concept subcomponents separating inadequate and adequate readers.
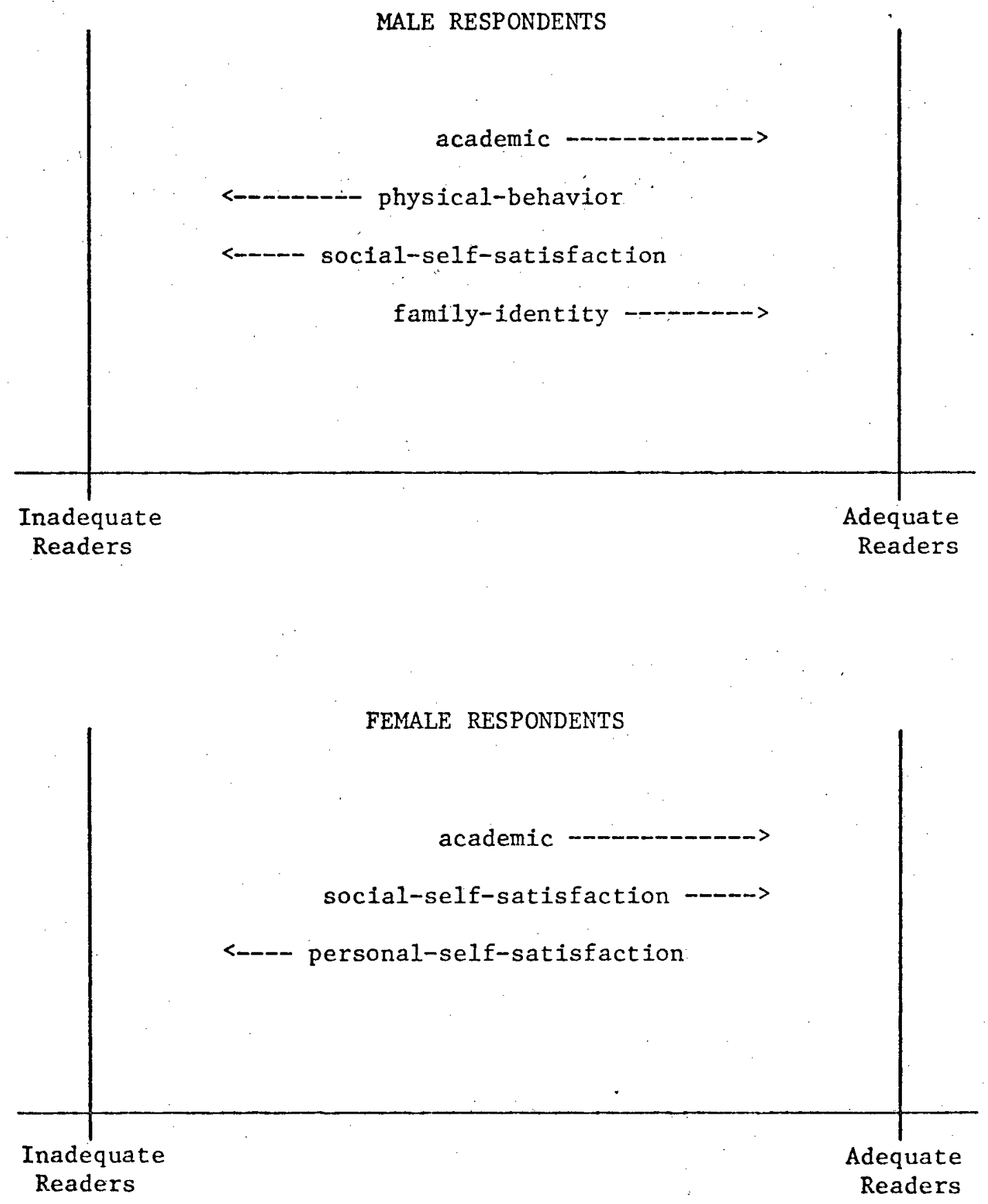
Figure 2--Continued
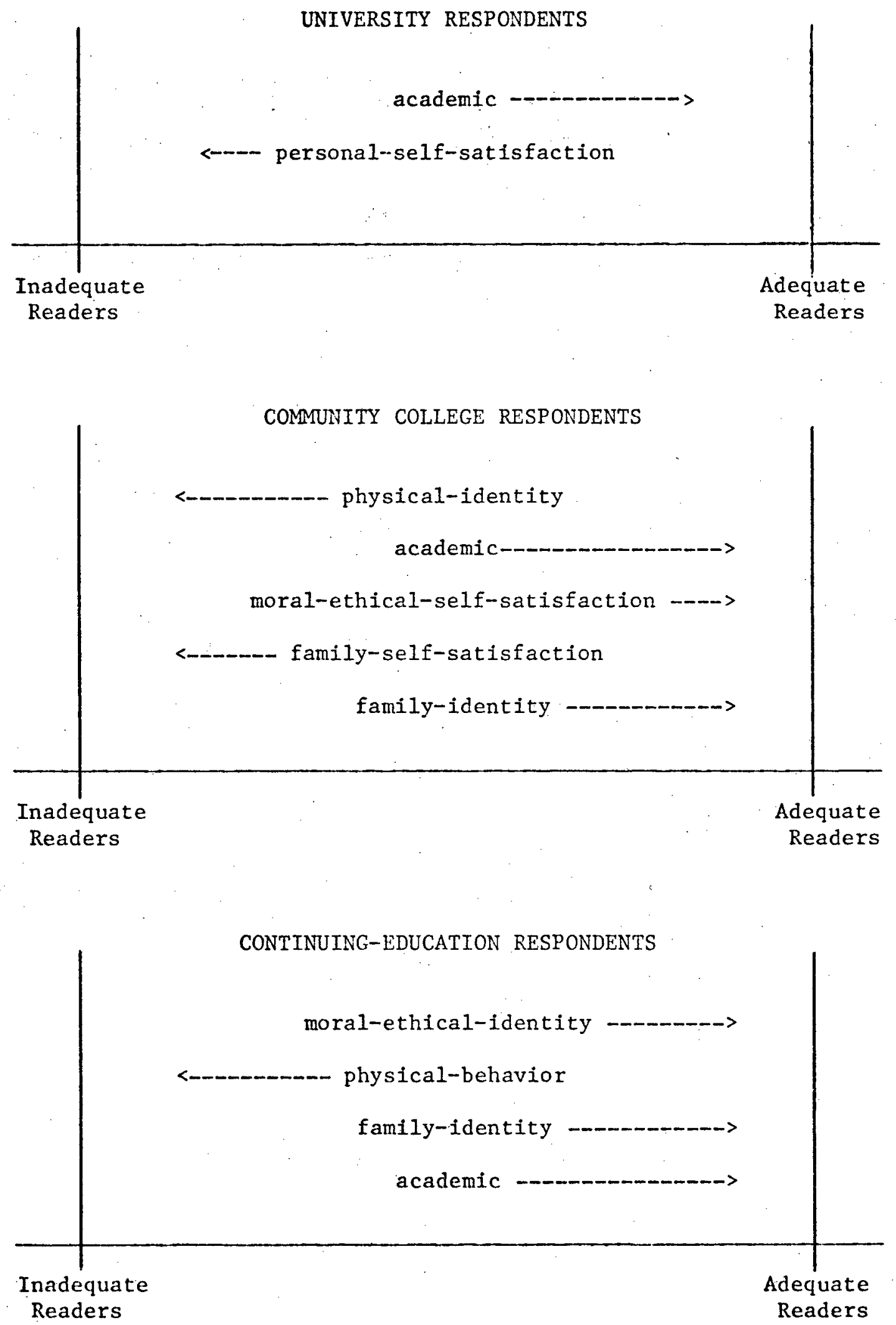


\section{BIBLIOGRAPHY}

Allport, Gordon W. Pattern and Growth in Personality. New York: Holt, Rinehard and Winston, 1961.

- Personality: A Psychological Interpretation. New York: Holt, Rinehard and Winston, 1937.

Allport, G. W., and Odbert, H. S. "Trait-names: A Psycho-Lexical Study." Psychological Monographs, 1936, No. 211.

Anderson, A. W. "Personality Traits in Reading Ability of Western Australian University Freshmen." Journal of Educational Research 54 (February 1961): 234-37.

American College Testing Program, The. The ACT Assessment Counselor's Handbook. Washington, D. C.: The American College Testing Program, Educational Programs and Services, 1976.

Bennett, Virginia D. C. "Development of a Self-Concept Q-Sort for Use with Elementary Age School Children." Journal of School Psychology 3 (Autumn 1964): 19-25.

Berger, E. M. "The Relation between Expressed Acceptance of Self and Expressed Acceptance of Others." Journal of Abnormal and Social Psychology 47 (September 1953): 778-82.

Bills, R. E., Vance, E. L., and McLean, O. S. "An Index of Adjustment and Values." Journal of Consulting Psychology 15 (July 1951): 257-61.

Bledsoe, J. C. "Self-Concepts of Children and Their Intelligence, Achievement, Interests and Anxieties." Childhood Education 43 (March 1967): 436-38.

- "Self-Concept of Children and Their Intelligence, Achievement, Interests and Anxieties." Journal of Individual Psychology 20 (January 1964): 55-58.

Bledsoe, J. C., and Garrison, Earl C. Self-Concept of Elementary School Children in Relation to Their Academic Achievement, Intelligence, Interests and Anxieties. United States Office of Education. Athens: University of Georgia, 1962.

Block, J. The Q-Sort Method in Personality Assessment and Psychiatric Research. Springfield, I11.: Thomas, 1961. 
Block, J., and Thomas, H. "Is Sat1sfaction with Self a Measure of Adjustment?" Journal of Abnormal and Socta1 Psychology 51 (September 1955): 254-59.

Bodwin, F. B. "The Relationship between Immature Self-Concept and Certain Educational Disabilities." East Lansing, Mich.: Michigan State University, 1957.

Bohn, M. J., and Stephenson, R. R. "Vocational Interests and SelfConcept." Newsletter for Research in Psychology 5 (1963): 21-22.

Bond, Guy L., and Tinker, Miles A. Reading Difficulties: Their Diagnosis and Correction. New York: Appelton-CenturyCrofts, 1967.

Borislow, B. "Self-Evaluation and Academic Achievement." Journal of Counseling Psychology 9 (Fa11 1962): 246-54.

Brookover, Wilbur B.; Paterson, Ann; and Thomas, Shailer. SelfConcept of Ability and School Achievement. U.S. Office of Education, Cooperative Research Project No. 845. East Lansing, Mich.: Michigan State University, 1962.

- Self-Concept of Ability and School Achievement II: Improving Achievement through Student's Self-Concept Enhancement. U.S. Office of Education, Cooperative Publications, East Lansing, Mich.: Michigan State University, 1965.

Brown, James I.; Nelson M. J.; and Denny, E. C. Examiner's Manual: The Nelson-Denny Reading Test. Boston: Houghton, Mifflin Company, 1973.

Brownfain, J. "Stability of Self-Concept as a Dimension of Personality." Journal of Abnormal and Social Psychology 47 (November 1952): 596-606.

Brunken, J., and Shen F. "Personality Characteristics of Ineffective, Effective, and Efficient Readers." Personnel and Guidance Journal 44 (April 1966): 837-44.

Buros, Oscar Krisen. The Sixth Mental Measurement Yearbook (Tests in Print). Highland Park, N.J.: The Gryphon Press, 1965.

Busby, David F. "Self-Image and Self-Esteem: A Review of Personality Theories." In Self-Esteem, pp. 53-59. Edited by Craig W. Ellison. Oklahoma City: Southwestern Press, Inc., 1976.

Butler, J., and Haigh, G. "Changes in the Relation between SelfConcepts and Ideal Concepts Consequent upon Client-Centered Counseling.". In Psychotherapy and Personality Change, pp. 55-57. Edited by C. Rogers and B. Dymond. Chicago: Unlversity of Chicago Press, 1954. 
Byrne, D.; Barry J.; and Nelson, D. "Relation of the Revised Repression-Sensitization Scale to Measures of SelfDescription." Psychological Reports 13 (March 1963): 323-34.

Calkins, Keith. 1SAMSIGTST." Andrews University Computing Center, 1977. (Mimeographed)

Campbe11, P. B. "Self-Concept and Academic Achievement in Middle Grade Public School Children." Ph.D. dissertation, Wayne State University, 1965.

Carson, G. L. "The Self-Concept of Welfare Recipients." Personnel and Guidance Journal 45 (January 1967): 424-28.

Carter, T. P. "The Negative Self-Concept of Mexican-American Students." School and Society 96 (March 1968): 217-19.

Carver, Ronald P. The Reading Progress Scale. Kansas City, Mo.: Revrac Publication, 1975.

Clarke, W. E. "The Relationship between College Academic Performance and Expectancies." Ph.D. dissertation, Michigan State University, 1960.

Combs, A. S., and Snygg, D. Individual Behavior, 2nd ed. New York: Harper and Brothers, 1959.

Cooley, William W., and Lohnes, Paul R. Multivariate Procedures for the Behavioral Sciences. New York: John Wiley \& Sons, Inc., 1962.

Cooley, C. H. Human Nature and the Social Order. New York: Charles Scribner's Sons, 1902.

Coopersmith, S. "A Method for Determining Types of Self-Esteem." Journal of Educational Research 59 (January): 87-94.

- The Antecedents of Self-Esteem. San Francisco: Freeman, 1967 .

Corsini, R. J. Standard Adjective Q-Sort. Chicago: Psychometric Affiliates, 1956.

Crafts, Gretchen. "The Effect of Group Counseling in Self-Concept and Reading Improvement of Selected Community College Students." Ph.D. dissertation, Oregon State University, 1975.

Cutick, R. "Self-Evaluation of Capacities as a Function of SelfEsteem and the Characteristics of a Model." Ph.D. disertation, University of Pennsylvania, 1962. 
Davidson, H. H., and Land G. "Children's Perceptions of Their Teachers' Feelings toward Them Related to Self-Perception, School Achlevement and Behavior." Journal of Experimental Education 29 (February 1960): 107-18.

Defrain, David Murray. "The Effects of Self-Concept and Selected Personal and Educational Varlables upon Attrition in a NonCredit College Reading Improvement Program." Ed.D. dissertation, Oklahoma State University, 1970.

Diggory, J. Self-Evaluation: Concepts and Studies. New York: Wiley, 1966.

Duncan, S. "A Reputation Test of Personality Integration." Journal of Personality and Social Psychology 3 (December 1966): $512-24$.

Eag1y, Alice H. "Involvement as a Determinant of Response to Favorable and Unfavorable Information." Journal of Personality and Social Psychology Monograph, November, 1967, 7 (3, Whole No. 643), 1-15.

Ellison, Craig W., ed. Self-Esteem. Oklahoma City: Southwestern Press, Inc., 1976.

Engle, M. "The Stability of the Self-Concept in Adolescence." Journal of Abnormal and Social Psychology 58 (June 1959): $211-15$.

Felch, Glenn W. "Self-Esteem and the Classroom." In Self Esteem, pp. 114-19. Edited by Craig W. Ellison. Oklahoma City: Southwestern Press Inc., 1976.

Felker, Donald W. Building Positive Self-Concepts. Minneapolis, Minn.: Burgess Publishing Company, 1974.

Fennimore, Flora. "The Effect of the Self-Concept on Reading Achievement in a College Reading Clinic." Ed.D. dissertation, Washington State University, 1966.

Fink, M. B. "Self-Concept as It Relates to Academic UnderAchievement." California Journal of Educational Research 13 (January 1962): 57-62.

Fitts, William H. Tennessee Self Concept Scale: Manual. Nashville, Tenn.: Tennessee Counselor Recordings and Tests, 1965. - Tennessee Self Concept Scale: Test Booklet. Nashville, Tenn.: Tennessee Counselor Recordings and Tests, 1964. 
Fitts, William H.; Adams, Jennie L.; Radford, Gladys; Richard, Wayne D.; Thomas, Barbara K; Thomas, Murphy M.; and Thompson, Warren. The Self-Concept and Self-Actualization. Nashville, Tenn.: Dede Wallace Center, 1971.

Fleck, J. Roland. "A Review of the Tennessee Self Concept Scale." In Self-Esteem, pp. 131-34. Edited by Craig W. Ellson. Oklahoma City: Southwestern Press, Inc., 1976.

Ford, Barbara C. "Factors Involved in the Reading Ability of Students in Ontario Colleges of Applied Arts and Technology." Ph.D. dissertation, University of Toronto, 1972.

Frank, Donald. "Self-Concept and Achievement: A Cross-Cultura1 Validation Study in Germany and the United States." Ph.D. dissertation, Western Michigan University, 1976.

Futcher, Wilfred G. A. "TSISAM." Andrews University Computing Center, 1975. (Mimeographed)

- "MUDISC Multivariate Discriminant Analysis." Andrews University Computing Center, 1976. (Mimeographed)

Gergen, Kenneth J. The Concept of Self. New York: Holt, Rinehart and Winston, Inc. 1971.

Gergen, Kenneth J., and Morse, S. "Self-Consistency: Measurement and Validation." Proceedings of the 75th American Psychological Association Convention. 1967.

Gordon, Chad. "Configuration of Content." In The Self in Social Interaction; vol. 1. Edited by Chad Gordon and K. J. Gergen. New York: Wiley, 1968.

Gough, H., and Heibrun, A. B., Jr. The Adjective Check-List Manual. Palo Alto, Califo: Consulting Psychologists, Inc., 1965.

Helper, M. M. "Parental Evaluations of Children and Children's Self-Evaluations." Journal of Abnormal and Social Psychology. 56 (January, 1958): 190-95.

Hoekema, Anthony A. "The Christian Self-Image." In Self-Esteem, pp. 26-29. Edited by Craig W. Ellison. Oklahoma City: Southwestern Press, Inc., 1976.

Holmze, Alma C. "Reading and the Self-Concept." Elementary English 39 (March 1962): 210-15.

Hovland, C., and Janis, I., eds. Personality and Persuasibility. New Haven, Conn.: Yale University Press, 1959.

James, William. Principles of Psychology, 2 vols. New York: Henry Holt, 1890. 
Kelly, George A. "Man's Construction of Human Motives." In Assessment of Human Motives, pp. 34-36. Edited by Gardner LIndsey. New York: Holt, Rinehart \& Winston, Inc., 1958.

Kerlinger, Fred N. Foundations of Behavioral Research, 2nd. ed. New York: Holt, Rinehart and Winston, Inc., 1973.

Kogan, W. S.; Boe, E. E.; and Valentine, B. L. "Changes in the Self-Concept of Unwed Mothers." Journal of Psychology 59 (September 1965): 3-10.

Kuhn, M., and McPartland, C. "An Empirical Investigation of SelfAttitudes." American Sociological Review 19 (January 1954): $58-76$.

Laxer, R. M. "Self-Concept Changes of Depressive Patients in General Hospital Treatment." Joumal of Consulting Psychology 28 (May 1964): 214-19.

Lecky, P. Self-Consistency: A Theory of Personality. New York: Island Press, 1945 .

Lewis, Ruth Watson. "The Relationship of Self-Concept to Reading Achievement." Ed.D. dissertation, University of Virginia, 1972.

Long, B. H., and Henderson, E. H. "Self-Social Concepts of Disadvantaged School Beginners." Journal of Genetic Psychology 113 (January 1968): 41-51.

Lord, Frederic M., and Novick, Melvin R. Statistical Theories of Menta1 Test Scores. New York: Addison and Wesley Publishing Company, 1968.

McCandless, Boyd R. Children Behavior and Development. New York: Ho1t, Rinehart and Winston, Inc., 1967.

McDaniel, E. L. A Manual for the Inferred Self-Concept Scale. Austin, Texas: San Felipe Press, 1969.

McKinley, J. C., and Hathaway, Starke R. Minnesota Multiphasic Personality Inventory. Minneapolis, Minn.: University of Minnesota (copyright, 1943) Psychological Corporation, 1951.

McMillan, Joseph H. "The Changing Self-Image of Black Children: Some Implications for Educational Change." In Self Esteem, pp. 109-13. Edited by Craig W. Ellison. Oklahoma City: Southwestern Press, Inc., 1976.

Misiak, Henryk, and Sexton, Virginia Staudt. History of Psychology: an Overview. New York: Grune \& Stratton, 1966. 
Miskimins, R. W., and Braucht, G. Description of the Self. Fort Collins, Colo.: Rocky Mountain Behavioral Science Institute, 1971.

Moberg, David 0. "Some Soclal Aspects of the Self-Concept." In Self Esteem, pp. 84-92. Edited by Craig W. Ellison. Oklahoma City: Southwestern Press, Inc., 1976.

Morrison, R. L. "Self-Concept Implementation in Occupational Choices." Journal of Counseling Psychology 9 (Fall 1962): 255-60.

Morse, R. N., and Piers, E. V. "Variables Affecting Self-Concept in Black, Disadvantaged Boys." University Park: Pennsylvania State University. n. d. (Mimeographed)

Musik, Sylvia Kaufman. "The Relation of the Self-Concept to Reading." Ph.D. dissertation, United States International University, 1974.

Nocks, J. J., and Bradiey, D. I. "Self-Esteem in an Alcoholic Population." Diseases of the Nervous System 30 (December 1969): 611-17.

Overall, J. E., and Klett, D. J. Applied Multivariate Analysis. New York: McGraw-Hill Company, 1972.

Phillips, E. "Attitudes toward Self and Others: A Brief Questionnaire Report." Joumal of Consulting Psychology 15 (January 1951): 79-81.

Piers, Ellen, and Haris, D. The Piers-Haris Children's Self-Concept Scale. Nashville, Tenn.: Counselor Recordings and Tests, 1969.

Pound, Ronald Edward. "The TSCS and Understanding of Vocational Maturity of Urban Adolescents." Ph.D dissertation, State University of New York at Buffalo, 1975.

Purkey, William W. "Measured and Professed Personality Characteristics of Gifted High School Students and an Analysis of Their Congruence." Journal of Educational Research 60 (November 1966): 99-104.

- Self-Concept of Ability and School Achievement. Englewood Cliffs, N.J.: Prentice Hall, Inc., 1970.

Quandt, Ivan. Self-Concept and Reading. Newark, De1.: International Reading Association, 1972.

Quereshi, M. "The Development of the Bills Adjective Rating Scale" (MARS). Journal of Clinical Psychology 26 (April 1970): 192-96. 
Raimy, V. C. "Self-Reference in Counseling Interviews." Journal of Consulting Psychology 12 (March 1948): 153-63.

Reeder, Thelma Adams. "A Study of Some Relationships between Level of Self-Concept, Academic Achievement and Classroom Adjustment." Ph.D. dissertation, North Texas State College, 1955.

Right to Read Association. Michigan's Right to Read Program. Lansing: Michigan Department of Education, 1975. (Pamphlet)

Robinson, John P., and Shaver, Philip R. Measures of Social Psychological Attitudes. Rev. ed. Ann Arbor, Mich.: The University of lichigan, Institute for Social Research, 1973; 4th printing, 1976.

- "Measures of Social Psychological Attitudes." Appendix $B$ to Measures of Political Attitudes. U. S. Public Health Service and the Inter-University Consortium for Political Research, Publications Division, Institute for Social Research, Ann Arbor: The University of Michigan, 1972.

Rogers, Carl. Client-Centered Therapy. Boston: Houghton Mifflin Co., 1951 .

Rosenberg; M. Society and the Adolescent Self-Image. Princeton, N.J.: Princeton University Press, 1965.

Rosenthal, R., and Jacobson, L. Pygmalion in the Classroom: Teacher Expectation and Pupils Intellectual Development. New York: Holt, Rinehart and Winston, Inc., 1968.

Roth, R. M. "The Role of Self-Concept in Achievement." Journal of Experimental Education 27 (June 1959): 265-81.

Rowe, Margaret Carrie. "Individualized Instruction as a Factor in Self-Concept, Reading and Cognitive Ability Development of Inner-city Pupils." Ph. D. dissertation, University of Michigan, 1975.

Secord, P., and Blackman, C. Social Psychology. New York: McGrawHill and Company, Ltd., 1964.

Schwartz, M., and Tangri, Sandra S. "A Note on Self-Concept as Insulator against Delinquency." American Sociological Review 30 (December 1965): 922-26.

Shaver, Phillip R. "Measurement of Self-Esteem and Related Constructs." In Measures of Social Psychological Attitudes. Rev. ed., pp. 45-168. Ann Arbor: The University of Michigan, Institute for Social Research, 1973; 4th printing, 1976.

Shat, M. C., and Alves, G. J. "The Self-Concept of Bright Academic Underachievers: Continued." Personnel and Guldance 42

(November 1963): 401-3. 
Sherwood, J. J. "Self-Ident1ty and Self-Actualization: A Theory and Research." Ed.D. dissertation, University of Michigan, 1962.

Shostrum, Everett L. "Self-Esteem and Self-Actualization." In Self Esteem, pp. 70-79. Edited by Craig W. Ellison. Oklahoma City: Southwestern Press, Inc., 1976.

Shrauger, J., and Rosenberg, S. "Self-Esteem and the Effects of Success and Failure Feedback on Performance." Journal of Personality 38 (September 1970): 404-17.

Simmons, R. K., and Lamberth, E. L. "Q-Sort Technique as a Means of Determining the Relation of Family Structure to Self-Concept." Marriage and Family Living 23 (May 1960): 183-84.

Simpson, Wessylyne Alford. "Self-Concept and Career Choice among Black Women." Ed.D. dissertation, Oklahoma State University, 1975.

Snygg D., and Combs, A. W. Individual Behavior: A New Frame of Reference for Psychology. New York: Harper \& Row, 1949.

Staines, J. W. "The Self-Picture as a Factor in the Classroom." British Journal of Educational Psychology 28 (June 1958): 97-111.

Tatsuoka, Marice M. Multivariate Analysis. New York: John Wiley \& Sons, Inc., 1971 .

Taylor, D. "Changes in the Self-Concept-without Psycho-Therapy." Journal of Consulting Psychology 19 (June 1955): 205-09.

Torgerson, Warren S. Theory and Methods of Scaling. New York: John Wiley \& Sons, Inc., 1958.

Vacchiano, R. B., and Strauss, P. S. "The Construct Validity of the Tennessee Self Concept Scale." Journal of Clinical Psychology 24 (1968): 323-26.

V1lhotti, Anthony Joseph. "A Study of the Relationships between Components of the Self-Concept and Specific Reading Skills in Seventh-Grade Pupils." Ed.D. dissertation, Fordham Unfversity, 1973.

Webb, W. "Self-Evaluations, Group Evaluations, and Objective Measures." Journal of Consulting Psychology 19 (June 1955): 210-12.

Wells, Edward L, and Marwell, Gerald. Self-Esteem: Its Conceptualization and Measurement. Beverly Hills, Calif.: Sage Publications, Inc., 1976. 
Wiersma, William. Research Methods In Education. Itasca, I11.: F. E. Peacock Pub1ishers, Inc., 1975.

Williams, John Robert. "A Comparison of the Self-Concepts of Alcoholic and Non-Alcoholic Males of Indian and Non-Indian Ancestry in Terms of Scores on the Tennessee Self Concept Scale." Ed.D. dissertation, University of South Dakota, 1975.

Wise, F. Franklin. "Some Implications of Wesley Theology." In Se1f-Esteem, pp. 40-49. Edited by Craig W. Ellison. Oklahoma City: Southwestern Press, Inc., 1976.

Wylie, Ruth C. The Self-Concept: A Critical Survey of Pertinent Research Literature. Lincoln: University of Nebraska Press, 1961.

- The Self Concept: A Review of Methodological Considerations and Measuring Instruments. Rev. ed., vol. 1. Lincoln: University of Nebraska Press, 1974.

Zander, A., and Thomas, E. The Validity of a Measure of Ego Strength. University of Michigan, Institute for Social Research, 1960. (Pamphlet) 
VITA OF ANNA HOMENCHUK KLIMES

Date of Birth: February 2, 1929

Place of Birth: Rhein, Saskatchewan, Canada

EDUCATION

Diploma, 1948, King Edward High School, Vancouver, British Columbia Matriculation, 1949, Canadian Union College, College Heights, Alberta

Diploma in Education, 1950, British Columbia Normal School, Vancouver, British Columbia

Teacher Certificate Course, 1952, 1953, Kingsway College, Oshawa, Ontario

B. Sc. degree, 1957, Walla Walla College, College Place, Washington, Majors in Secondary Education and Home Economics

M. A. in education degree, 1964, Indiana University, Bloomington, Indiana, Major in linguistics and teaching English as a foreign language

Ed. D. degree, 1977, Andrews University, Berrien Springs, Michigan, Concentration in Educational Psychology and Counseling, Cognate in Reading Instruction

PROFESSIONAL EXPERIENCE

Elementary Schools in British Columbia, 1950-54, Teacher

Elementary School and Kindergarten, Far Eastern Academy, Singapore, 1957-59, Teacher

Indonesian Union College, Bandung, Indonesia, 1959, Visiting Instructor

Elementary Schoo1, Korea Union Mission, Seoul, Korea, 1959-65, Teacher

Korea Union Ccllege, Seoul, Korea, 1965-69, Assistant Professor of English as a Foreign Language

Intensive English Language Institute, Seoul, Korea, 1968-69, Director

Saniku Gakuin College, Chiba-Ken, Japan, 1969-1972, Associate Professor of English as a Foreign Language; 1973, Professor of English as a Foreign Language

Intensive English Language Institute, Chiba-Ken, Japan, 1973, Director

Andrews University, Department of Education, Berrien Springs, Michigan, 1973 to Present, Contract Instructor in Reading Skills for College Students and Reading Instruction 
